\title{
Map and Database of Quaternary Faults and Lineaments in Brazil
}

\author{
By Allaoua Saadi, Michael N. Machette, Kathleen M. Haller, Richard L. Dart, \\ Lee-Ann Bradley, and Angela Maria P.D. de Souza
}

Open-File Report 02-230

2002

This report is preliminary and has not been reviewed for conformity with U.S. Geological Survey editorial standards nor with the North American Stratigraphic Code. Any use of trade, firm, or product names is for descriptive purposes only and does not imply endorsement by the U.S. Government.

\section{U.S. Department of the Interior \\ U.S. Geological Survey}

Denver, Colorado 


\title{
Map and Database of Quaternary Faults and Lineaments in Brazil
}

\section{A project of the International Lithosphere Program Task Group II-2, Major Active Faults of the World}

\author{
Data and map compiled by \\ ${ }^{1}$ ALLAOUA SAADI ${ }^{2}$ MICHAEL N. MACHETTE, ${ }^{2}$ KATHLEEN M. HALLER, \\ ${ }^{2}$ RICHARD L. DART, ${ }^{2}$ LEE-ANN BRADLEY, AND ${ }^{1}$ ANGELA MARIA P.D. DE SOUZA \\ ${ }^{1}$ Centro de Pesquisa Prof. Manoel Teixeira da Costa \\ Instituto de Geociencias \\ Universidade Federal de Minas Gerais \\ Av. Antonio Carlos, 6627 \\ 31270-901 Belo Horizonte-MG, Brazil \\ ${ }^{2}$ U.S. Geological Survey \\ Central Region Geologic Hazards Team \\ MS 966, P.O. Box 25046 \\ Denver, Colorado, 80225 USA \\ Regional Coordinator for Central America \\ CARLOS COSTA \\ Universidad Nacional de San Luis \\ Departmento de Geologia \\ Casilla de Correo 320 \\ San Luis 5700, Argentina \\ International Lithosphere Program \\ Task Group II-2 Co-Chairman (Western Hemisphere) \\ MICHAEL MACHETTE \\ U.S. Geological Survey \\ Central Region Geologic Hazards Team \\ MS 966, P.O. Box 25046 \\ Denver, Colorado, 80225 USA
}




\section{TABLE OF CONTENTS}

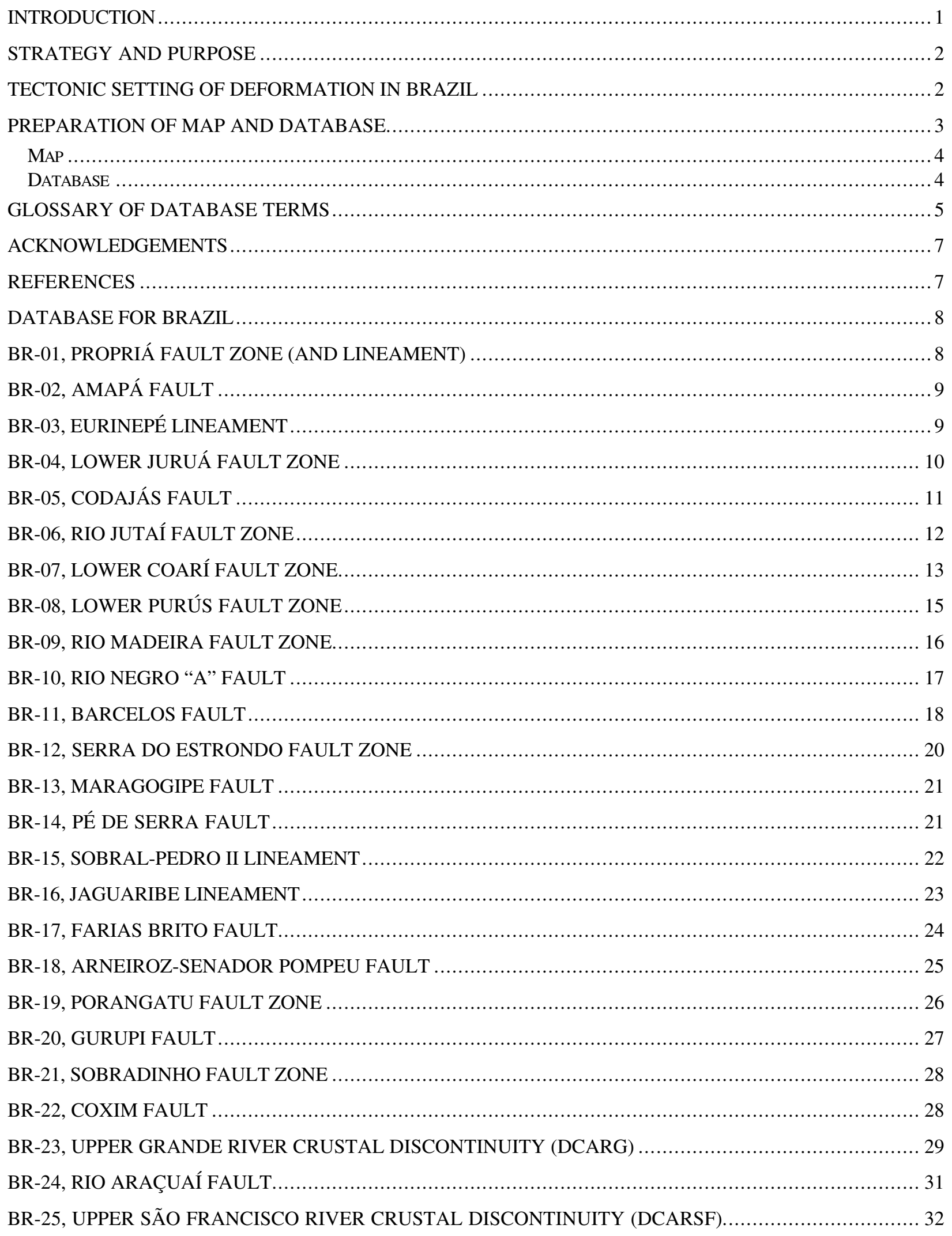




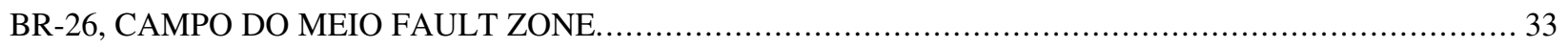

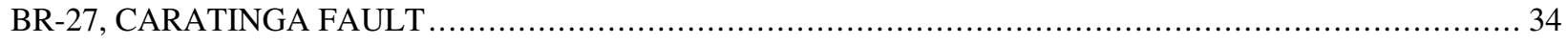

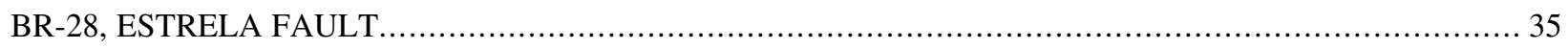

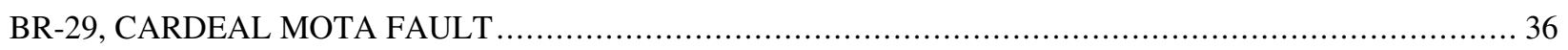

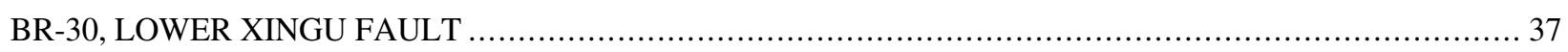

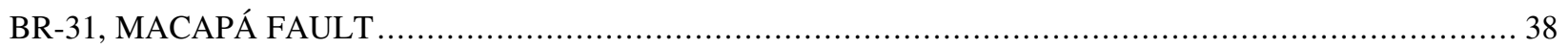

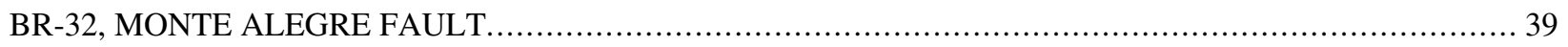

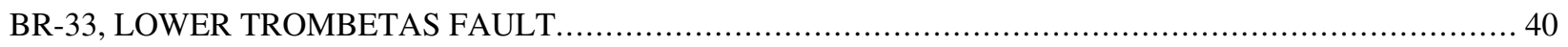

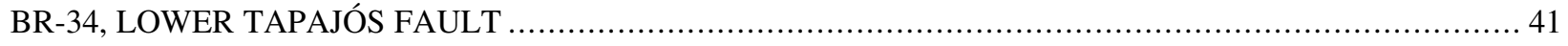

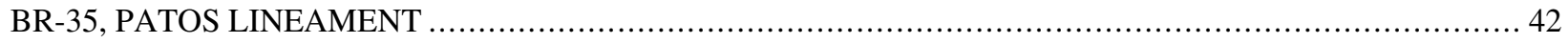

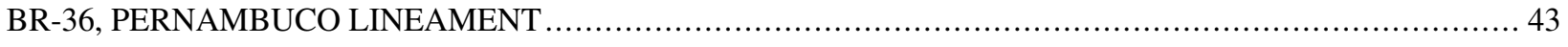

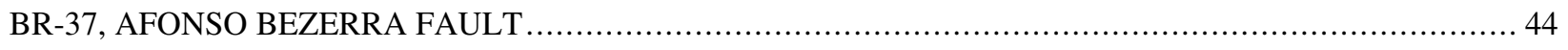

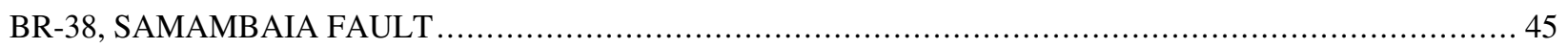

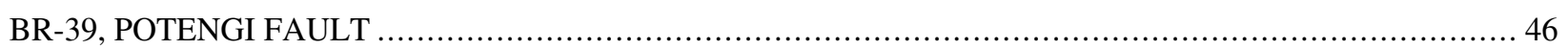

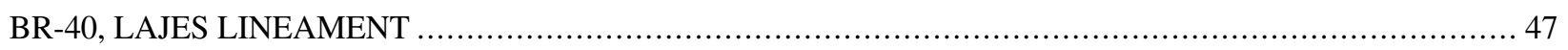

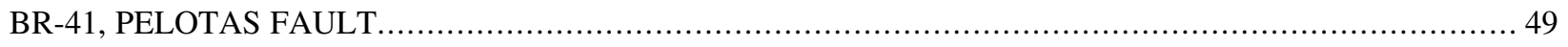

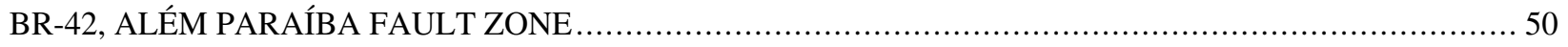

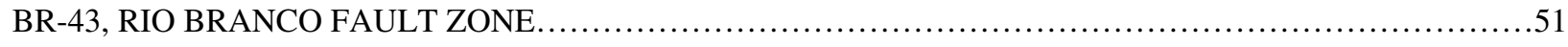

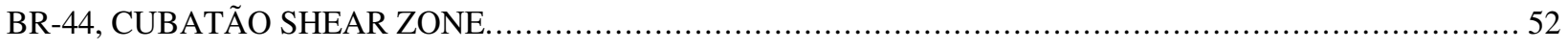

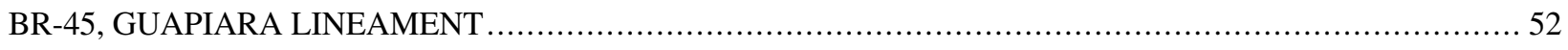

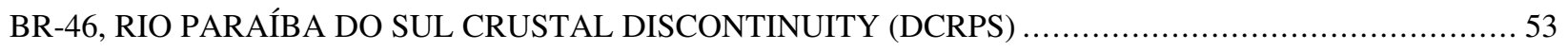

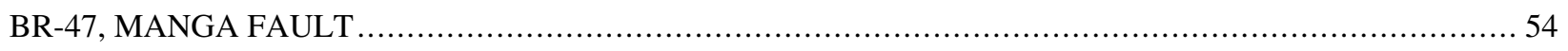

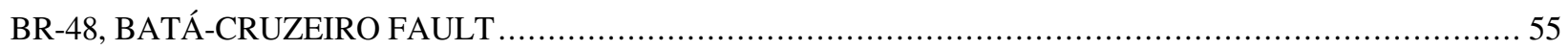

\section{LIST OF TABLES}

Page

TABLE 1. QUATERNARY FAULTS AND LINEAMENTS IN BRAZIL .................................... 57 


\section{INTRODUCTION}

The U.S. Geological Survey (USGS) is assisting in the compilation of a series of digital maps of Quaternary faults and folds in Western Hemisphere countries as part of the International Lithosphere Program's (ILP) Task Group II-2 "World Map of Major Active Faults." The maps from this project show the locations, ages, and activity rates of major earthquake-related features such as faults, lineaments (in Brazil), and fault-related folds. They are accompanied by databases that describe these features and document current information on their activity in the Quaternary. The project is a key part of the Global Seismic Hazards Assessment Program (ILP Task Group II-0) for the International Decade for Natural Hazard Disaster Reduction.

The project is sponsored by the International Lithosphere Program and funded by the USGS's National Earthquake Hazards Reduction Program. The primary elements of the project are general supervision and interpretation of geologic/tectonic information (Michael N. Machette, Project Chief), data compilation and entry for fault catalog (all personnel), database design and management (Kathleen M. Haller), and digitization and editing of fault and fold traces (Richard L. Dart) in ${ }^{\dagger}$ ARCINFO. For the compilation of data, we engaged experts in Quaternary faulting, neotectonics, paleoseismology, and seismology. These experts are the primary authors of this report, and questions about individual fault descriptions should be directed to them. Questions about the project, its status, and the GIS map should go to the USGS authors.

Prior to initiating this project, no modern or digital map of active or Quaternary faults existed for Brazil or any other country within South America, even though understanding the extent and character of active and older Quaternary faults are critical elements of seismic hazards analysis. Creation of this map and the accompanying database will help extend the relatively short record of instrumental and felt seismicity in Brazil by creating a Quaternary record of surface deformation associated with large $(M>6.5)$ earthquakes.

Although basic fault data are available for most of the country, the degree of completeness varies greatly and often is a function of the degree of remoteness, vegetation cover, and age and type of the underlying rock. Most of the information for Brazil is from classic "neotectonic studies" that analyze structural control of drainage patterns and satellite imagery. One striking example of this is in the Amazon region, where many of the mapped structural features seem to control the course of the Amazon and its major tributaries. This map is different from many of the other ones for South America in that it also includes information on lineaments in pre-Cenozoic rock that may be associated with Quaternary faulting. Only a few faults have been the subject of recent investigations involving modern techniques, especially where young material (late Quatenary or Holocene) is suspected of being deformed. Other regions and faults have been studied in some detail, usually in association with concerns about hazards to urban areas or the safety of critical facilities such as lifelines, oil-and-gas pipelines, or power-generating facilities. Considerable effort was required from the primary authors in order to compile information from a wide variety of sources and insure that the national product is up to date and provides fairly uniform coverage for the entire country. Little is known in a collective sense about the overall rates of fault activity and fault chronology-information that is difficult to acquire but critical to seismic hazard assessments. Nevertheless, the general state of knowledge for faulting in Brazil is probably best described as being of a reconnaissance nature. Hopefully, additional paleoseismic studies will help augment this map and database.

Several papers have appeared recently that suggest local evidence for Quaternary faulting, although alternate origins are possible for some of the relations shown in the papers (such as landsliding, fluvial cut and fill stratigraphy, etc.). However, there is a growing body of evidence that some of the seemingly ancient faults in Brazil are being reactivated in the current stress regime. Although not included in this compilation, the readers should consult the recent paper by Riccomini and Assumpção (1999, and referencesthere in) for evidence of additional young faulting that is not described herein. There have been no reports of surface faulting in historic times in Brazil, nor earthquakes in the upper crust $(<25 \mathrm{~km})$ of sufficient magnitude (ca. M 6.5$)$ that would likely produce surface

\footnotetext{
${ }^{\dagger}$ Any use of trade names (such as this and others in the report) does not imply endorsement by the U.S. Geological Survey.
} 
rupturing. Nevertheless, there have been at least 11 instances of surface faulting in stable continental regions that are marked by low rates of seismicity (Crone and others, 1997), so surface rupturing in Brazil would not be unexpected.

\section{STRATEGY AND PURPOSE}

For the map of Brazil, we relied on known, productive experts with strong local or regional knowledge of Brazil who were willing to participate in this international project. Given the limited time to produce the map, the project was restricted to compilation of just those elements needed for ILP's Global Seismic Hazards Assessment Program (see database). We anticipate that the project will point out the shortcomings of past and current research on Quaternary faulting in Brazil in terms of quantity, quality, scope, and regional coverage and should help promote new efforts to collect paleoseismological data in previously neglected or known critical areas.

In the past, seismicity has been used to define some potentially active faults, especially along active plate margins. However, some recent faulting events in the Western Hemisphere have shown that much of the faulting away from active plate margins occurs along faults with no significant level of seismicity and that only a fraction of active faults are characterized by ongoing seismicity. Brazil represents a region of continental crust that is relatively stable and has strain rates that are believed to be low. Many of the faults in Brazil that are considered to have evidence for Quaternary movement are related to long-lived linements or crustal discontinuities (shear zones) of Precambrian or Paleozoic heritage. However, this evidence is largely geomorphological and not structural or paleoseismological, and thus evidence for movement on these faults are considerably less robust than in more active regions, such as Venezuela or Colombia. The information on Quaternary faulting included within this database should help extend the modern (past several hundred years) record of seismicity into prehistoric time, and allow better assessments of active and potentially active faults in Brazil and other Western Hemisphere countries.

\section{TECTONIC SETTING OF DEFORMATION IN BRAZIL}

Most of the seemingly young structures in Brazil have an ancient heritage, often starting in the Precambrian. For this reason it is worthwhile reviewing, in a general sense, the tectonic history of Brazil with a focus on the neotectontic aspects. The tectonic setting of recent movements in the Brazilian Platform is characterized by the spatial distribution of two types of main Precambrian geotectonic units (Almeida and others, 1981): (A) cratonic blocks (or nuclei) comprised of Archean granitic-gneissic complexes (mainly Amazonian and São Francisco Cratons), surrounded by (B) collisional sutures acting as weakness zones all through the regional geologic evolution. During the Precambrian, the mobility along these sutures through successive rifting and orogenic processes resulted in the development of granulitic belts, green-schist bundles, and volcaniclastic metamorphized and folded bundles. The main orogenic cycles are thought to be the Transamazonian (2.1 to $1.9 \mathrm{Ga}$ ) and the Brazilian (750 to $550 \mathrm{Ma})$. These orogenies gave rise to the Borborema Fold Belt (northeast trend) in northeast Brazil; the Mantiqueira Fold Belt (NE to $\mathrm{N}$ trend) in southeast Brazil, and the Tocantins Fold Belt (NNW to N trend) in the central region of Brazil. The main axes of tectonic reactivation have been along structures linked to the last orogeny, to the master geosutures, amd to local anisotropies.

Another master player in the Precambrian tectonic framework is the Transbrazilian Lineament (Schobbenhaus and others, 1975). This lineament is envisaged as a $\mathrm{N} 45^{\circ} \mathrm{E}$-trending shear zone that extends $2,700 \mathrm{~km}$ across Brazilian territory, from the Ceará State in the northeast (continuing into the Kandi-Hoggar fault in Africa) to the Mato Grosso do Sul State in the southwest (and connecting with some lineaments in Paraguay and Argentina). Such a structure has controlled the differentiation between "two Geotectonic Brazils" (Brito Neves, 1991): the PreBrazilian Domain (Amazonic Region) is basically craton-derived, whereas the Brazilian Domain (Extra Amazonian Region) has been defined as "an assorted mixture of different orogenies in the modern sense of this term" (Brito Neves, 1991). 
The marginal arcs of the intracratonic sedimentary basins were developed during Silurian-Devonian time: these areas correspond to the Amazonian (all the Amazonian region), Paranaiba (northeastern Brazil) and Paraná (southern Brazil extending into Argentina and Uruguay) basins, where 4,000-5,000 m of marine and continental deposits (including glaciogenic facies) are still preserved. The shapes of the Paranaiba and Paraná basins seem to be controlled by the NE- and NNW- to N-trending Precambrian structures. The E-W elongated Amazonian basin might reflect a "reactivation related with the Andean Orogen evolution" (Petri and Fúlfaro, 1983) without clear evidence of influence from the Precambrian structures. In all these basins the sedimentary record started as a wide transgression in the Late Carboniferous with a final uplift by latest Permian time.

The beginning of the Mesozoic in Brazil represents, from a tectonic point of view, a continuation of the conditions prevailing during the Paleozoic. This is why it was called the "Intracratonic Cycle" (Sampaio and Northfleet, 1973) and, until Middle Jurassic time, this region was dominated by a tectonic quiescence marked by widespread erosion and continental sedimentation.

During Late Jurassic, the Gondwana break-up resulted in quite widespread fissural magmatism, which continued during the Cretaceous with the South Atlantic Ocean aperture. During such an event, so called "South Atlantian", basaltic dykes were emplaced with a preferred NW direction, independent from Precambrian structures. The faults controlling the new grabens (9,000 m-thick fill) and the marginal basins (1,000-2,000 m-thick fill) are parallel to the Brazilian structures, except in northeast Brazil, where E-trending shear zones had a strong influence, showing continuity in the oceanic fracture zones as the Patos and Pernambuco lineaments (Schobbenhaus and others 1981). Conversely, in the southeast and south of Brazil there seems to be a sort of continuity between the E-trending oceanic lineaments and the NW-trending continental linear features, developed during the evolution of the intracratonic basins. However there is no convincing evidence for this interpretation, as yet.

During the transition between Cretaceous-Tertiary time, an important alkaline magmatic event took place, quite well represented by the Italia and Passa Quatro massifs in the southeast part of Brazil. This process was followed by continental rifting, which in turn gave rise to the ENE-trending "Serra do Mar Rift System" (Almeida, 1976). The "Serra de Mantiqueira" (at the southern end of this rift) was uplifted about 2,000 $\mathrm{m}$ at this time. Meanwhile, at the adjacent oceanic margin (Santos Basin), there was about 5,000 $\mathrm{m}$ of Cenozoic vertical displacement.

Between lower Miocene and Pliocene time some isolated tectonic basins developed due to reactivation of Brazilian structures (Saadi, 1993). Recent apatite fission-track dating suggests increase in the rate of crustal uplift after the Pliocene (Hackspacker Team, personal communication).

Presently, the Brazilian Platform is located between the Atlantic passive margin to the east, the very distant Andean trench to the west, and the Caribbean trench and plate boundary to the north. As a result of this setting, the continental stresss result in E-W to WNW-ESE shortening along the Atlantic coast and predominantly NW-SE shortening within the intraplate domain. However, we must also mention the probable influence of an extensional regime associated to the Continental Platform, which is characterized by an extensional axis parallel to the eastern coastline of Brazil.

\section{PREPARATION OF MAP AND DATABASE}

This compilation shows evidence for activity on Quaternary faults and lineaments in Brazil. The data were compiled during 1996-97 from the available published literature (through 1997) and recent geological investigations, and from interpretation of imagery by the senior author, Allaoua Saadi (Universidade Federal de Minas Gerais, Brazil). Michael Machette edited most of the text (which was translated from Portuguese by the senior author) and map data and provided guidance for the project under the International Lithosphere Program's Task Group II-2 "Major Active Faults and Folds of the World," for which he is the Co-chairman (Western Hemisphere). The surface traces of the Quaternary faults and folds were compiled on a topographic base map at a scale of 1:1,000,000 by Allaoua Saadi and digitized using MicroStation software by Angela Maria P.D. de Souza (Universidade Federal de Minas Gerais). 
Richard Dart used GIS (Geographic Information System) technology to translate the MicroStation map and to produce the fault and lineament maps. The traces of Quaternary faults and lineaments were refit to the base map, attributed for age, sense of slip, and line type (continuous, discontinuous, and concealed or inferred), and reprojected using a Mercator projection. The maps were prepared with ARC/INFO version 7.2.1 running under Solaris version 2.6 on a Unix workstation. The GIS data is scale independent but should not be used at scales greater (more detailed) than 1:500,000. Data for the fault endpoints, length, and average strike were generated from the ARC/INFO files.

The base-map information was taken from the Digital Chart of the World, which was created for use with ARC/INFO (copyright 1993 by the Environmental Systems Research Institute, Inc.). The Digital Chart of the World was compiled at a scale of 1:1,000,000, thus the geographic data is quite compact at the printed scale of the map $(1: 6,000,000)$. It was originally developed for the United States Defense Mapping Agency (DMA) and is primarily derived from the DMA Operational Navigation Chart (ONC) Series.

\section{MAP}

The map of Quaternary faults and lineaments of Brazil was compiled and digitized from regional base maps at 1:1,000,000 scale. This scale allows output as a single-country map (1:6,000,000 scale) or provincial and regional maps (about 1:1,000,000 or 1:2,000,000 scale) while retaining all significant digital information. In addition to fault type and location, the map shows time of most recent movement and estimates of slip rate (as a proxy for fault activity). Although as many as five categories of Quaternary faults can be depicted on the Western Hemisphere maps, only two categories were used in Brazil:

Holocene and latest Pleistocene $(<15,000$ years or $<15 \mathrm{ka})$,

Quaternary $(<1,600,000$ years or $<1.6 \mathrm{Ma})$.

There are no known cases of historic faulting in Brazil, which generally encompasses the past 200-300 years. Categories for differentiating late Quaternary $(<130 \mathrm{ka})$ and late and middle Quaternary $(<750 \mathrm{ka})$ ruptures also were not used owing to the general lack of stratigraphic and chronological control needed to make these age differentiations. Nevertheless, this categorical time scheme allows some flexibility in reporting between countries owing to the differing levels of investigation and abilities to date prehistoric faulting.

Three ranges of slip rates can be depicted by differing lines thicknesses on the map in order to differentiate known rates of fault activity:

$>5 \mathrm{~mm} / \mathrm{yr}$-Plate-boundary faults and subduction zones,

1-5 mm/yr - Lesser strike-slip and major extensional faults,

$<1 \mathrm{~mm} / \mathrm{yr}-$ Most extensional and intraplate faults.

There are no published slip-rate data available for faults in Brazil. However, based on its tectonic setting (stable continential region), we have given all structures (faults and lineaments) an "unknown, probably $<1 \mathrm{~mm}$ " slip rate and drawn them with the $<1-\mathrm{mm} / \mathrm{yr}$ line thickness. Actual slip rates may be even slow, perhaps $<0.2 \mathrm{~mm} / \mathrm{yr}$ as we have found in other stable continental regions.

\section{DATABASE}

The purpose of the database is to provide large quantities of fault data that can be readily accessed using a variety of search parameters. For this database, we anticipate that the user would want search-and-retrieve capabilities from a personal computer. The user may want to sort the data by such parameters as fault name, time of most recent movement (one of three categories), slip rate (one of three categories), sense of movement, or by multiple parameters. Each of the fault descriptions is referenced separately, which is a requirement of the computer database. The term "Anais" refers to "Proceedings"; as such these references are typically abstracts or short papers. 
The process of data compilation starts with data acquisition and synthesis. In the case of faults, the compiler must determine if the structure is a simple one, or if it qualifies as having sections (increasing complexity of geometry or fault history). Then using the appropriate form, the compiler tabulates information on the fault's parameters. The forms were built in Microsoft Word for the Macintosh and PC Windows.

After this report is released, we will incorporate suggested changes and additions; then import the data to the computer database. Each of the fields is a potential search object. The use of a computer database program allows us to custom format the reporting of data and to collapse unused fields or notes. The basic fields are restricted to 256 characters, but we use the note option for more explanatory information (shown under comments in this report). References are shown in the languague of their publication.

The fault and lineament data will be released in several forms. This open-file report constitutes a traditional hard-copy catalog (database and map) for Brazil. The Brazilian data will become part of a larger relational computer database for the Western Hemisphere that should be available on the World Wide Web (WWW). This interactive WWW product allows the user to browse, sort, and print the data. However, we do not anticipate allowing the database to be altered using only the run-time WWW version of the database program.

\section{GLOSSARY OF DATABASE TERMS}

The following glossary is adapted for South American countries. Specialized fields provide data, most of which will be in searchable fields when the computer database is released. In addition to the searchable fields, more detailed information is provided in the "Comments" section that follows some fields. If a field is empty or has been deleted, no pertinent information was found in the published literature. The following description provides definitions of fields (in alphabetic order) and indicates where various information, if known, can be found. Citations of references are in a traditional (USGS) format, although foreign language citations are as provided by the compilers.

Average dip General down-dip direction of the structure, where known.

Average strike Length-weighted average strike (azimuth) of the structure in degrees. The reported azimuth values are confined to the northern hemisphere of the compass (i.e., $0^{\circ}$ to $90^{\circ}$ are $\mathrm{N}$ to $\mathrm{E}$, and $0^{\circ}$ to -90 are $\mathrm{N}$ to $\mathrm{W}$ ).

Compiler, affiliation and date of compilation The name and affiliation of the person(s) primarily responsible for compilation or revision of data presented for the structure. Also shown is the date when data were compiled for this project (e.g., September 1997).

End Points These are the latitude and longitude coordinates (in degrees and minutes) for the end points of the structure.

Fault or lineament name (see Name)

Fault of lineament number (see Number)

Fault geometry This includes geographic information pertinent to the fault or faults being described. The data include length, average strike, average dip, and sense of movement.

Geomorphic expression General description of the structure's geomorphic expression including information on the presence or absence of fault scarps, offset streams, monoclines, shutter ridges, associated landslides, etc.

Historical surface faulting When the timing of most recent movement is historic (none in Brazil), then this field(s) describes evidence for surface faulting associated with historical earthquakes. Also included is seismological information for the historical earthquake.

Length This field specifies the end-to-end length of the Quaternary-age fault as measured from the most distal ends of the trace. The ends of overlapping or echelon traces are projected to a line defined by the average strike and the length is then determined from those projected end points. Also shown (in parentheses) is the cumulative length 
of all surface traces included in the fault, fault zone, or collection of faults. Lengths reported for lineaments are not necessarily meaningful, since little is known about the extent of Quaternary rupturing (if any) that has occurred along the structure.

Name (Fault name or Section name) The earliest referenced name for a fault or lineament (where appropriate) generally is given preference, except in cases where a more commonly accepted name is widely used in the recent literature. "Comments" also contains other names and references in which they are used, the geographic limits of the structure, north to south or west to east, as shown in this compilation; various geographic limits that are different in other studies are also included. Minor changes in original name may have been made for reasons of clarity or consistency where appropriate. We have found no faults in Brazil that justify using the term "fault segment or fault section", owing to a general lack of timing information.

\section{Number}

Structure number The structure (fault or lineament) is assigned a number that is preceded by a two character abbreviation (BR, Brazil; VE, Venezuela; etc.) that is unique to each of the countries in the Western Hemisphere. References to any structure that is also shown in other compilations are included in "Comments".

Section number An alpha character is assigned to the northernmost or westernmost section of a fault. Section nomenclature was not used for the Brazilan database.

Number of sections (only used for faults with sections; none in Brazil) Numeric value for number of sections (e.g., 4) defined in studies that do not meet the minimum requirements for segments established for this compilation. "Comments" include reference in which sections are discussed; if the term "segment" is used in the literature, an explanation of why "section" is used in the database is provided.

Recurrence interval Time interval in yr (based on historic data, calendric or calibrated radiocarbon dates), in ${ }^{14} \mathrm{C}$ $\mathrm{yr}$ (based on uncalibrated radiocarbon dates), or in k.y. (thousand years, based on less precise dating methods, stratigraphy, or geomorphology). Unknown is shown if there is no published recurrence interval value. Also included is the time interval (in parenthesis) for which this recurrence interval is valid (e.g., 10-130 k.y.).

Alternative published recurrence intervals, starting with that which applies to the most recent time interval, are included in "Comments."

References A bibliographic citation is included for all references pertinent to each structure. Each description of a fault or lineament is referenced separately, which is a requirement of the computer database. The term "Anais" is Portuguese for "Proceedings"; as such, these references are typically abstracts or short papers.

Section A geographic, geometric, or structural portion of a fault or collection of faults that appear(s) to have a different character than adjacent portions of the fault (or fold). Typically, not enough information exists to show that this portion of the fault acts independently of adjacent portions, and thus does not qualify as a bona fide "segment" of a fault in a paleoseismic sense. There are no known faults with proven segments or known sections in Brazil. Further research is needed to document additional faults with sections or those with sections that may in fact be segments.

Sense of movement Includes faults with thrust (less than $45^{\circ}$ dip); reverse, greater than $45^{\circ}$ dip; right lateral (dextral); left lateral (sinistral); or normal geometries. For oblique slip, principle sense of movement is followed by secondary sense (i.e., dextral, thrust). Ratios of the slip components are included, where known, in order to better characterize sense of movement.

Slip rate The primary field shows an actual value (i.e., $0.8 \mathrm{~mm} / \mathrm{yr}$ ) or one of several slip-rate categories used for the map part of this compilation. These categories are $<1 \mathrm{~mm} / \mathrm{yr}, 1-5 \mathrm{~mm} / \mathrm{yr}$, and $>5 \mathrm{~mm} / \mathrm{yr}$. "Unknown" precedes the suspected slip-rate or slip rate category if no published slip rate is known (e.g., Brazil). "Comments" may include a synopsis of published slip rates and pertinent documentation. Generally speaking, there are two types of slip rates. The first type is termed a "Geologic slip rate" and is derived from the age and amount of offset of surficial geologic deposits. These rates are not precise, but allow one to place broad limits on possible slip rates, and hence characterize the fault in one of the above-mentioned categories. The second type of slip rate is 
termed a "Paleoseismic slip rate" and is derived from times of faulting events and amounts of offset of geologic datums or piercing point. This type of slip rate is more precise, but are rare owing to the extensive amount of work involved (i.e., detailed paleoseismologic studies involving trenching and numeric dating).

Synopsis and geologic setting This field provides 1) a short summary that describes the level of study, 2) a snapshot of the scope of data that follows in the database and 3) a generalized perspective of the fault in terms of its regional geologic setting, amount of total offset, and general age of offset strata.

Timing of most recent event (faulting) The primary field shows one of two prehistoric time categories: latest Quaternary (Holocene and latest Pleistocene, $<15 \mathrm{ka}$ ) or Quaternary $(<1.6 \mathrm{Ma})$.

Type of studies This field briefly summarizes the types of studies conducted on the fault.

\section{ACKNOWLEDGEMENTS}

This project was supported by the USGS National Earthquake Hazards Reduction Program (NEHRP) and by the International Lithosphere Program (ILP) under Task Group II-2. Carlos Costa (Universidad de San Luis, Argentina) is the ILP II-2 Regional Coordinator for South America and, as such, provided logistical support and coordination for the project and its participants in South America. In addition, Dr. Costa translated some portions of the text from Spanish to English. ILP Task Groups II-2 and II-5 supported Allaoua Saadi's attendance at a Paleoseismology Training Session in Venezuela (March 1997), which provided a rare opportunity for direct exchanges between project participants in the USA and Brazil.

The senior author thanks the Federal University of Minas Gerais (UFMG), through the Institute of Geoscience and its Professor Manoel T. da Costa Research Center, for the use of computer facilities and time to prepare this report. He also thanks Fundação de Amparo à Pesquisa de Minas Gerais (FAPEMIG), Pró-Reitoria de Pesquisa da UFMG (PrPq/UFMG), and Conselho Nacional de Desenvolvimento Científico e Tecnológico (CNPq), for financial support to complete this project. Geologists Yociteru Hasui (UNESP), Joaquim Torquato (UFCe), Emanuel Jardim de Sá (UFRN), and João Batista Sena Costa (UFPA) are thanked for their invitations to visit several regions of Brasil and for their discussions about the geological and tectonic framework of Brazil. Professor Francisco Hilario R. Bezerra, Departamento de Geologia, CCET, Universidade Federal do Rio Grande do Norte (UFRN), graciously reviewed the data and map for ILP Task Group II-2. His assistance is greatly appreciated.

\section{REFERENCES}

Almeida, F.F.M. de, 1976, The system of continental rifts bordering the Santos Basin, Brazil: An. Acad. Bras. Cien., v. 48 (Supl.), p. 15-16.

Almeida, F.F.M. de., Hasui, Y., Brito Neves, B.B. de., and Fuck, R.A., 1981, Brazilian structural provinces-An introduction: Earth Science Review, v. 17, p. 1-29.

Brito Neves, B.B. de, 1991, Os dois "Brasís" geotectônicos, in Simpósio de Geologia do Nordeste, 15, Recife-PE, 1991: Anais. . . Recife-PE, SBG-NE, 1991, Boletim 12 da SBG-NE, p. 6-8.

Petri, S., and Fúlfaro, V.J., 1983, Geologia do Brasil—Fanerozóico: Editora da USP, São Paulo.

Saadi, A., 1993, Neotectônica da Plataforma Brasileira-E esboço e interpretação preliminares:Geonomos, Belo HorizonteMG, v.1, no. 1, p. 1-15.

Sampaio, A.V., and Northfleet, A., 1973, Estratigrafia e correlação das bacias sedimentares brasileiras: XXVII Cong. Bras. Geol., Aracajú-SE, v.3, p. 189-206.

Schobbenhaus C. (coord.), 1975, Carta geológica do Brasil ao Milionésimo, Folha Goiás (SD.22): Brasília-DF, MME/DGM/DNPM, $114 \mathrm{p}$.

Schobbenhaus, C., Campos, D.A., Derze, G.E., and Asmus, H.E. 1981, Mapa geológico do Brasil e da área oceânica adjacente incluindo depósitos minerais: Brasília-DF, MME/DGM/DNPM, escala 1:2.500.000. 


\section{DATABASE FOR BRAZIL}

\section{BR-01, PROPRIÁ FAULT ZONE (AND LINEAMENT)}

FAULT NUMBER: BR-01

Comments: Shown as fault ALA-01 on initial compilation.

FAULT NAME: Propriá (fault zone and linement)

SYNOPSIS AND GEOLOGIC SETTING: The Propriá fault zone affects the Precambrian igneous-metamorphic units that are deformed by Brasiliano Orogenesis (Neoproterozoic). In the north margin of the southern Northeast region, it forms the west side of Mesozoic sediment of the Sergipe-Alagoas and Recôncavo Basins. The fault and associated linement were apparently formed during the fragmentation of Gondwana. They correspond to a magnetic alignment that signals the probable existence of an older and deeper suture, termed the "Propriá Lineament."

COMPILER AFFILIATION, AND DATE OF COMPILATION: Allaoua Saadi (Univ. Federal de Minas Gerais, Belo Horizonte, Brasil), March 1997.

TYPE OF STUDIES: Compilation of cartographic and bibliographic data, as well as regional field data.

FAULT GEOMETRY

LENGTH : $575 \mathrm{~km}$ end to end ( $577 \mathrm{~km}$ cumulative)

END POINTS: $8^{\circ} 59^{\prime} 54^{\prime \prime} \mathrm{S}, 35^{\circ} 1^{\prime} 33^{\prime \prime} \mathrm{W} ; 12^{\circ} 27^{\prime} 24^{\prime \prime} \mathrm{S}, 38^{\circ} 49^{\prime} 54^{\prime \prime} \mathrm{W} . A V E R A G E$ STRIKE: $47^{\circ}$

AVERAGE DIP: Probably $70^{\circ} \mathrm{E}$.

SENSE OF MOVEMENT: Normal, down to southeast

Comments: Probably has a strike-slip component. Interpretation from analysis of general geological and geomorphological information.

GEOMORPHIC EXPRESSIONS: Forms scarps and affects local base level in small rivers. In the states of Sergipe and Alagoas, this fault (lineament) establishes the contact between the regions comprised of internal plateaus and the coastal tablelands. In the state of Bahia, the fault establishes the margin of the Mezosoic Tucano-Jatobá basins and the Recôncavo basin, where it has a very impressive scarp.

RECURRENCE INTERVAL: Unknown

SLIP RATE: Unknown, probably $<1 \mathrm{~mm} / \mathrm{yr}$.

TIME OF MOST RECENT OF MOVEMENT: Quaternary (<1.6 Ma)

Comments The timing is based on geomorphological evidence and on faults that affect Pliocene sediment of the Barreiras Group. It is probable that, at least in the state of Bahia, fault activity extends to the Holocene, as is suggested by evidence of subsidence in the Todos os Santos Bay.

\section{REFERENCES}

Martin, L., Flexor, J.M., Bittencourt, A.C. da S.P., and Dominguez, J.M.L., 1986, Neotectonic Movements on a Passive Continental Margin, Salvador Region, Brazil: Neotectonics-An International Journal of Crustal Dynamics, v. 1, p. 87-103.

Riccomini, C., and Assumpção, M., 1999, Quaternary tectonics in Brazil: Epidodes, v. 22, no. 3., p. 221-225

Saadi, A., 1993, Neotectônica da Plataforma Brasileira: Esboço e interpretação preliminares: Geonomos, Belo HorizonteMG, v. 1, no. 1, p. 1-15.

Saadi, A. 1994, A Descontinuidade Crustal Minas-Alagoas-Uma faixa rúptil ativa durante o Cenozóico, in Congresso Brasileiro de Geologia, 38, Balneário Camboriú-SC, 1994: Anais Sociedade Brasileira de Geologia, Balneário Camboriú-SC, v. 2, p. 256-257. 


\section{BR-02, AMAPÁ FAULT}

FAULT NUMBER: BR-02

Comments: Shown as fault AMP-01 on initial compilation.

FAULT NAME: Amapá

SYNOPSIS AND GEOLOGIC SETTING: The Amapá fault is located in the northeast margin of the Brazilian Territory, in the coastal region of the state of Amapá, (frontier state with French Guyana). It establishes the contact between Precambrian basement and Tertiary-Quaternary sedimentary cover of the coast (Barreiras Group, among others).

COMPILER AFFILIATION, AND DATE OF COMPILATION: Allaoua Saadi (Univ. Federal de Minas Gerais, Belo Horizonte, Brasil), March 1997.

TYPE OF STUDIES: Compilation of cartographic and bibliographic data.

\section{FAULT GEOMETRY}

LENGTH: $414 \mathrm{~km}$ end to end (416 km cumulative)

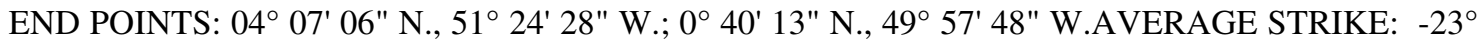

AVERAGE DIP: Subvertical, inclined to east

SENSE OF MOVEMENT: Normal, down to east

GEOMORPHIC EXPRESSION: Strong structural control of the coastline of Amapá and the Uacá River estuary to the north.

RECURRENCE INTERVAL: Unknown

SLIP RATE: Unknown, probably $<1 \mathrm{~mm} / \mathrm{yr}$.

TIME OF MOST RECENT OF MOVEMENT: Quaternary (<1.6 Ma)

Comments: Timing based on subsidence of Quaternary sedimentary cover whose extension, to west, is controlled by the fault.

\section{REFERENCES}

Assumpção, M., Suarez, G., and Veloso, J.A., 1985, Fault plane solutions of intraplate earthquakes in Brazil—Some constraints on the regional stress field: Tectonophysics, v. 113, p. 283-293.

Corrêa, A.C., e Costa, L.T. da R., 1994, A aplicação de imagens de radar na análise morfotectônica da parte oriental do Estado do amapá, Brasil, in Congresso Brasileiro de Geologia, 38, Balneário Camboriu, 1994: Anais Sociedade Brasileira de Geologia, Balneário Camboriú-SC, v. 1, p. 446-447.

Lima, M.I.C., Bezerra, P.E.L., e Araújo, H.J.T., 1991, Sistematização da geologia do Estado do Amapá, in Simpãsio de Geologia da Amazonia, 3, Belém, 1991: Anais Sociedade Brasileira de Geologia/Núcleo Norte, Belém-PA, p. 322335 .

\section{BR-03, EURINEPÉ LINEAMENT}

FAULT NUMBER: BR-03

Comments: Shown as fault AMZ-01 on initial compilation.

FAULT NAME: Eurinepé (lineament)

SYNOPSIS AND GEOLOGIC SETTING: The Eurinepé lineament is located in the west margin of Brazilian Amazônia, state of Amazonas. The Brazilian Amazônia is in the axis of the Intracontinental Amazonas Basin (Paleozoic-Mesozoic), which has a thick cover of Cenozoic sediment. 
COMPILER AFFILIATION, AND DATE OF COMPILATION: Allaoua Saadi (Univ. Federal de Minas Gerais, Belo Horizonte, Brasil), March 1997.

TYPE OF STUDIES: Compilation of cartographic and bibliographic data.

\section{FAULT GEOMETRY}

LENGTH: $472 \mathrm{~km}$ end to end (472 km cumulative)

END POINTS: $5^{\circ} 57^{\prime} 14^{\prime \prime}$ S., $67^{\circ} 47^{\prime} 13^{\prime \prime} \mathrm{W} . ; 6^{\circ} 27^{\prime} 9^{\prime \prime}$ S., $72^{\circ} 0^{\prime} 9^{\prime \prime} \mathrm{W}$.

AVERAGE STRIKE: $83^{\circ}$

AVERAGE DIP: Unknown

SENSE OF MOVEMENT: Probably strike-slip with reverse component

Comments: Strike slip (lateral sense unknown) and reverse component (west side up?) is based on data of Cunha (1988).

GEOMORPHIC EXPRESSION: Strong (structural) control of the valley of Upper Juruá River and of the edge of its flood plain.

\section{RECURRENCE INTERVAL: Unknown}

SLIP RATE: Unknown, probably $<1 \mathrm{~mm} / \mathrm{yr}$.

TIME OF MOST RECENT OF MOVEMENT: Quaternary (<1.6 Ma)

Comments: It may have been active in the Holocene, and perhaps quite recently (based on geomorphological analysis). However, there is no conclusive data to prove this young activity.

\section{REFERENCES}

Assumpção, M., Suarez, G., and Veloso, J.A., 1985, Fault plane solutions of intraplate earthquakes in Brazil-Some constraints on the regional stress field: Tectonophysics, v. 113, p. 283-293.

Bemerguy, R.L., e Sena Costa, J.B., 1991, Considerações sobre a evolução do sistema de drenagem da Amazônia e sua relação com o arcabouço tectônico-estrutural: Boletim do Museu Paraense Emílio Goeldi, Série Ciências da Terra, v. 3, p. 76-97.

Cunha, F.M.B. da, 1988, Controle tectônico-estrutural na hidrografia na região do Alto Amazonas, in Congresso Brasileiro de Geologia, 35, Bélem, 1988: Anais Sociedade Brasileira de Geologia, Belém-NO, v. 5, p. 2267-2273.

Cunha, F.M.B. da, 1991, Morfologia e neotectonismo do Rio Amazonas, in Simpósio de Geologia da Amazônia, 3, Belém, 1991: Anais Sociedade Brasileira de Geologia/Núcleo Norte, Belém-PA, p. 193-210.

Iriondo, M.H., and Suguio, K., 1981, Neotectonics of the Amazon Plain: Bulletin of INQUA, Neotectonic Commission, v. 4, p. $72-78$.

Lima, M.C., 1988, Lineamentos estruturais na seqüência cenozóica Solimões e suas relações com o Cráton Amazônico e Bacia do Alto Amazonas, in Congresso Brasileiro de Geologia, 35, Bélem, 1988: Anais Sociedade Brasileira de Geologia, Belém-NO, v. 6, p. 2396-2402.

Sternberg, H.O., 1950, Vales tectônicos na planície amazônica: Revista Brasileira de Geografia, Rio de Janeiro, v. 12, no. 4, p. 3-26.

Sternberg, H.O., 1953, Sismicidade e morfologia na Amazônia Brasileira: Anais da Academia Brasileira de Ciências, v. 25, no. 4 , p. $443-453$.

\section{BR-04, LOWER JURUÁ FAULT ZONE}

FAULT NUMBER: BR-04

Comments: Shown as fault AMA-02 on initial compilation.

FAULT NAME: Lower Juruá (fault zone) 
SYNOPSIS AND GEOLOGIC SETTING: The Lower Juruá fault zone is located in the western part of the state of Amazonas, along the lower valley of the Juruá River. It is in the western Intracratonic Amazonas Basin (Paleozoic-Mesozoic), which has a thick cover of Cenozoic sediment.

COMPILER AFFILIATION, AND DATE OF COMPILATION: Allaoua Saadi (Univ. Federal de Minas Gerais, Belo Horizonte, Brasil), March 1997.

TYPE OF STUDIES: Compilation of cartographic and bibliographic data.

FAULT GEOMETRY

LENGTH: $491 \mathrm{~km}$ end to end (494 km cumulative)

END POINTS: $2^{\circ} 14^{\prime} 21^{\prime \prime}$ S., $65^{\circ} 2^{\prime} 39^{\prime \prime} \mathrm{W} . ; 5^{\circ} 51^{\prime} 5^{\prime \prime} \mathrm{S}$., $67^{\circ} 35^{\prime} 56^{\prime \prime} \mathrm{W}$.

AVERAGE STRIKE: $035^{\circ}$

Comments: The data is related to the main axis of the fault zone.

AVERAGE DIP: Unknown angle to the northwest?

SENSE OF MOVEMENT: Reverse, probably with strike-slip component.

Comments: Reverse component is northwest side up; lateral sense unknown. Sense of movement is based on data of Cunha (1988 and 1991).

GEOMORPHIC EXPRESSION: Strong (structural) control of the lower valley of Juruá River, after inflection of $45^{\circ}$.

RECURRENCE INTERVAL: Unknown

SLIP RATE: Unknown, probably $<1 \mathrm{~mm} / \mathrm{yr}$.

TIME OF MOST RECENT OF MOVEMENT: Quaternary (<1.6 Ma)

\section{REFERENCES}

Assumpção, M., Suarez, G., and Veloso, J.A., 1985, Fault plane solutions of intraplate earthquakes in Brazil-Some constraints on the regional stress field: Tectonophysics, v. 113, p. 283-293.

Bemerguy, R.L., e Sena Costa, J.B., 1991, Considerações sobre a evolução do sistema de drenagem da Amazônia e sua relação com o arcabouço tectônico-estrutural: Boletim do Museu Paraense Emílio Goeldi, Série Ciências da Terra, v. 3, p. 76-97.

Cunha, F.M.B. da, 1988, Controle tectônico-estrutural na hidrografia na região do Alto Amazonas, in Congresso Brasileiro de Geologia, 35, Bélem, 1988: Anais Sociedade Brasileira de Geologia, Belém-NO, v. 5, p. 2267-2273.

Cunha, F.M.B. da, 1991, Morfologia e neotectonismo do Rio Amazonas, in Simpósio de Geologia da Amazônia, 3, Belém, 1991: Anais Sociedade Brasileira de Geologia/Núcleo Norte, Belém-PA, p. 193-210.

Iriondo, M.H., and Suguio, K., 1981, Neotectonics of the Amazon Plain: Bulletin of INQUA, Neotectonic Commission, v. 4, p. $72-78$.

Lima, M.C., 1988, Lineamentos estruturais na seqüência cenozóica Solimões e suas relações com o Cráton Amazônico e Bacia do Alto Amazonas, in Congresso Brasileiro de Geologia, 35, Bélem, 1988: Anais Sociedade Brasileira de Geologia, Belém-NO, v. 6, p. 2396-2402.

Sternberg, H.O., 1950, Vales tectônicos na planície amazônica: Revista Brasileira de Geografia, Rio de Janeiro, v. 12, no. 4, p. 3-26.

Sternberg, H.O., 1953, Sismicidade e morfologia na Amazônia Brasileira: Anais da Academia Brasileira de Ciências, v. 25, no. 4 , p. 443-453.

\section{BR-05, CODAJÁS FAULT}

FAULT NUMBER BR-05

Comments: Shown as fault AMZ-03 on initial compilation.

FAULT NAME: Codajás 
SYNOPSIS AND GEOLOGIC SETTING: The Codajás fault is located in the central part of the Amazônica Plain, state of Amazonas. It is in the axis of the Intracratonic Amazonas Basin (Paleozoic-Mesozoic), which has a thick cove of Cenozoic sediment.

COMPILER AFFILIATION, AND DATE OF COMPILATION: Allaoua Saadi (Univ. Federal de Minas Gerais, Belo Horizonte, Brasil), March 1997.

TYPE OF STUDIES: Compilation of cartographic and bibliographic data.

\section{FAULT GEOMETRY}

LENGTH: $155 \mathrm{~km}$ end to end (155 km cumulative)

END POINTS: $3^{\circ} 11^{\prime} 36^{\prime \prime}$ S., $62^{\circ} 25^{\prime} 2^{\prime \prime} \mathrm{W}$.; $3^{\circ} 56^{\prime} 55^{\prime \prime}$ S., $61^{\circ} 14^{\prime} 27^{\prime \prime} \mathrm{W}$.

AVERAGE STRIKE: $-57^{\circ}$

AVERAGE DIP: Unknown angle to the southwest?

SENSE OF MOVEMENT: Reverse with strike-slip component

Comments: Reverse sense is southwest side up, with unknown sense of lateral (strike-slip) component Sense of movement is based on data of Cunha (1988) and Assumpção and Suarez (1988).

GEOMORPHIC EXPRESSION: Strong structural control of the gutter (main channel) and flood plain of the Amazonas River, in the Codajás region.

RECURRENCE INTERVAL: Unknown

SLIP RATE: Unknown, probably $<1 \mathrm{~mm} / \mathrm{yr}$.

TIME OF MOST RECENT OF MOVEMENT: Holocene and post glacial ( $<15 \mathrm{ka})$

Comments: Fault is seemingly young $(<15 \mathrm{ka})$ as suggested by structural control of river geomorphology. Also, Assumpção and Suarez (1988) reported that the fault is active from a seismic point of view.

\section{REFERENCES}

Assumpção, M., Suarez, G., and Veloso, J.A., 1985, Fault plane solutions of intraplate earthquakes in Brazil—Some constraints on the regional stress field: Tectonophysics, v. 113, p. 283-293.

Assumpção, M., and Suarez, G., 1988, Source mechanism of moderate size earthquakes and stress orientation in mid-plate South America: Geophysical Journal, v. 92, p. 253-267.

Cunha, F.M.B. da, 1988, Controle tectônico-estrutural na hidrografia na região do Alto Amazonas, in Congresso Brasileiro de Geologia, 35, Bélem, 1988: Anais Sociedade Brasileira de Geologia, Belém-NO, v. 5, p. 2267-2273.

Cunha, F.M.B. da, 1991, Morfologia e neotectonismo do Rio Amazonas, in Simpósio de Geologia da Amazônia, 3, Belém, 1991: Anais Sociedade Brasileira de Geologia/Núcleo Norte, Belém-PA, p. 193-210.

Iriondo, M.H., and Suguio, K., 1981, Neotectonics of the Amazon Plain: Bulletin of INQUA, Neotectonic Commission, v. 4, p. $72-78$.

Sternberg, H.O., 1950, Vales tectônicos na planície amazônica: Revista Brasileira de Geografia, Rio de Janeiro, v. 12, no. 4, p. 3-26.

Sternberg, H.O., 1953, Sismicidade e morfologia na Amazônia Brasileira: Anais da Academia Brasileira de Ciências, v. 25, no. 4, p. 443-453.

\section{BR-06, RIO JUTAÍ FAULT ZONE}

FAULT NUMBER: BR-06

Comments: Shown as fault AMZ-04 on initial compilation.

FAULT NAME: Rio Jutaí (fault zone)

SYNOPSIS AND GEOLOGIC SETTING: The Jutaí River fault zone is located in the west margin of the Solimões River (Upper Amazonas), in the western part of the state of Amazonas, along the valley of the Jutaí River. It is 
in the axis of the Intracratonic Amazonas Basin (Paleozoic-Mesozoic), which has a thick cover of Cenozoic sediment.

COMPILER AFFILIATION, AND DATE OF COMPILATION: Allaoua Saadi (Univ. Federal de Minas Gerais, Belo Horizonte, Brasil), March 1997.

TYPE OF STUDIES: Compilation of cartographic and bibliographic data.

FAULT GEOMETRY

LENGTH: $500 \mathrm{~km}$ end to end (502 km cumulative)

END POINTS: $2^{\circ} 15^{\prime} 6^{\prime \prime} \mathrm{S} ., 66^{\circ} 25^{\prime} 52^{\prime \prime} \mathrm{W}$.; $5^{\circ} 48^{\prime} 56^{\prime \prime}$ S., $69^{\circ} 10^{\prime} 48^{\prime \prime} \mathrm{W}$.

AVERAGE STRIKE: $38^{\circ}$

Comments: The data is related to the main axis of the fault zone, which is relatively sinuous.

AVERAGE DIP: Unknown angle to the northwest?

SENSE OF MOVEMENT: Reverse with strike-slip component.

Comments: Reverse component is northwest side up, unknown lateral sense of strike slip.

GEOMORPHIC EXPRESSION: Strong structural control of the valley of the Jutaí River.

RECURRENCE INTERVAL: Unknown

SLIP RATE: Unknown, probably $<1 \mathrm{~mm} / \mathrm{yr}$.

TIME OF MOST RECENT OF MOVEMENT: Quaternary $(<1.6 \mathrm{Ma})$

\section{REFERENCES}

Assumpção, M., Suarez, G., and Veloso, J.A., 1985, Fault plane solutions of intraplate earthquakes in Brazil—Some constraints on the regional stress field: Tectonophysics, v. 113, p. 283-293.

Assumpção, M., and Suarez, G., 1988, Source mechanism of moderate size earthquakes and stress orientation in mid-plate South America: Geophysical Journal, v. 92, p. 253-267.

Bemerguy, R.L., e Sena Costa, J.B., 1991, Considerações sobre a evolução do sistema de drenagem da Amazônia e sua relação com o arcabouço tectônico-estrutural: Boletim do Museu Paraense Emílio Goeldi, Série Ciências da Terra, v. 3, p. 76-97.

Cunha, F.M.B. da, 1988, Controle tectônico-estrutural na hidrografia na região do Alto Amazonas, in Congresso Brasileiro de Geologia, 35, Bélem, 1988: Anais Sociedade Brasileira de Geologia, Belém-NO, v. 5, p. 2267-2273.

Cunha, F.M.B. da, 1991, Morfologia e neotectonismo do Rio Amazonas, in Simpósio de Geologia da Amazônia, 3, Belém, 1991: Anais Sociedade Brasileira de Geologia/Núcleo Norte, Belém-PA, p. 193-210.

Iriondo, M.H., and Suguio, K., 1981, Neotectonics of the Amazon Plain: Bulletin of INQUA, Neotectonic Commission, v. 4, p. $72-78$.

Lima, M.C., 1988, Lineamentos estruturais na seqüência cenozóica Solimões e suas relações com o Cráton Amazônico e Bacia do Alto Amazonas, in Congresso Brasileiro de Geologia, 35, Bélem, 1988: Anais Sociedade Brasileira de Geologia, Belém-NO, v. 6, p. 2396-2402.

Sternberg, H.O., 1950, Vales tectônicos na planície amazônica: Revista Brasileira de Geografia, Rio de Janeiro, v. 12, no. 4, p. 3-26.

Sternberg, H.O., 1953, Sismicidade e morfologia na Amazônia Brasileira: Anais da Academia Brasileira de Ciências, v. 25, no. 4 , p. 443-453.

\section{BR-07, LOWER COARÍ FAULT ZONE}

\section{FAULT NUMBER: BR-07}

Comments: Shown as fault AMZ-05 on initial compilation.

FAULT NAME: Lower Coarí (fault zone) 
SYNOPSIS AND GEOLOGIC SETTING: The Lower Coarí fault zone is located in the west margin of the Solimões River (Upper Amazonas), in the western part of the state of Amazonas, along the valley of the Coarí River. It is in the axis of the Intracratonic Amazonas Basin (Paleozoic-Mesozoic), which has a thick cover of Cenozoic sediment.

COMPILER, AFFILIATION, AND DATE OF COMPILATION: Allaoua Saadi (Univ. Federal de Minas Gerais, Belo Horizonte, Brasil), March 1997.

TYPE OF STUDIES: Compilation of cartographic and bibliographic data.

FAULT GEOMETRY

LENGTH: $230 \mathrm{~km}$ end to end ( $233 \mathrm{~km}$ cumulative)

END POINTS: $4^{\circ} 12^{\prime} 31^{\prime \prime}$ S., $63^{\circ} 3^{\prime} 26^{\prime \prime} \mathrm{W}$.; 5 $38^{\prime} 59^{\prime \prime}$ S., 64 $32^{\prime} 52^{\prime \prime} \mathrm{W}$.

AVERAGE STRIKE: $46^{\circ}$

Comments: The data is related to the main axis of the fault zone, which is relatively sinuous.

AVERAGE DIP: Unknown angle to the northwest?

SENSE OF MOVEMENT: Reverse with probable strike-slip component

Comments: Reverse component is northwest side up, unknown lateral sense of strike slip.

GEOMORPHIC EXPRESSION: Strong structural control of the lower valley of the Coarí River and the southeast border of Coarí Lake.

RECURRENCE INTERVAL: Unknown

SLIP RATE: Unknown, probably $<1 \mathrm{~mm} / \mathrm{yr}$.

TIME OF MOST RECENT OF MOVEMENT: Quaternary (<1.6 Ma)

\section{REFERENCES}

Assumpção, M., Suarez, G., and Veloso, J.A., 1985, Fault plane solutions of intraplate earthquakes in Brazil—Some constraints on the regional stress field: Tectonophysics, v. 113, p. 283-293.

Assumpção, M., and Suarez, G., 1988, Source mechanism of moderate size earthquakes and stress orientation in mid-plate South America: Geophysical Journal, v. 92, p. 253-267.

Bemerguy, R.L., e Sena Costa, J.B., 1991, Considerações sobre a evolução do sistema de drenagem da Amazônia e sua relação com o arcabouço tectônico-estrutural: Boletim do Museu Paraense Emílio Goeldi, Série Ciências da Terra, v. 3, p. 76-97.

Cunha, F.M.B. da, 1988, Controle tectônico-estrutural na hidrografia na região do Alto Amazonas, in Congresso Brasileiro de Geologia, 35, Bélem, 1988: Anais Sociedade Brasileira de Geologia, Belém-NO, v. 5, p. 2267-2273.

Cunha, F.M.B. da, 1991, Morfologia e neotectonismo do Rio Amazonas, in Simpósio de Geologia da Amazônia, 3, Belém, 1991: Anais Sociedade Brasileira de Geologia/Núcleo Norte, Belém-PA, p. 193-210.

Iriondo, M.H., and Suguio, K., 1981, Neotectonics of the Amazon Plain: Bulletin of INQUA, Neotectonic Commission, v. 4, p. $72-78$.

Lima, M.C., 1988, Lineamentos estruturais na seqüência cenozóica Solimões e suas relações com o Cráton Amazônico e Bacia do Alto Amazonas, in Congresso Brasileiro de Geologia, 35, Bélem, 1988: Anais Sociedade Brasileira de Geologia, Belém-NO, v. 6, p. 2396-2402.

Sternberg, H.O., 1950, Vales tectônicos na planície amazônica: Revista Brasileira de Geografia, Rio de Janeiro, v. 12 , no. 4, p. 3-26.

Sternberg, H.O., 1953, Sismicidade e morfologia na Amazônia Brasileira: Anais da Academia Brasileira de Ciências, v. 25, no. 4 , p. $443-453$. 


\section{BR-08, LOWER PURÚS FAULT ZONE}

FAULT NUMBER: BR-08

Comments: Shown as fault AMZ-06 on initial compilation.

FAULT NAME: Lower Purús (fault zone)

SYNOPSIS AND GEOLOGIC SETTING: The Lower Purús fault zone is located in the west margin of the Solimões River (upper Amazonas), in the western part of the state of Amazonas, along the lower valley of the Purús River. It is in the axis of the Intracratonic Amazonas Basin (Paleozoic-Mesozoic), which has a thick cover of Cenozoic sediment.

COMPILER AFFILIATION, AND DATE OF COMPILATION: Allaoua Saadi (Univ. Federal de Minas Gerais, Belo Horizonte, Brasil) March 1997.

TYPE OF STUDIES: Compilation of cartographic and bibliographic data.

FAULT GEOMETRY

LENGTH: $312 \mathrm{~km}$ end to end ( $312 \mathrm{~km}$ cumulative)

END POINTS: $3^{\circ} 46^{\prime} 13^{\prime \prime}$ S., $60^{\circ} 59^{\prime} 28^{\prime \prime} \mathrm{W}$.; $5^{\circ} 41^{\prime} 36^{\prime \prime} \mathrm{S} ., 63^{\circ} 2^{\prime} 7^{\prime \prime} \mathrm{W}$.

AVERAGE STRIKE: $47^{\circ}$

Comments: The data is related to the main axis of the fault zone, which is relatively sinuous.

AVERAGE DIP: Unknown angle to the northwest?

SENSE OF MOVEMENT: Reverse probably with strike-slip component

Comments: Reverse component is northwest side up, unknown lateral sense of strike slip.

GEOMORPHIC EXPRESSION: Strong (structural) control of the lower valley of the Purús River, as noted by a change in stream pattern (meanders).

RECURRENCE INTERVAL: Unknown

SLIP RATE: Unknown, probably $<1 \mathrm{~mm} / \mathrm{yr}$.

TIME OF MOST RECENT OF MOVEMENT: Quaternary $(<1.6 \mathrm{Ma})$

\section{REFERENCES}

Assumpção, M., Suarez, G., and Veloso, J.A., 1985, Fault plane solutions of intraplate earthquakes in Brazil—Some constraints on the regional stress field: Tectonophysics, v. 113, p. 283-293.

Assumpção, M., and Suarez, G., 1988, Source mechanism of moderate size earthquakes and stress orientation in mid-plate South America: Geophysical Journal, v. 92, p. 253-267.

Bemerguy, R.L., e Sena Costa, J.B., 1991, Considerações sobre a evolução do sistema de drenagem da Amazônia e sua relação com o arcabouço tectônico-estrutural: Boletim do Museu Paraense Emílio Goeldi, Série Ciências da Terra, v. 3, p. 76-97.

Cunha, F.M.B. da, 1988, Controle tectônico-estrutural na hidrografia na região do Alto Amazonas, in Congresso Brasileiro de Geologia, 35, Bélem, 1988: Anais Sociedade Brasileira de Geologia, Belém-NO, v. 5, p. 2267-2273.

Cunha, F.M.B. da, 1991, Morfologia e neotectonismo do Rio Amazonas, in Simpósio de Geologia da Amazônia, 3, Belém, 1991: Anais Sociedade Brasileira de Geologia/Núcleo Norte, Belém-PA, p. 193-210.

Iriondo, M.H., and Suguio, K., 1981, Neotectonics of the Amazon Plain: Bulletin of INQUA, Neotectonic Commission, v. 4, p. $72-78$.

Lima, M.C., 1988, Lineamentos estruturais na seqüência cenozóica Solimões e suas relações com o Cráton Amazônico e Bacia do Alto Amazonas, in Congresso Brasileiro de Geologia, 35, Bélem, 1988: Anais Sociedade Brasileira de Geologia, Belém-NO, v. 6, p. 2396-2402. 
Sternberg, H.O., 1950, Vales tectônicos na planície amazônica: Revista Brasileira de Geografia, Rio de Janeiro, v. 12, no. 4, p. 3-26.

Sternberg, H.O., 1953, Sismicidade e morfologia na Amazônia Brasileira: Anais da Academia Brasileira de Ciências, v. 25, no. 4 , p. 443-453.

\section{BR-09, RIO MADEIRA FAULT ZONE}

FAULT NUMBER: BR-09

Comments: Shown as fault AMZ-07 on initial compilation.

FAULT NAME: Rio Madeira (fault zone)

SYNOPSIS AND GEOLOGIC SETTING: The Madeira River fault zone is located south of the Amazonas River, in the eastern part of the state of Amazonas, along the west margin of the valley of the Madeira River, downstream to its confluence with the Amazonas River. It is in the axis of the Intracratonic Amazonas Basin (PaleozoicMesozoic), which has a thick cover of Cenozoic sediment.

COMPILER AFFILIATION, AND DATE OF COMPILATION: Allaoua Saadi (Univ. Federal de Minas Gerais, Belo Horizonte, Brasil), March 1997.

TYPE OF STUDIES: Compilation of cartographic and bibliographic data.

\section{FAULT GEOMETRY}

LENGTH: $855 \mathrm{~km}$ end to end ( $856 \mathrm{~km}$ cumulative)

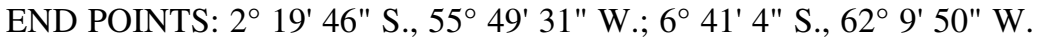

AVERAGE STRIKE: $56^{\circ}$

Comments: The data is related to the main axis of the fault zone, which is relatively sinuous.

AVERAGE DIP: Probably subvertical

SENSE OF MOVEMENT: Probably right lateral (dextral) strike-slip.

GEOMORPHIC EXPRESSION: Strong structural control of the valley of the Madeira River and of the portion of the Amazonas River between Itacoatiara and Itapiranga.

RECURRENCE INTERVAL: Unknown

SLIP RATE: Unknown

TIME OF MOST RECENT OF MOVEMENT: Quaternary $(<1.6 \mathrm{Ma})$

\section{REFERENCES}

Assumpção, M., Suarez, G., and Veloso, J.A., 1985, Fault plane solutions of intraplate earthquakes in Brazil—Some constraints on the regional stress field: Tectonophysics, v. 113, p. 283-293.

Assumpção, M., and Suarez, G., 1988, Source mechanism of moderate size earthquakes and stress orientation in mid-plate South America: Geophysical Journal, v. 92, p. 253-267.

Bemerguy, R.L., e Sena Costa, J.B., 1991, Considerações sobre a evolução do sistema de drenagem da Amazônia e sua relação com o arcabouço tectônico-estrutural: Boletim do Museu Paraense Emílio Goeldi, Série Ciências da Terra, v. 3, p. 76-97.

Costa, J.B.S., Hasui, H., Borges, M. da S., Bemerguy, R.L., Saadi, A., e Costa Jr, R.S., 1994, Arcabouço tectônico MesoCenozóico da região da calha do Amazonas, in Simpósio de Geologia da Amazônia, 4, Belém, 1994:, Anais Sociedade Brasileira de Geologia, Belém-NO, v. 1, p. 47-50.

Cunha, F.M.B. da, 1988, Controle tectônico-estrutural na hidrografia na região do Alto Amazonas, in Congresso Brasileiro de Geologia, 35, Bélem, 1988: Anais Sociedade Brasileira de Geologia, Belém-NO, v. 5, p. 2267-2273.

Cunha, F.M.B. da, 1991, Morfologia e neotectonismo do Rio Amazonas, in Simpósio de Geologia da Amazônia, 3, Belém, 1991: Anais Sociedade Brasileira de Geologia/Núcleo Norte, Belém-PA, p. 193-210. 
Iriondo, M.H., and Suguio, K., 1981, Neotectonics of the Amazon Plain: Bulletin of INQUA, Neotectonic Commission, v. 4, p. $72-78$.

Sternberg, H.O., 1950, Vales tectônicos na planície amazônica: Revista Brasileira de Geografia, Rio de Janeiro, v. 12 , no. 4, p. 3-26.

Sternberg, H.O., 1953, Sismicidade e morfologia na Amazônia Brasileira: Anais da Academia Brasileira de Ciências, v. 25, no. 4 , p. 443-453.

\section{BR-10, RIO NEGRO “A” FAULT}

FAULT NUMBER: BR-10

Comments: Shown as fault AMZ-08 on initial compilation.

FAULT NAME: Rio Negro "A"

SYNOPSIS AND GEOLOGIC SETTING: The Negro River "A" fault is located in the north margin of the Solimões-Amazonas axis, in the central eastern part of the state of Amazonas, along the lower valley of the Negro River, downstream to its confluence with the Solimões River. It is on the north side of the Intracratonic Amazonas Basin (Paleozoic-Mesozoic), which has a thick cover of Cenozoic sediment. The Negro River A fault forms the contact with Precambrian basement of the Guyanas Craton, to the north.

COMPILER AFFILIATION, AND DATE OF COMPILATION: Allaoua Saadi (Univ. Federal de Minas Gerais, Belo Horizonte, Brasil), March 1997.

TYPE OF STUDIES: Compilation of cartographic, bibliographic, and field data.

FAULT GEOMETRY

LENGTH: $267 \mathrm{~km}$ end to end (265 km cumulative)

END POINTS: $1^{\circ} 30^{\prime} 8^{\prime \prime}$ S., $61^{\circ} 35^{\prime} 38^{\prime \prime} \mathrm{W}$.; $3^{\circ} 25^{\prime} 51^{\prime \prime}$ S., $60^{\circ} 9^{\prime} 24^{\prime \prime} \mathrm{W}$.

AVERAGE STRIKE: $-37^{\circ}$

Comments: The data is related to the central axis of a fault zone that controlled the formation of the Lower Negro River Graben (based on Igreja and Franzinelli 1990).

AVERAGE DIP: Subvertical, to the northeast or southwest

SENSE OF MOVEMENT: Normal, down to southwest

GEOMORPHIC EXPRESSION: Fault forms low scarps and exerts strong structural control of the enlarged valley (graben) of the Lower Negro River.

\section{RECURRENCE INTERVAL: Unknown}

SLIP RATE: Unknown, probably $<1 \mathrm{~mm} / \mathrm{yr}$.

TIME OF MOST RECENT OF MOVEMENT: Quaternary (<1.6 Ma)

Comments: The geomorphological observations (pattern of fluvial dissection and detailed morphology of the Manaus region) suggest that fault activity could have continued into the Holocene, whereas seismicity (Assumpção Suarez 1988) suggests it is still active. However, no conclusive data exist to define young movement.

\section{REFERENCES}

Assumpção, M., Suarez, G., and Veloso, J.A., 1985, Fault plane solutions of intraplate earthquakes in Brazil—Some constraints on the regional stress field: Tectonophysics, v. 113, p. 283-293.

Assumpção, M., and Suarez, G., 1988, Source mechanism of moderate size earthquakes and stress orientation in mid-plate South America: Geophysical Journal, v. 92, p. 253-267.

Bemerguy, R.L., e Sena Costa, J.B., 1991, Considerações sobre a evolução do sistema de drenagem da Amazônia e sua relação com o arcabouço tectônico-estrutural: Boletim do Museu Paraense Emílio Goeldi, Série Ciências da Terra, v. 3, p. 76-97. 
Costa, J.B.S., Hasui, H., Borges, M. da S., Bemerguy, R.L., Saadi, A., e Costa Jr, R.S., 1994, Arcabouço tectônico MesoCenozóico da região da calha do Amazonas, in Simpósio de Geologia da Amazônia, 4, Belém, 1994: Anais Sociedade Brasileira de Geologia, Belém-NO, v. 1, p. 47-50.

Cunha, F.M.B. da, 1988, Controle tectônico-estrutural na hidrografia na região do Alto Amazonas, in Congresso Brasileiro de Geologia, 35, Bélem, 1988: Anais Sociedade Brasileira de Geologia, Belém-NO, v. 5, p. 2267-2273.

Cunha, F.M.B. da, 1991, Morfologia e neotectonismo do Rio Amazonas, in Simpósio de Geologia da Amazônia, 3, Belém, 1991: Anais Sociedade Brasileira de Geologia/Núcleo Norte, Belém-PA, p. 193-210.

Fernandes Filho, L.A., Costa, J.B.S., e Costa, M.L., 1995, Bacia de Manaus-Uma estrutura pull-apart do Quaternário, in Simpósio Nacional de Estudos Tectónicos, 5, Gramado-RS, 1995: Anais Sociedade Brasileira de Geologia, Porto Alegre-RS-CPGQ/UFRGS, p. 419-420.

Franzinelli, E., e Piuci, J., 1988, Evidências de neotectonismo na Bacia Amazônica, in Congresso Latino-Americano de

Geologia, 7, Belém, 1988: Anais Sociedade Brasileira de Geologia/Núcleo Norte, Belém-PA, p. 80-90.

Franzinelli, E., and Latrubesse, E., 1993, Neotectonics in the central part of the Amazon Basin: Bulletin of INQUA, Neotectonic Commission, v. 16, p. 10-13.

Igreja, H.L.S., e Franzinelli, E., 1987, Neotectônica; o lineamento Rio Negro, um exemplo: ICE Manaus, v. 4, p. 17-18.

Igreja, H.L.S., e Franzinelli, E., 1990, Estudos neotectônicos na região do Baixo Rio Negro - Centro-Nordeste do Estado do Amazonas, in Congresso Brasileiro de Geologia, 36, Natal, 1990: Anais Sociedade Brasileira de Geologia, Natal-RN, v,. 5, p. 2099-2109.

Iriondo, M.H., and Suguio, K., 1981, Neotectonics of the Amazon Plain: Bulletin of INQUA, Neotectonic Commission, v. 4, p. $72-78$.

Silva, C.L. da, Carvalho, J. da S., Alecrim, J.D., e Costa, S. Dos S., 1994, Considerações sobre neotectonismo na cidade de Manaus (AM) e áreas adjacentes, uma discussão preliminar, in Congresso Brasileiro de Geologia, 38, Balneário Camboriu, 1994: Anais Sociedade Brasileira de Geologia, Balneário Camboriu-SC, v. 2, p. 251-252.

Sternberg, H.O., 1950, Vales tectônicos na planície amazônica: Revista Brasileira de Geografia, Rio de Janeiro, v. 12 , no. 4, p. 3-26.

Sternberg, H.O., 1953, Sismicidade e morfologia na Amazônia Brasileira: Anais da Academia Brasileira de Ciências, v. 25, no. 4 , p. $443-453$.

\section{BR-11, BARCELOS FAULT}

FAULT NUMBER: BR-11

Comments: Shown as fault AMZ-09 on initial compilation.

FAULT NAME: Barcelos

SYNOPSIS AND GEOLOGIC SETTING: The Barcelos fault zone is located in the north margin of the SolimõesAmazonas axis, in the central eastern part of the state of Amazonas, along the lower valley of the Negro River, upstream of its confluence with the Branco River. It is on the north margin of the Intracratonic Amazonas Basin (Paleozoic-Mesozoic), within Precambrian basement of the Guyanas Craton.

COMPILER AFFILIATION, AND DATE OF COMPILATION: Allaoua Saadi (Univ. Federal de Minas Gerais, Belo Horizonte, Brasil), March 1997.

TYPE OF STUDIES: Compilation of cartographic and bibliographic data.

\section{FAULT GEOMETRY}

LENGTH: $226 \mathrm{~km}$ end to end (226 km cumulative)

END POINTS: $0^{\circ} 19^{\prime} 50^{\prime \prime}$ S., $63^{\circ} 35^{\prime} 32^{\prime \prime}$ W.; $1^{\circ} 19^{\prime} 57^{\prime \prime}$ S., 61 49' $16^{\prime \prime} \mathrm{W}$.

AVERAGE STRIKE: $-61^{\circ}$

Comments: The data is related to the central axis of a fault zone that controls the south border of the depression and confluence of Branco River-Negro River (based on Igreja and Franzinelli, 1990; and Franzinelli and Latrubesse, 1993). 
AVERAGE DIP: Subvertical, to the northeast

SENSE OF MOVEMENT: Normal, down to the northeast

GEOMORPHIC EXPRESSION: There is a low scarp that marks the south border of the Branco River-Negro River depression. The fault exerts strong structural control of the enlarged valley (graben) of middle-lower Negro River, and it defines an impressive asymmetry of drainage.

\section{RECURRENCE INTERVAL: Unknown}

SLIP RATE: Unknown, probably $<1 \mathrm{~mm} / \mathrm{yr}$.

TIME OF MOST RECENT OF MOVEMENT: Quaternary (<1.6 Ma)

Comments: The seismicity (Assumpção and Suarez, 1988) and geomorphological observations (behavior of the alluvial filling at the confluence of the Branco and Negro rivers) suggest that the activity may have continued in the Holocene. However, no conclusive data exist to define young movement

\section{REFERENCES}

Assumpção, M., Suarez, G., and Veloso, J.A., 1985, Fault plane solutions of intraplate earthquakes in Brazil—Some constraints on the regional stress field: Tectonophysics, v. 113, p. 283-293.

Assumpção, M., e Suarez, G., 1988, Source mechanism of moderate size earthquakes e stress orientation in mid-plate South America: Geophysical Journal, v. 92, p. 253-267.

Bemerguy, R.L., e Sena Costa, J.B., 1991, Considerações sobre a evolução do sistema de drenagem da Amazônia e sua relação com o arcabouço tectônico-estrutural: Boletim do Museu Paraense Emílio Goeldi, Série Ciências da Terra, v. 3, p. 76-97.

Costa, J.B.S., Hasui, H., Borges, M. da S., Bemerguy, R.L., Saadi, A., e Costa Jr, R.S., 1994, Arcabouço tectônico MesoCenozóico da região da calha do Amazonas, in Simpósio de Geologia da Amazônia, 4, Belém, 1994: Anais Sociedade Brasileira de Geologia, Belém-NO, v. 1, p. 47-50.

Cunha, F.M.B. da, 1988, Controle tectônico-estrutural na hidrografia na região do Alto Amazonas, in Congresso Brasileiro de Geologia, 35, Bélem, 1988: Anais Sociedade Brasileira de Geologia, Belém-NO, v. 5, p. 2267-2273.

Cunha, F.M.B. da, 1991, Morfologia e neotectonismo do Rio Amazonas, in Simpósio de Geologia da Amazônia, 3, Belém, 1991: Anais Sociedade Brasileira de Geologia/Núcleo Norte, Belém-PA, p. 193-210.

Fernandes Filho, L.A.; Costa, J.B.S., e Costa, M.L., 1995, Bacia de Manaus-Uma estrutura pull-apart do Quaternário, in Simpósio Nacional de Estudos Tectónicos, 5, Gramado-RS, 1995: Sociedade Brasileira de Geologia, Porto Alegre -RSCPGQ/UFRGS, p. 419-420.

Franzinelli, E., e Piuci, J., 1988, Evidências de neotectonismo na Bacia Amazônica, in Congresso Latino-Americano de Geologia, 7, Belém, 1988: Anais Sociedade Brasileira de Geologia/Núcleo Norte, Belém-PA, p. 80-90.

Franzinelli, E., and Latrubesse, E., 1993, Neotectonics in the central part of the Amazon Basin: Bulletin of INQUA, Neotectonic Commission, v. 16, p. 10-13.

Igreja, H.L.S., e Franzinelli, E., 1987, Neotectônica; o lineamento Rio Negro, um exemplo: ICE Manaus, v. 4, p. 17-18.

Igreja, H.L.S., e Franzinelli, E., 1990, Estudos neotectônicos na região do Baixo Rio Negro - Centro-Nordeste do Estado do Amazonas, in Congresso Brasileiro de Geologia, 36, Natal, 1990: Anais Sociedade Brasileira de Geologia, Natal-RN, v. 5, p. 2099-2109.

Iriondo, M.H., and Suguio, K., 1981, Neotectonics of the Amazon Plain: Bulletin of INQUA, Neotectonic Commission, v. 4, p. 72-78.

Silva, C.L. da, Carvalho, J. da S., Alecrim, J.D., e Costa, S. Dos S., 1994, Considerações sobre neotectonismo na cidade de Manaus (AM) e áreas adjacentes, uma discussão preliminar, in Congresso Brasileiro de Geologia, 38, Balneário Camboriu, 1994: Anais Sociedade Brasileira de Geologia, Balneário Camboriu-SC, v. 2, p. 251-252.

Sternberg, H.O., 1950, Vales tectônicos na planície amazônica: Revista Brasileira de Geografia, Rio de Janeiro, v. 12 , no. 4, p. 3-26.

Sternberg, H.O., 1953, Sismicidade e morfologia na Amazônia Brasileira: Anais da Academia Brasileira de Ciências, v. 25, no. 4, p. 443-453. 


\section{BR-12, SERRA DO ESTRONDO FAULT ZONE}

FAULT NUMBER: BR-12

Comments: Shown as fault TOC-01 on initial compilation.

FAULT NAME: Serra do Estrondo (fault zone)

SYNOPSIS AND GEOLOGIC SETTING: The Serra do Estrondo fault zone is concordant with some of Precambrian structures of the Paraguay-Araguaia fold belt that were mobilized during the Brasiliano Orogenesis. The Serra do Estrondo fault forms the boundary between the Parnaíba Basin (Paleozoic-Mesozoic sedimentary basin) to the east and Amazon Craton to west in the state of Tocantins.

COMPILER AFFILIATION, AND DATE OF COMPILATION: Allaoua Saadi (Univ. Federal de Minas Gerais, Belo Horizonte, Brasil), March 1997.

TYPE OF STUDIES: Compilation of cartographic and bibliographic data.

FAULT GEOMETRY

LENGTH: $632 \mathrm{~km}$ end to end ( $636 \mathrm{~km}$ cumulative)

END POINTS: $5^{\circ} 39^{\prime} 25^{\prime \prime}$ S., $47^{\circ} 46^{\prime} 49^{\prime \prime}$ W.; $11^{\circ} 16^{\prime} 1^{\prime \prime}$ S., $48^{\circ} 28^{\prime} 41^{\prime \prime} \mathrm{W}$.

AVERAGE STRIKE: $7^{\circ}$

Comments: This north-trending fault zone is probably composed of two sections, having been slightly offset by a strike-slip fault that trends in a E-W direction. However, there is no reliable data on timing of movement.

AVERAGE DIP: Subvertical with inclination to west

SENSE OF MOVEMENT: Probably normal, down to the west

Comments: Sense of movement determined from interpretation of published data and analysis of regional geomorpholog data.

GEOMORPHIC EXPRESSION: Forms impressive fault scarps and sequences of crests of the "Serra do Estrondo", which separate the depressions of the Middle Araguaia and Lower Tocantins Rivers, both of which extend parallel in a N-S direction.

RECURRENCE INTERVAL: Unknown

SLIP RATE: Unknown, probably $<1 \mathrm{~mm} / \mathrm{yr}$.

TIME OF MOST RECENT OF MOVEMENT: Quaternary $(<1.6 \mathrm{Ma})$

Comments: Movement may have continued into the Holocene because the faults in this zone control the northern part of Bananal Graben, a Quaternary sedimentary basin that shows signs of active subsidence (this also relates to the Porangatu fault zone, BR-19). However, there is no reliable data for its precise timing.

\section{REFERENCES}

Almeida, F.F.M. de, 1959,Traços gerais da geomorfologia do Centro-Oeste Brasileiro, in Congresso Internacional de Geografia, Rio de Janeiro, 1959, Guia de Excursões N 1: CNG, Rio de Janeiro, 1959, p. 7-65.

Bezerra, P.E.L., 1996, Neotectônica e morfogênese da Região de Carolina (MA, TO), Bacia do Parnaíba, Belém-PA: Universidade Federal do Pará, Dissertação de Mestrado, 1996 (inédito).

Hales, F.W., 1981, Anomalias magnéticas de origem profunda na Fossa do Araguaia e no Pantanal—Suas implicações geológicas: Mineração e Metalurgia, Rio de Janeiro, v. 44, no. 425, p. 24-30.

Saadi, A., 1993, Neotectônica da Plataforma Brasileira-Esboço e interpretação preliminares: Geonomos, Belo HorizonteMG, v. 1, no. 1 , p. 1-15. 


\section{BR-13, MARAGOGIPE FAULT}

FAULT NUMBER: BR-13

Comments: Shown as fault BAH-01 on initial compilation.

FAULT NAME: Maragogipe

SYNOPSIS AND GEOLOGIC SETTING: The Maragogipe fault was formed in the Mesozoic by rifting related to the separation of Africa and South America. It establishes the west limit between Cretaceous sediment of the Tucano/Jatobá rift and crystalline Precambrian basement rocks.

COMPILER AFFILIATION, AND DATE OF COMPILATION: Allaoua Saadi (Univ. Federal de Minas Gerais, Belo Horizonte, Brasil), March 1997.

TYPE OF STUDIES: Compilation of cartographic and bibliographic data, as well as regional field data.

FAULT GEOMETRY

LENGTH: $157 \mathrm{~km}$ end to end (156 km cumulative)

END POINTS: $12^{\circ} 35^{\prime} 25^{\prime \prime}$ S., $38^{\circ} 42^{\prime} 11^{\prime \prime} \mathrm{W}$.; $13^{\circ} 54^{\prime} 54^{\prime \prime}$ S., $39^{\circ} 6^{\prime} 3^{\prime \prime} \mathrm{W}$.

AVERAGE STRIKE: $16^{\circ}$

Comments: Direction slightly sinuous.

AVERAGE DIP: Approximately $80^{\circ}$ to east

SENSE OF MOVEMENT: Normal, down to the east

GEOMORPHIC EXPRESSION: Forms original fault scarp on basement rock with a height that is locally more than 100 meters.

\section{RECURRENCE INTERVAL: Unknown}

SLIP RATE: Unknown, probably $<1 \mathrm{~mm} / \mathrm{yr}$.

TIME OF MOST RECENT OF MOVEMENT: Holocene and post glacial $(<15 \mathrm{ka})$

Comments: The timing was estimated from the morphology of the falt scarp, from rivers that have not adjusted to the local base levels recently imposed, and subsidence that is still active in the Todos os Santos Bay (Tricart

Cardoso da Silva 1968, Martin and others, 1980, 1986).

\section{REFERENCES}

Howard, A.D., 1962, Escarpa de linha de falha de Salvador: Boletim Técnico da PETROBRÁS, v. 5, no. 3., p. 59-63.

Martin, L., Bittencourt, A.C. da S.P., Vilas Boas, G. da S., e Flexor, J.M., 1980, Mapa Geológico do Quaternário Costeiro do Estado da Bahia (Texto Explicativo): Publ. da Coordenação da produção Mineral da Secretaria de Minas e Energia, do Governo do Estado da Bahia, Salvador, 57 pp., escala 1:250.000.

Martin, L., Flexor, J.M., Bittencourt, A.C. da S.P., and Dominguez, J.M.L., 1986, Neotectonic Movements on a Passive Continental Margin, Salvador Region, Brazil: Neotectonics-An International Journal of Crustal Dynamics, v. 1, p. 87-103.

Tricart, J., e Cardoso da Silva, T., 1968, Estudos de geomorfologia da Bahia e Sergipe: Publ. da Fundação para o Desenvolvimento da Ciência na Bahia, Salvador, 167 pp.

\section{BR-14, PÉ DE SERRA FAULT}

FAULT NUMBER: BR-14

Comments: Shown as fault BAH-02 on initial compilation.

FAULT NAME: Pé de Serra (fault) 
SYNOPSIS AND GEOLOGIC SETTING: The Pé de Serra fault affects cratonic basement rocks in the Setaneja Depression, in the central part of the state of Bahia. The fault forms the eastern border of the "Serra da Jacobina" and is a reactivated part of a larger thrust fault system of Proterozoic age.

COMPILER AFFILIATION, AND DATE OF COMPILATION: Allaoua Saadi (Univ. Federal de Minas Gerais, Belo Horizonte, Brasil), March 1997.

TYPE OF STUDIES: Compilation of cartographic and bibliographic data, and general field observations.

FAULT GEOMETRY

LENGTH: $128 \mathrm{~km}$ end to end (128 km cumulative)

END POINTS: $9^{\circ} 39^{\prime} 51^{\prime \prime}$ S., $39^{\circ} 26^{\prime} 50^{\prime \prime} \mathrm{W}$.; $10^{\circ} 43^{\prime} 7^{\prime \prime}$ S., $39^{\circ} 53^{\prime} 5^{\prime \prime} \mathrm{W}$.

AVERAGE STRIKE: $22^{\circ}$

Comments: The fault line is sinuous and its real limits exceed the listed endpoints. However, there is lack of data on the Cenozoic evolution of this area and thus the limits of the fault are poorly known.

AVERAGE DIP: Inclined to east, probably subvertical in subsurface

SENSE OF MOVEMENT: Normal

Comments: Sense considered to be normal in view of the few data that are available. Along its trace, sequences of alluvial fans are apparently interrupted by the fault. On the other hand, the fault controls the western border of a basin that is filled by Tertiary alluvial sediment (probably the Pliocene Capim Grosso Formation).

GEOMORPHIC EXPRESSION: The fault controls the alignment of the eastern margin of the "Serra da Jacobina" and exhibits discontinuous scarps that are marked by triangular and trapezoidal facets.

RECURRENCE INTERVAL: Unknown

SLIP RATE: Unknown, probably $<1 \mathrm{~mm} / \mathrm{yr}$.

TIME OF MOST RECENT OF MOVEMENT: Quaternary ( $<1.6 \mathrm{Ma})$

Comments: The general timing of movement is based on interpretation of geomorphological features and on the observation of faulting of sediments of the upper part of the Capim Grosso Formation (Pliocene?). Younger movement is suggested by the preservation of fault topography.

\section{REFERENCES}

Barbosa, J.S.F. (coord.), 1994, Mapa Geológico do estado da Bahia, Estado da Bahi: Secretaria de Indústria, Comércio e Turismo/Superintendência de Geologia e Recursos Minerais, escala 1:1,000,000.

\section{BR-15, SOBRAL-PEDRO II LINEAMENT}

FAULT NUMBER: BR-15

Comments: Shown as CEA-01 on initial compilation.

FAULT NAME: Sobral-Pedro II (lineament)

SYNOPSIS AND GEOLOGIC SETTING: The Sobral-Pedro II lineament is located in the northwest part of the state of Ceará (northern part of the Northeast Region). This fault zone probably formed during the early to middle Proterozoic and was reactivated during the Brasiliano Orogenesis with the accentuation of the Jaibaras Graben, which was filled by Paleozoic sediment. The Sobral-Pedro II lineament constitutes the northeast section of the Transbrasiliano lineament (crustal discontinuity of the two Brazils). (See also faults BR-19 and BR-22).

COMPILER AFFILIATION, AND DATE OF COMPILATION: Allaoua Saadi (Univ. Federal de Minas Gerais, Belo Horizonte, Brasil) and Joaquim Raul Torquato (Univ. Federal do Ceara, Fortaleza, Brasil), March 1997.

TYPE OF STUDIES: Regional morpho-neotectonic studies and field data. 
FAULT GEOMETRY

LENGTH: $155 \mathrm{~km}$ end to end (155 km cumulative)

END POINTS: $3^{\circ} 29^{\prime} 4^{\prime \prime}$ S., $39^{\circ} 9^{\prime} 12^{\prime \prime}$ W.; $4^{\circ} 32^{\prime} 34^{\prime \prime}$ S., $40^{\circ} 6^{\prime} 27^{\prime \prime} \mathrm{W}$.

AVERAGE STRIKE: $43^{\circ}$

AVERAGE DIP: Unknown

SENSE OF MOVEMENT: Probably right lateral (dextral) strike-slip

Comments: Sense of movement was determined from analyses of regional morpho-neotectonics and the neotectonic stress field of the northern part of the Northeast Region.

GEOMORPHIC EXPRESSION: Lineament is associated with fault-line scarps and exerts strong structural control on the valley of the Acarau River.

\section{RECURRENCE INTERVAL: Unknown}

SLIP RATE: Unknown, probably $<1 \mathrm{~mm} / \mathrm{yr}$.

TIME OF MOST RECENT OF MOVEMENT: Holocene and post glacial $(<15 \mathrm{ka})$

Comments: This interpretation is based on observed faulting of beach rock along the north coast of the state of Ceará.

\section{REFERENCES:}

Ferreira, J.M., 1983, Seismicity of northeastern Brazil: Universidade de São Paulo, São Paulo Dissertação de Mestrado (inédito).

Fortes, F.P., 1978, Geologia estrutural e tectônica da bacia sedimentar do Meio Norte do Brasil, in Congresso Brasileiro de Geologia, 30, Recife, 1978: Anais Sociedade Brasileira de Geologia, Recife-PE, v. 1, no. 1, p. 321-336.

Kegel, W., 1965, A estrutura geológica do Nordeste do Brasil: DNPM, Divisão de Geologia e Mineração, Boletim 227, 47 pp.

Moreira, M.M.M., e Gato, L.C.S., 1981, Geomorfologia in Brasil: DNPM. Projeto RADAMBRASIL, Folha SA-24, Fortaleza, Rio de Janeiro.

Saadi, A., e Torquato, J.R., 1992, Contribuição à Neotectônica do Estado do Ceará: Revista de Geologia, Universidade Federal do Ceará/Fortaleza, v. 5, no. 5, p. 5-38.

\section{BR-16, JAGUARIBE LINEAMENT}

FAULT NUMBER: BR-16

Comments: Shown as fault CEA-02 on initial compilation.

FAULT NAME: Jaguaribe (lineament)

SYNOPSIS AND GEOLOGIC SETTING: The Jaguaribe lineament is located in the northeast part of the state of Ceará (northern part of the Northeast Region), along the basin of the Lower Jaguaribe River. It is a shear zone that was probably formed during the early to middle Proterozoic and was reactivated during the Brasiliano Orogenesis and again in the Mesozoic, when it controlled the formation of several small sedimentary basins. The Jaguaribe lineament joins the Farias Brito fault (BR-17) on the south, and as such might represent a continuous structure.

COMPILER AFFILIATION, AND DATE OF COMPILATION: Allaoua Saadi (Univ. Federal de Minas Gerais, Belo Horizonte, Brasil) and Joaquim Raul Torquato (Univ. Federal do Ceara, Fortaleza, Brasil), March 1997.

TYPE OF STUDIES: Regional morpho-neotectonic study and field data.

\section{FAULT GEOMETRY}

LENGTH: $209 \mathrm{~km}$ end to end ( $210 \mathrm{~km}$ cumulative)

END POINTS: $4^{\circ} 37^{\prime} 36^{\prime \prime}$ S., $37^{\circ} 34^{\prime} 20^{\prime \prime} \mathrm{W}$.; $6^{\circ} 5^{\prime} 11^{\prime \prime}$ S., $38^{\circ} 45^{\prime} 30^{\prime \prime} \mathrm{W}$.

AVERAGE STRIKE: $39^{\circ}$ 
Comments: The endpoints and strike are related to the main trace of the fault zone, which is very wide.

AVERAGE DIP: Unknown

SENSE OF MOVEMENT: Probably right lateral (dextral) strike-slip with normal component.

Comments: Sense of movement based on criteria of regional morpho-neotectonic analysis and the neotectonic stress field of the northern part of the Northeast Region.

GEOMORPHIC EXPRESSION: The Jaguaribe lineament controls the fluvial depression of Lower Jaguaribe River, the margins of this river, and forms small scarps and crests.

\section{RECURRENCE INTERVAL: Unknown}

SLIP RATE: Unknown, probably $<1 \mathrm{~mm} / \mathrm{yr}$.

TIME OF MOST RECENT OF MOVEMENT: Quaternary $(<1.6 \mathrm{Ma})$

Comments: Timing based on faults displacements that affect graben sediment of the Tertiary Barreiras Group and structural control of Pleistocene fluvial sedimentation. Future dating may confirm activity during the Holocene.

\section{REFERENCES}

Assumpção, M., Ferreira, J.M., Carvalho, J.M., Blum, M.L., Menezes, E.A., Fontenele, D., and Aires, A., 1989, Seismic activity in Palhano, CE, October, 1988-Preliminary results: Revista Brasileira de Geofísica, São Paulo-SP, v. 7, no. 1, p. 11-17.

Ferreira, J.M., 1983, Seismicity of northeastern Brazil: Universidade de São Paulo, São Paulo-SP, Dissertação de Mestrado (inédito).

Maia, L.P., Morais, J.O. de, and Torquato, J.R., 1993, Applied geophysics to neotectonics in Aracati-ceará Region, Northeastern Brazil: Revista de Geologia, Universidade Federal do Ceará/Fortaleza, v. 6, p. 57-64.

Moreira, M.M.M., e Gato, L.C.S., 1981, Geomorfologia in Brasil: DNPM Projeto RADAMBRASIL, Folha SA-24, Fortaleza, Rio de Janeiro, Brazil.

Saadi, A., e Torquato, J.R., 1992, Contribuição à Neotectônica do Estado do Ceará: Revista de Geologia, Universidade Federal do Ceará/Fortaleza, v. 5, no. 5, p. 5-38.

Torquato, J.R., Torquato, A.M.P, e Moraes, R.M. de, 1996, Alguns aspectos neotectônicos da região litorânea compreendida entre o Sítio Retirinho e Ponta Grossa (Ceará), in Congresso Brasileiro de Geologia, 39, Salvador, 1996: Anais Sociedade Brasileira de Geologia, Salvador-BA, v. 5, p. 470-473.

\section{BR-17, FARIAS BRITO FAULT}

FAULT NUMBER: BR-17

Comments: Shown as fault CEA-03 on initial compilation.

FAULT NAME: Farias Brito (fault)

SYNOPSIS AND GEOLOGIC SETTING: The Farias Brito fault is located in the southern part of the state of Ceará (part of the Northeast Region) along the basin of middle Upper Jaguaribe River. It is a shear zone that was probably formed during the early to middle Proterozoic and was reactivated during the Brasiliano Orogenesis and again in the Mesozoic, when it controlled the formation of several small sedimentary basins. The Farias Brito fault joins the Jaguaribe lineament (BR-16) on the north, and as such might represent a continuous structure.

COMPILER AFFILIATION, AND DATE OF COMPILATION: Allaoua Saadi (Univ. Federal de Minas Gerais, Belo Horizonte, Brasil) and Joaquim Raul Torquato (Univ. Federal do Ceara, Fortaleza, Brasil), March 1997.

TYPE OF STUDIES: Regional morpho-neotectonic study and field data.

\section{FAULT GEOMETRY}

LENGTH: $190 \mathrm{~km}$ end to end (192 km cumulative)

END POINTS: $6^{\circ} 8^{\prime} 54^{\prime \prime}$ S., $38^{\circ} 46^{\prime} 58^{\prime \prime}$ W.; 6 $6^{\circ} 54^{\prime} 49^{\prime \prime}$ S., $40^{\circ} 18^{\prime} 44^{\prime \prime} \mathrm{W}$.

AVERAGE STRIKE: $63^{\circ}$ 
AVERAGE DIP: Unknown

SENSE OF MOVEMENT: Probably right lateral (dextral) strike-slip.

Comments: Sense of movement is based on analysis of regional morpho-neotectonics and on the neotectonic stress field of the northern part of the Northeast Region.

GEOMORPHIC EXPRESSION: Crests and aligned depressions.

RECURRENCE INTERVAL: Unknown

SLIP RATE: Unknown, probably $<1 \mathrm{~mm} / \mathrm{yr}$.

TIME OF MOST RECENT OF MOVEMENT: Quaternary $(<1.6 \mathrm{Ma})$

\section{REFERENCES}

Ferreira, J.M., 1983, Seismicity of northeastern Brazil: Universidade de São Paulo, São Paulo-SP, Dissertação de Mestrado (inédito).

Moreira, M.M.M., e Gato, L.C.S., 1981, Geomorfologia in Brasil: DNPM Projeto RADAMBRASIL, Folha SA-24, Fortaleza, Rio de Janeiro.

Saadi, A., e Torquato, J.R., 1992, Contribuição à Neotectônica do Estado do Ceará: Revista de Geologia, Universidade Federal do Ceará/Fortaleza, v. 5, no. 5, p. 5-38.

\section{BR-18, ARNEIROZ-SENADOR POMPEU FAULT}

FAULT NUMBER: BR-18

Comments: Shown as fault CEA-04 on initial compilation

FAULT NAME: Arneiroz-Senador Pompeu (fault)

SYNOPSIS AND GEOLOGIC SETTING: The Arneiroz-Senador Pompeu fault is located in the central part of the state of Ceará (northern part of the Northeast Region), along the basin of the Banabuiu River. It is a shear zone that was probably formed during the early to middle Proterozoic and was reactivated during the Brasiliano Orogenesis and again in the Mesozoic, when it controlled post-tectonic granitic intrusions.

COMPILER AFFILIATION, AND DATE OF COMPILATION: Allaoua Saadi (Univ. Federal de Minas Gerais, Belo Horizonte, Brasil) and Joaquim Raul Torquato (Univ. Federal do Ceara, Fortaleza, Brasil), March 1997.

TYPE OF STUDIES: Regional morpho-neotectonic study and field data.

\section{FAULT GEOMETRY}

LENGTH: $386 \mathrm{~km}$ end to end ( $387 \mathrm{~km}$ cumulative)

END POINTS: $4^{\circ} 11^{\prime} 22^{\prime \prime}$ S., $38^{\circ} 1^{\prime} 15^{\prime \prime} \mathrm{W}$.; 6 $6^{\circ} 25^{\prime} 54^{\prime \prime}$ S., $40^{\circ} 40^{\prime} 77^{\prime \prime} \mathrm{W}$.

AVERAGE STRIKE: $50^{\circ}$

AVERAGE DIP: Unknown

SENSE OF MOVEMENT: Probably right lateral (dextral) strike-slip.

Comments: Sense of movement is based on analysis of regional morpho-neotectonics and on the neotectonic stress field of the northern part of the Northeast Region.

GEOMORPHIC EXPRESSION: Fault controls linear course of the Banabuiu River, crests in the Arneiroz region, and division of the drainage in the basins of the Banabuiu and Jaguaribe Rivers.

RECURRENCE INTERVAL: Unknown

SLIP RATE: Unknown, probably $<1 \mathrm{~mm} / \mathrm{yr}$.

TIME OF MOST RECENT OF MOVEMENT: Quaternary (<1.6 Ma)

\section{REFERENCES}


Ferreira, J.M., 1983, Seismicity of northeastern Brazil: Universidade de São Paulo, São Paulo-SP, Dissertação de Mestrado (inédito).

Moreira, M.M.M., e Gato, L.C.S., 1981, Geomorfologia in Brasil: DNPM Projeto RADAMBRASIL, Folha SA-24, Fortaleza, Rio de Janeiro.

Saadi, A., e Torquato, J.R., 1992, Contribuição à Neotectônica do Estado do Ceará: Revista de Geologia, Universidade Federal do Ceará/Fortaleza, v. 5, no. 5, p. 5-38.

\section{BR-19, PORANGATU FAULT ZONE}

FAULT NUMBER: BR-19

Comments: Shown as fault GOI-01 on initial compilation.

FAULT NAME: Porangatu (fault zone)

SYNOPSIS AND GEOLOGIC SETTING: The Porangatu fault zone is an ancient shear zone that was probably formed during the early to middle Proterozoic and was reactivated during the Brasiliano Orogenesis and again in the Mesozoic. It is located on the western margin of the "Maciço Mediano de Goiás", in the central-western region of Brazil. It forms the limit between the higher regions of the "Planalto Central de Goiás" and the Upper Araguaia River depression. It is the central, more representative, section of the Transbrasiliano lineament (crustal discontinuity of the two Brazils). (Also see faults BR-15 and BR-22).

COMPILER AFFILIATION, AND DATE OF COMPILATION: Allaoua Saadi (Univ. Federal de Minas Gerais, Belo Horizonte, Brasil), March 1997.

TYPE OF STUDIES: Compilation of cartographic and bibliographic data.

FAULT GEOMETRY

LENGTH: $669 \mathrm{~km}$ end to end ( $673 \mathrm{~km}$ cumulative)

END POINTS: $11^{\circ} 24^{\prime} 7^{\prime \prime}$ S., $48^{\circ} 25^{\prime} 45^{\prime \prime}$ W.; $16^{\circ} 3^{\prime} 54^{\prime \prime}$ S., $52^{\circ} 5^{\prime} 26^{\prime \prime} \mathrm{W}$.

AVERAGE STRIKE: $38^{\circ}$

AVERAGE DIP: Unknown

SENSE OF MOVEMENT: Probably right lateral (dextral) strike-slip, with vertical component.

Comments: Locally has vertical component. Sense of movement is based predominantly on regional analysis of geomorphological data.

GEOMORPHIC EXPRESSION: Forms scarps of the "Serra Dourada", which is the western edge of the "Planalto Central de Goiás". Causes a reorientation of the whole basin drainage of the upper Araguaia River and, consequently, controls the southeastern border of the Bananal Graben (a Quaternary sedimentary basin).

\section{RECURRENCE INTERVAL: Unknown}

SLIP RATE: Unknown, probably $<1 \mathrm{~mm} / \mathrm{yr}$.

TIME OF MOST RECENT OF MOVEMENT: Quaternary $(<1.6 \mathrm{Ma})$

Comments: Although Quaternary, movement probably continued during the Holocene, as suggested by the hydrological and sedimentary regime in the area of the Bananal Graben ("Ilha do Bananal"). This is characterized by retention of water and sediment and indications of active subsidence as in the Pantanal Basin.

\section{REFERENCES}

Almeida, F.F.M. de, 1959, Traços gerais da geomorfologia do Centro-Oeste Brasileiro, in Congresso Internacional de Geografia, Rio de Janeiro, 1959, Guia de Excursões. N 1: CNG, Rio de Janeiro, 1959, p. 7-65.

Hales, F.W., 1981, Anomalias magnéticas de origem profunda na Fossa do Araguaia e no Pantanal—Suas implicações geológicas: Mineração e Metalurgia, Rio de Janeiro, v. 44, no. 425, p. 24-30.

Hasui, Y., e Mioto, J.A., 1988, A zona sismogênica de Porangatu, in Congresso Brasileiro de Geologia, 35, Belém, 1988: Anais Sociedade Brasileira de Geologia, Belém-NO, v. 5, p. 2173-2186. 
Fortes, F.P., 1978, Geologia estrutural e tectônica da bacia sedimentar do Meio Norte do Brasil, in Congresso Brasileiro de Geologia, 30, Recife, 1978: Anais Sociedade Brasileira de Geologia, Recife-PE, v. 1, no. 1, p. 321-336.

Saadi, A., 1993, Neotectônica da Plataforma Brasileira-Esboço e interpretação preliminares: Geonomos, Belo HorizonteMG, v. 1, no. 1, p. 1-15.

\section{BR-20, GURUPI FAULT}

FAULT NUMBER: BR-20

Comments: Shown as fault MAR-01 on initial compilation.

FAULT NAME: Gurupi

SYNOPSIS AND GEOLOGIC SETTING: The Gurupi fault is located in the northern part of the state of Maranhão (northern part of the Northeast Region). It is in the northern part of the Parnaíba Basin (Paleozoic-Mesozoic). More specifically, it defines the Mesozoic to Cenozoic age Barreirinhas Basin.

COMPILER AFFILIATION, AND DATE OF COMPILATION: Allaoua Saadi (Univ. Federal de Minas Gerais, Belo Horizonte, Brasil), March 1997.

TYPE OF STUDIES: Compilation of cartographic and bibliographic data.

FAULT GEOMETRY

LENGTH: $430 \mathrm{~km}$ end to end (433 km cumulative)

END POINTS: $0^{\circ} 50^{\prime} 46^{\prime \prime}$ S., $47^{\circ} 35^{\prime} 26^{\prime \prime} \mathrm{W}$.; $3^{\circ} 9^{\prime} 16^{\prime \prime}$ S., 44 $28^{\prime} 56^{\prime \prime} \mathrm{W}$.

AVERAGE STRIKE: $-54^{\circ}$

Comments: The fault strike is slightly sinuous.

AVERAGE DIP: Unknown angle to the northeast?

SENSE OF MOVEMENT: Normal, down to the northeast

GEOMORPHIC EXPRESSION: Very weakly expressed as deflections of rivers and slight steps that form drainage divides.

\section{RECURRENCE INTERVAL: Unknown}

SLIP RATE: Unknown, probably $<1 \mathrm{~mm} / \mathrm{yr}$.

TIME OF MOST RECENT OF MOVEMENT: Quaternary (<1.6 Ma)

Comments: Timing is based on the fault's influence on Quaternary sedimentation in the downdropped coastal block.

\section{REFERENCES}

Ackermann, F.L., 1964, Geologia e fisiografia da Região Bragantina-Estado do Pará: Boletim do INPA, Manaus, v. 21, p. $1-90$.

Bezerra, P.E.L., e Costa, J.B.S., 1996, Compartimentação estrutural neotectônica da região de Carolina (MA/TO), Bacia do Parnaíba, in Simpósio de Geologia da Amazônia, 5, Belém-PA, 1996: Anais Sociedade Brasileira de Geologia/Núcleo Norte, Belém-PA, p. 320-322.

Ferreira Jr., C.R.P., 1996, Neotectônica na Bacia de São Luis: Universidade Federal do Pará, Centro de Geociências, Dissertação de Mestrado (Inédito).

Petri, S., 1952, Foraminíferos miocênicos da Formação Pirabas: Boletim da Faculdade de Filosofia, Ciências e Letras/Universidade de São Paulo, São Paulo, v. 216, p. 1-79.

Saadi, A., 1993, Neotectônica da Plataforma Brasileira-Esboço e interpretação preliminares: Geonomos, Belo HorizonteMG, v. 1, no. 1 , p. 1-15.

\section{BR-21, SOBRADINHO FAULT ZONE}


FAULT NUMBER: BR-21

Comments: Shown as fault MAR-02 on initial compilation.

FAULT NAME: Sobradinho (fault zone)

SYNOPSIS AND GEOLOGIC SETTING: The Sobradinho fault zone is located in the north of the state of Maranhão (northern part of the Northeast Region). It is on the northern border of the Parnaíba Basin (PaleozoicMesozoic). More specifically, it defines the Barreirinhas Basin (Mesozoic-Cenozoic).

COMPILER AFFILIATION, AND DATE OF COMPILATION: Allaoua Saadi (Univ. Federal de Minas Gerais, Belo Horizonte, Brasil), March 1997.

TYPE OF STUDIES: Compilation of cartographic and bibliographic data.

FAULT GEOMETRY:

LENGTH: $299 \mathrm{~km}$ end to end (302 km cumulative)

END POINTS: $3^{\circ} 10^{\prime} 19^{\prime \prime}$ S., $44^{\circ} 21^{\prime} 29^{\prime \prime} \mathrm{W}$.; $3^{\circ} 16^{\prime} 07^{\prime \prime}$ S., $41^{\circ} 40^{\prime} 40^{\prime \prime} \mathrm{W}$.

AVERAGE STRIKE: $-88^{\circ}$

AVERAGE DIP: Unknown angle to the north?

SENSE OF MOVEMENT: Normal, down to the north.

GEOMORPHIC EXPRESSION: It is very weakly expressed by alignments of hills and deflections of rivers.

RECURRENCE INTERVAL: Unknown

SLIP RATE: probably $<1 \mathrm{~mm} / \mathrm{yr}$.

TIME OF MOST RECENT OF MOVEMENT: Quaternary (<1.6 Ma)

\section{REFERENCES}

Ackermann, F.L., 1964, Geologia e fisiografia da Região Bragantina-Estado do Pará: Boletim do INPA, Manaus, v. 21, p. $1-90$.

Bezerra, P.E.L., e Costa, J.B.S., 1996, Compartimentação estrutural neotectônica da região de Carolina (MA/TO), Bacia do Parnaíba, in Simpósio de Geologia da Amazônia, 5, Belém-PA, 1996: Anais Sociedade Brasileira de Geologia/Núcleo Norte, Belém-PA, p. 320-322.

Ferreira Jr., C.R.P., 1996, Neotectônica na Bacia de São Luis: Universidade Federal do Pará, Centro de Geociências, Dissertação de Mestrado (Inédito).

Petri, S., 1952, Foraminíferos miocênicos da Formação Pirabas: Boletim da Faculdade de Filosofia, Ciências e Letras/Universidade de São Paulo, São Paulo, v. 216, p. 1-79.

Saadi, A., 1993, Neotectônica da Plataforma Brasileira-Esboço e interpretação preliminares: Geonomos, Belo HorizonteMG, v. 1, no. 1 , p. 1-15.

\section{BR-22, COXIM FAULT}

FAULT NUMBER: BR-22

Comments: Shown as fault MAT-01 on initial compilation.

FAULT NAME: Coxim (fault)

SYNOPSIS AND GEOLOGIC SETTING: The Coxim fault is located in the central-western region of Brazil (state of Mato Grosso do Sul). It controls the east border of the Pantanal Basin, a sedimentary basin of Quaternary age in which approximately 400 meters of fluvial and possibly, lacustrine sediment have accumulated. It also controls the scarp that forms the western border of the Paraná Basin in a intracontinental sedimentary basin of PaleozoicMesozoic age. It is the southern section of the Transbrasiliano lineament (crustal discontinuity of the two Brazils). (See also faults BR-15 and BR-19). 
COMPILER AFFILIATION, AND DATE OF COMPILATION: Allaoua Saadi (Univ. Federal de Minas Gerais, Belo Horizonte, Brasil), March 1997.

TYPE OF STUDIES: Compilation of cartographic and bibliographic data, as well as regional field data.

\section{FAULT GEOMETRY}

LENGTH: $499 \mathrm{~km}$ end to end (501 km cumulative)

END POINTS: $18^{\circ} 54^{\prime} 26^{\prime \prime}$ S., $54^{\circ} 57^{\prime} 11^{\prime \prime} \mathrm{W} . ; 22^{\circ} 30^{\prime} 52^{\prime \prime}$ S., $57^{\circ} 16^{\prime} 7^{\prime \prime} \mathrm{W}$.

AVERAGE STRIKE: $31^{\circ}$

Comments: It probably has a N-S branch that controls the remainder of the scarp of the "Chapada dos

Guimarães". However, there is no conclusive data to prove this branch.

AVERAGE DIP: Probably subvertical

SENSE OF MOVEMENT: Probably normal

Comments: Movement could be right lateral (dextral) strike-slip with a normal component.

GEOMORPHIC EXPRESSION: It is represented by the "Serra do Maracaju" and by the "Serra de São Gerônimo".

\section{RECURRENCE INTERVAL: Unknown}

SLIP RATE: Unknown, probably $<1 \mathrm{~mm} / \mathrm{yr}$.

TIME OF MOST RECENT OF MOVEMENT: Quaternary (<1.6 Ma)

Comments: The timing was determined from the age of the sediment that fills the Pantanal Basin. Hydrological and sedimentary features of the basin indicate active subsidence, so movement probably continued into the Holocene.

\section{REFERENCES}

Almeida, F.F.M. de, 1959, Traços gerais da geomorfologia do Centro-Oeste Brasileiro, in Congresso Internacional de Geografia, Rio de Janeiro, 1959, Guia de Excursões $N^{\circ}$ 1: CNG, Rio de Janeiro, p. 7-65.

Davino, A., 1968, Determinação de espessuras do sedimentos do Pantanal Matogrossense por sondagens elétricas: Rio de Janeiro, Anais da Academia Brasileira de Ciências, v. 40, no. 3, p. 327-330.

DNOS/Brasil, 1974, Estudos hidrológicos da Bacia do Alto Paraguai, relatório técnico: Rio de Janeiro, Departamento Nacional de Obras e Saneamento, v. 1, 1974.

Fortes, F.P., 1978, Geologia estrutural e tectônica da bacia sedimentar do Meio Norte do Brasil, in Congresso Brasileiro de Geologia, 30, Recife, 1978: Anais Sociedade Brasileira de Geologia, Recife-PE, v. 1, no. 1, p. 321-336.

Hales, F.W., 1981, Anomalias magnéticas de origem profunda na Fossa do Araguaia e no Pantanal—Suas implicações geológicas: Mineração e Metalurgia, Rio de Janeiro, v. 44, no. 425, p. 24-30.

Saadi, A., 1993, Neotectônica da Plataforma Brasileira-Esboço e interpretação preliminares: Geonomos, Belo HorizonteMG, v. 1, no. 1, p. 1-15.

Weyler, G., 1962, Projeto Pantanal: Relatório final dos poços perfurados no Pantanal Matogrossense: Ponta Grossa-PR, Petrobràs/DEBSP.

Weyler, G., 1964, Projeto Pantanal: Relatório final de abandono dos poços SBst-1 A-MT (São Bento), FPst-1 A-MT (Fazenda Piquiri) e Lcst-1 A-MT (Lagoa do Cascavel): Ponta Grossa-PR, Petrobràs/DEBSP.

\section{BR-23, UPPER GRANDE RIVER CRUSTAL DISCONTINUITY (DCARG)}

FAULT NUMBER: BR-23

Comments: Shown as fault MGE-01 on initial compilation.

FAULT NAME: Upper Rio Grande (crustal discontinuity)

Comments: Also known as DCARG-Upper Grande River crustal discontinuity (shear zone) (Saadi, 1991).

SYNOPSIS AND GEOLOGIC SETTING: The DCARG is a shear zone that forms part of the Ouro Fino shear belt ("Zona Rúptil Carandaí-Mogí-Guaçu"; Wernick and others, 1981), of Precambrian age. The DCARG is 
composed of several faults of mixed character; that is, strike-slip and reverse. This shear zone establishes the limit among the Craton of São Francisco (CSF) and the mobile belts of the southern part of the state of Minas Gerais: they probably formed during the early to middle Proterozoic and were reactivated during the Brasiliano Orogenesis (Neoproterozoic). The DCARG corresponds to the "Zona de Transcorrências Três Corações-São João Del Rei" (Hasui and others, 1990) and is the most well defined fault zone within the Precambrian belt. In the area of São João del Rei, a region of strong neotectonic expression, the DCARG has a width of $2 \mathrm{~km}$, sheltering a system of tectonic basins whose formation began in the early Miocene (Continental Rift of São João del Rei Region; Saadi, 1990).

COMPILER AFFILIATION, AND DATE OF COMPILATION: Allaoua Saadi (Univ. Federal de Minas Gerais, Belo Horizonte, Brasil), March 1997.

TYPE OF STUDIES: Morpho-neotectonic studies with detailed mapping and field analysis of deformation.

FAULT GEOMETRY

LENGTH: $501 \mathrm{~km}$ end to end (503 km cumulative)

END POINTS: $21^{\circ} 11^{\prime} 25^{\prime \prime}$ S., $43^{\circ} 30^{\prime}$ 6" W.; $23^{\circ} 43^{\prime} 7^{\prime \prime}$ S., $47^{\circ} 5^{\prime} 6^{\prime \prime} \mathrm{W}$.

Comments: These coordinates correspond to the main fault line.

AVERAGE STRIKE: $53^{\circ}$

AVERAGE DIP: Vertical at surface

SENSE OF MOVEMENT: Right lateral (dextral) strike-slip

Comments: The sense of movement was based on analysis of neotectonic stress fields.

GEOMORPHIC EXPRESSION: The shear zone's expression includes scarps on several types of rocks along the main faults, depressions filled by Tertiary and Quaternary sediment, and a dome corresponding to a zone of tectonic inversion. The shear zone (fault) controls fluvial basins, alluvial plains, and zones of accelerated erosion.

\section{RECURRENCE INTERVAL: Unknown}

SLIP RATE: Unknown, probably $<1 \mathrm{~mm} / \mathrm{yr}$.

TIME OF MOST RECENT OF MOVEMENT: Holocene and post glacial $(<15 \mathrm{ka})$

Comments: The timing was estimated from the relationship of the general geomorphology including control of subsidence of Holocene flood plains.

\section{REFERENCES:}

Hasui, Y., Ebert, H.D., e Sena Costa, J.B., 1990, Estruturação da extremidade oriental da Cunha de Guaxupé—Dados preliminares, in Congresso Brasileiro de Geologia, 36, Natal-RN, 1990: Anais Sociedade Brasileira de Geologia, Natal-RN, v. 5, p. 2099-2109.

Leite, E.C., Costa, R.D., e Saadi, A., 1995, Uma evidência de regime compressivo no Domo de São Sebastião da VitóriaMG, in Simpósio Nacional de Estudos Tectônicos, 5, Gramado-RS, 1995: Anais Sociedade Brasileira de Geologia, Porto Alegre-RS, p. 429-431.

Saadi, A., 1990, Um rift neocenozóico na região de São João del Rei-MG, borda sul do Cráton do São Francisco, in Workshop Neotecto. Sedim. Cont. Cenoz. SE Bras., 1, Belo Horizonte, 1990: Anais Sociedade Brasileira de Geologia, Belo Horizonte -MG, v. 11, p. 81-99.

Saadi, A., 1991, Ensaio sobre a morfotectônica de Minas Gerais-Tensões Intraplaca, Descontinuidades Crustais e Morfogênese, Belo Horizonte-MG: Universidade Federal de Minas Gerais, Instituto de Geociências, Tese para admissão a cargo de Professor Titular (inédito).

Saadi, A., 1992, A zona transpressiva de São Sebastião da Vitória, no "rift cenozóico de São João del Rei-MG" e feições neotectônicas associadas in Congresso Brasileiro de Geologia, 37. São Paulo, 1992: Anais Sociedade Brasileira de Geologia, São Paulo, v. 1, p. 602-603.

Saadi, A., 1993, Neotectônica da Plataforma Brasileira—Esboço e interpretação preliminares: Geonomos, Belo HorizonteMG, v. 1, no. 1, p. 1-15. 
Saadi, A., e Valadão, R.C., 1990, Eventos tectono-sedimentares na Bacia Cenozóica de Rio das Mortes (região de São João del Rei), in Workshop Neotecto. Sedim. Cont. Cenoz. SE Bras., 1, Belo Horizonte, 1990: Anais Sociedade Brasileira de Geologia, Belo Horizonte-MG, v. 11, p. 81-99.

Wernick, E., Fiori, A.P., Bettencourt, J.S., e Choudhouri, A., 1981, A tectônica rígida do fim do Ciclo Brasiliano e sua implicação na estruturação da borda sul e sudoeste do Cráton do São Francisco-Tentativa de um modelo preliminar, in Simp. Sobre o Cráton do São Francisco e Suas Faixas Marginais, 1, Salvador-BA, 1979: Anais Sociedade Brasileira de Geologia/Núcleo Nordeste, Salvador-BA, p. 164-168.

\section{BR-24, RIO ARAÇUAÍ FAULT}

\section{FAULT NUMBER: BR-24}

Comments: Shown as fault MGE-02 on initial compilation.

FAULT NAME: Rio Araçuaí (fault)

SYNOPSIS AND GEOLOGIC SETTING: The Araçuai River fault is a normal fault that controls a margin of the middle Jequitinhonha graben (Pliocene?) where it presents a maximum displacement of $100 \mathrm{~m}$. This fault results from reativation of the southern margin of the Taiobeiras fault, which is a Neoproterozoic thrust with E over W movement (Brasiliano Orogenesis) that affected schists and quartzites of the Salinas Formation (Macaúbas Group, Middle Proterozoic) and defined the eastern border of the "Serra do Espinhaço Setentrional." The graben that is partly controlled by this fault contains $100 \mathrm{~m}$ of alluvial sediment (São Domingos Formation, Pliocene?) and was uplifted within the whole area. The current drainage has cut below the base of the Pliocene sediment, indicating probable Quaternary uplift. In the area of confluence of the Jequitinhonha and Araçuaí rivers, the Araçuaí River fault has deformed the fluvial gravel of the lower terraces of the Araçuaí River (late to middle Pleistocene). In this case, the fault shows a perfect alignment to the foliation planes of the schists of the Salinas Formation.

COMPILER AFFILIATION, AND DATE OF COMPILATION: Allaoua Saadi (Univ. Federal de Minas gerais, Belo Horizonte, Brasil), March 1997.

TYPE OF STUDIES: Morpho-neotectonic studies with detailed mapping and analysis of deformations in the field.

FAULT GEOMETRY

LENGTH: $639 \mathrm{~km}$ end to end ( $636 \mathrm{~km}$ cumulative)

END POINTS: $13^{\circ} 42^{\prime} 14^{\prime \prime}$ S., $39^{\circ} 24^{\prime} 55^{\prime \prime} \mathrm{W} . ; 18^{\circ} 3^{\prime} 37^{\prime \prime}$ S., $42^{\circ} 58^{\prime} 11^{\prime \prime} \mathrm{W}$.

AVERAGE STRIKE: $38^{\circ}$

AVERAGE DIP: About $80^{\circ} \mathrm{E}$ at surface

SENSE OF MOVEMENT: Normal probably with main strike-slip component.

GEOMORPHIC EXPRESSION: The fault is expressed differently along its southern and northern parts. One the south, the scarp has a maximum height of $200 \mathrm{~m}$ (it corresponds to the eastern border of "Chapada de Acauá") and forms a strongly entrenched, linear (NE-SW) fault line-valley (Upper Araçuai River). On the north, the fault controls the confluence of the Jequitinhonha and Araçuai rivers. A lineament that corresponds with the fault is quite well expressed on topographic maps (1:100,000 and 1:250,000 scales), as well as on the Landsat/TM and SLAR (radar) images.

\section{RECURRENCE INTERVAL: Unknown.}

SLIP RATE: Unknown, probably $<1 \mathrm{~mm} / \mathrm{yr}$.

TIME OF MOST RECENT OF MOVEMENT: Quaternary (<1.6 Ma)

Comments: Timing based on faulting that affects alluvial sediment (gravel) that forms the lower terraces of the Araçuai River.

\section{REFERENCES}


Pedrosa Soares, A.C., e Saadi, A., 1989, O segmento meridional da Falha de Taiobeiras, MG, in Simpósio de Geologia de Minas Gerais, 5, Belo Horizonte, 1989: Anais Sociedade Brasileira de Geologia, Belo Horizonte-MG, v. 10, p. 161165 .

Saadi, A., 1991, Ensaio sobre a morfotectônica de Minas Gerais-Tensões Intraplaca, Descontinuidades Crustais e Morfogênese, Belo Horizonte-MG: Universidade Federal de Minas Gerais, Instituto de Geociências, Tese para admissão a cargo de Professor Titular (inédito).

Saadi, A., 1993, Neotectônica da Plataforma Brasileira-Esboço e interpretação preliminares: Geonomos, Belo HorizonteMG, v. 1, no. 1, p. 1-15.

Saadi, A., 1994, A Descontinuidade Crustal Minas-Alagoas-Uma faixa rúptil ativa durante o Cenozóico, in Congresso Brasileiro de Geologia, 38, Balneário Camboriú, 1994: Anais Sociedade Brasileira de Geologia, Balneário CamboriúSC, v. 2, p. 256-257.

Saadi, A., 1995, Geomorfologia da Serra do Espinhaço em Minas Gerais e de suas margens: Geonomos, Belo Horizonte-MG, v. 3, no. 1, p. 41-63.

Saadi, A., Pedrosa-Soares, A.C., 1990, Um graben cenozóico no Médio Jequitinhonha, Minas Gerais., in Workshop Neotect. Sedim. Cont. Cenoz. SE Bras., 1, Belo Horizonte, 1990: Anais Sociedade Brasileira de Geologia, Belo Horizonte -MG, v. 11, p. 101-124.

\section{BR-25, UPPER SÃO FRANCISCO RIVER CRUSTAL DISCONTINUITY (DCARSF)}

\section{FAULT NUMBER: BR-25}

Comments: Shown as fault MGE-03 on initial compilation.

FAULT NAME: Upper Rio São Francisco (crustal discontinuity)

Comments: Also known as the DCARSF-Upper São Francisco River crustal discontinuity (shear zone).

SYNOPSIS AND GEOLOGIC SETTING: The DCARSF is a NW-trending shear zone that is as much as $50 \mathrm{~km}$ in width. It formed in the Paleoproterozoic along the south portion of the São Francisco-CSF craton, where it controlled intrusion of metadiabasic dikes. To the northwest, it cuts out the Proterozoic fold belts in the states of Minas Gerais (MG) and Goiás (GO). The DCARSF was reactivated in the Mesozoic, preserving remnants of Cretaceous sediment in small grabens in MG, and controlling the occurrence of Mezosoic magmatic intrusions and associated zones of hydrothermal activity in the western part of the state of Minas Gerais and in the state of Goiás (Caldas Novas, Hidrolândia, and Catalão, GO; Patrocínio and Bambui, MG, etc.).

COMPILER AFFILIATION, AND DATE OF COMPILATION: Allaoua Saadi (Univ. Federal de Minas Gerais, Belo Horizonte, Brasil), March 1997.

TYPE OF STUDIES: Morpho-neotectonic studies, with detailed mapping, and analysis of deformation in the field.

FAULT GEOMETRY:

END POINTS: $17^{\circ} 52^{\prime} 42^{\prime \prime}$ S., $48^{\circ} 25^{\prime} 37^{\prime \prime} \mathrm{W} . ; 21^{\circ} 39^{\prime} 18^{\prime \prime} \mathrm{S} ., 44^{\circ} 27^{\prime} 26^{\prime \prime} \mathrm{W}$.

The coordinates correspond to the most probable ends of the whole shear-zone. In the state of Minas Gerais, its southeast limit is well established but its northwest limit is poorly known.

AVERAGE STRIKE: $-45^{\circ}$

AVERAGE DIP: Vertical

SENSE OF MOVEMENT: Right lateral (dextral) strike-slip

Comments: The sense of movement is based on analysis of tectonical-sedimentary features that are formed inside the DCARSF, geomorphological features, and the neotectonic stress field.

GEOMORPHIC EXPRESSION: In general, the DCARSF causes a reorientation of geomorphological features, with formation of $\mathrm{N} 50^{\circ} \mathrm{W}$ oriented crests along its length. It is quite visible on satellite and radar images, as well as on topographic maps (1:250,000 scale). It forms a linear divide among two large drainage basins of the state of Minas Gerais: the São Francisco and Grande rivers (tributary of the Paraná River). In detail, the DCARSF forms systems of parallel scarps, controls the geometry of alluvial plains, deflects rivers, forms grabens, and warps 
blocks. It also controls zones of accelerated erosion (voçorocas) in Resende Costa-MG and Oliveira-MG). (Note: voçorocas are big gullies, typical of humid tropical climatic conditions.)

\section{RECURRENCE INTERVAL: Unknown}

SLIP RATE: Unknown, probably $<1 \mathrm{~mm} / \mathrm{yr}$.

TIME OF MOST RECENT OF MOVEMENT: Quaternary (<1.6 Ma)

Comments: The timing is based on faulting of alluvial sediment in Pleistocene terraces. There are some geomorphological indications of movement during the Holocene. However, proving young movement is not possible without more precise dating.

NAME OF EARTHQUAKE: A great number of earthquakes have occurred along the southeast margin of the DCARSF: specially, events near Bom Sucesso-MG and Resende Costa-MG. This area has the largest concentrations of seismic events in southeast Brazil.

\section{REFERENCES}

Saadi, A., 1991, Ensaio sobre a morfotectônica de Minas Gerais-Tensões Intraplaca, Descontinuidades Crustais e Morfogênese, Belo Horizonte-MG: Universidade Federal de Minas Gerais, Instituto de Geociências, Tese para admissão a cargo de Professor Titular (inédito).

Saadi, A., 1993, Neotectônica da Plataforma Brasileira-Esboço e interpretação preliminares: Geonomos, Belo HorizonteMG, v. 1, no. 1, p. 1-15.

Saadi, A., 1993, Neotectônica e tectônica recorrente na porção sul do Cráton do São Francisco, in Simpósio Sobre o Cráton do São Francisco, 2, Salvador, 1993: Anais Sociedade Brasileira de Geologia, Salvador-BA, p. 230-232.

\section{BR-26, CAMPO DO MEIO FAULT ZONE}

FAULT NUMBER: BR-26

Comments: Shown as fault MGE-04 on initial compilation.

FAULT NAME: Campo do Meio (fault zone)

SYNOPSIS AND GEOLOGIC SETTING: This fault zone is part of the Campo do Meio shear belt that formed in the Precambrian. It is considered by most authors to be in an "unstable region from the Precambrian to the Tertiary" with evidence of reativation by normal or reverse movement. This feature was redefined by Wernick and others (1981) as the "Zona Rúptil Nova Resende-Barbacena" and mainly characterized as a left lateral strike-slip fault zone having a $\mathrm{N} 80^{\circ}-90^{\circ} \mathrm{W}$ trend during Precambrian activity. The fault zone affects rocks of the Precambrian fold belts and limits the current extent of Mesozoic sediment of the Paraná Basin in the southwestern part of the state of Minas Gerais. It is referred to as the "Alterosa Suture" by seismologists.

COMPILER AFFILIATION, AND DATE OF COMPILATION: Allaoua Saadi (Univ. Federal de Minas Gerais, Belo Horizonte, Brasil), March 1997.

TYPE OF STUDIES: Analysis of remote sensing, bibliographic compilation, and regional field data.

FAULT GEOMETRY

LENGTH: $297 \mathrm{~km}$ end to end (302 km cumulative)

END POINTS: $20^{\circ} 35^{\prime} 12^{\prime \prime}$ S., $47^{\circ} 27^{\prime} 22^{\prime \prime} \mathrm{W}$.; $21^{\circ} 54^{\prime} 27^{\prime \prime}$ S., $45^{\circ} 11^{\prime} 27^{\prime \prime} \mathrm{W}$.

AVERAGE STRIKE: $-50^{\circ}$

Comments: The fault zone's NW extent is poorly documented owing to deep soils that cover Mesozoic sedimentary rocks of the Paraná Basin.

AVERAGE DIP: Vertical

SENSE OF MOVEMENT: Strike-slip, probably left lateral (sinistral). 
GEOMORPHIC EXPRESSION: Fault zone forms alignments of crests, scarps (south border of the "Serra da Canastra"), and fluvial valleys. Offset of alluvial terraces of the area of Boa Esperança-MG are attributed to the fault zone. Has strong structural control on the orientation of the Middle Grande River valley.

\section{RECURRENCE INTERVAL: Unknown}

SLIP RATE: Unknown, probably $<1 \mathrm{~mm} / \mathrm{yr}$.

TIME OF MOST RECENT OF MOVEMENT: Quaternary (<1.6 Ma)

Comments: Timing based on faulting of alluvial sediment in Pleistocenic terraces.

\section{HISTORICAL SURFACE FAULTING: Unknown}

NAME OF EARTHQUAKE: The M 4.2 (Richter scale) earthquake of October 18, 1996, which had its epicenter in Mumbuca (Municipal District of Passos) may be related to this fault zone. The earthquake occurred at a depth of $10 \mathrm{~km}$ and it was felt over an area of $20,000 \mathrm{~km}^{2}$ having a radius of $80 \mathrm{~km}$. In the epicentral area, it would have reached intensity VI on the Mercalli scale. Since 1867, several earthquakes with upper magnitudes of 3.0 have affected sites along the fault zone.

\section{REFERENCES}

Saadi, A., 1991, Ensaio sobre a morfotectônica de Minas Gerais-Tensões Intraplaca, Descontinuidades Crustais e Morfogênese, Belo Horizonte-MG: Universidade Federal de Minas Gerais, Instituto de Geociências, Tese para admissão a cargo de Professor Titular (inédito).

Saadi, A., 1993, Neotectônica da Plataforma Brasileira-Esboço e interpretação preliminares: Geonomos, Belo HorizonteMG, v. 1, no. 1, p. 1-15.

Saadi, A., Noce, C.M., e Quintão, N.H., 1989, Neotectônica na região sul de Minas Gerais—Primeiras hipóteses, in Simpósio de Geologia de Minas Gerais, 5, Belo Horizonte-MG, 1989: Anais Sociedade Brasileira de Geologia, Belo Horizonte-MG, v. 10, p. 115-119.

\section{BR-27, CARATINGA FAULT}

FAULT NUMBER: BR-27

Comments: Shown as fault MGE-05 on initial compilation.

FAULT NAME: Caratinga (fault)

SYNOPSIS AND GEOLOGIC SETTING: The Caratinga fault is part of a shear zone that is formed by thrust faults of the Neoproterozoic fold belt of Southeast Brazil. This shear zone is considered, on the basis of geophysical data, as a first-order deep crustal discontinuity named the " Abre Campo lineament" (or suture). It is located in the southeastern part of the state of Minas Gerais, where it affects rocks that are primarily Archean. However, they were reactivated during the Brasilian Orogenesis (Neoproterozoic).

COMPILER AFFILIATION, AND DATE OF COMPILATION: Allaoua Saadi (Univ. Federal de Minas Gerais, Belo Horizonte, Brasil), March 1997.

TYPE OF STUDIES: Analysis of documents of remote sensing, bibliographical compilation and regional field data.

\section{FAULT GEOMETRY}

LENGTH: $311 \mathrm{~km}$ end to end ( $318 \mathrm{~km}$ cumulative)

END POINTS: $19^{\circ} 19^{\prime} 00^{\prime \prime}$ S., $41^{\circ} 47^{\prime} 35^{\prime \prime} \mathrm{W} . ; 21^{\circ} 44^{\prime} 2^{\prime \prime}$ S., $42^{\circ} 54^{\prime} 31^{\prime \prime} \mathrm{W}$.

AVERAGE STRIKE: $24^{\circ}$

Comments: Fault has slightly sinuous trace, inherited from Neoproterozoic thrust faults.

AVERAGE DIP: $70^{\circ}$ to east, at surface.

SENSE OF MOVEMENT: Probably strike-slip with vertical component.

Comments: Sense of lateral slip is unknown. 
GEOMORPHIC EXPRESSION: Scarps and crests of great relief along the "Serra da Mantiqueira" and strong linear, structural control of fluvial valleys (Caratinga River, Upper Muriae River, etc.).

RECURRENCE INTERVAL: Unknown

SLIP RATE: Unknown, probably $<1 \mathrm{~mm} / \mathrm{yr}$.

TIME OF MOST RECENT OF MOVEMENT: Quaternary (<1.6 Ma)

Comments: Timing based on faulting of alluvial and colluvial deposits of Pleistocene age (relative dating) in the basin of the Doce River.

\section{REFERENCES}

Saadi, A., 1991, Ensaio sobre a morfotectônica de Minas Gerais-Tensões Intraplaca, Descontinuidades Crustais e Morfogênese, Belo Horizonte-MG: Universidade Federal de Minas Gerais, Instituto de Geociências, Tese para admissão a cargo de Professor Titular (inédito).

Saadi, A., 1993, Neotectônica da Plataforma Brasileira-Esboço e interpretação preliminares: Geonomos, Belo HorizonteMG, v. 1, no. 1, p. 1-15.

Souza, C.J. de O., e Saadi, A., 1994, Contribuição à geomorfologia da bacia do Rio Doce, in Simpósio Nacional de Geografia Física Aplicada, 4, São Paulo-SP: Anais Universidade de São Paulo, São Paulo-SP, p.157-161.

\section{BR-28, ESTRELA FAULT}

FAULT NUMBER: BR-28

Comments: Shown as fault MGE-06 on initial compilation.

FAULT NAME: Estrela (fault)

SYNOPSIS AND GEOLOGIC SETTING: The Estrela fault was a thrust during the Brasiliano Orogenesis

(Neoproterozoic) and now is forms the contact structure between the Brasília fold belt and the western border of the São Francisco Craton (CSF). It affects Archean basement rocks and its Neoproterozoic metasedimentary cover, and limits the eastward extension of the "Bacia Sanfranciscana" (Cretaceous sedimentary basin). It is located in the west central part of the state of Minas Gerais (MG).

COMPILER AFFILIATION, AND DATE OF COMPILATION: Allaoua Saadi (Univ. Federal de Minas Gerais, Belo Horizonte, Brasil), March 1997.

TYPE OF STUDIES: Morpho-neotectonic studies based on cartographic documents, remote sensing, and field data.

\section{FAULT GEOMETRY}

LENGTH: $226 \mathrm{~km}$ end to end ( $228 \mathrm{~km}$ cumulative)

END POINTS: $18^{\circ} 7^{\prime} 27^{\prime \prime}$ S., $45^{\circ} 0^{\prime} 49^{\prime \prime}$ W.; $19^{\circ} 51^{\prime} 35^{\prime \prime}$ S., $45^{\circ} 54^{\prime} 20^{\prime \prime} \mathrm{W}$.

AVERAGE STRIKE: $26^{\circ}$

Comments: The Estrela fault is a "scissors fault", having maximum throw to the south (south margin of the "Serra da Saudade") and a scarp about $300 \mathrm{~m}$ high. However, there is perhaps no throw to the north, next to the Três Marias lake (a reservoir). Based on geophysical data (Haralyi and others, 1985), it appears to limi a postCretaceous uplifted structure named "Soerguimento do Alto Paranaíba."

AVERAGE DIP: Probably $70^{\circ} \mathrm{W}$ in subsurface.

SENSE OF MOVEMENT: Probably reverse with strike-slip component

Comments: Reverse component is west over east.

GEOMORPHIC EXPRESSION: Fault-line scarp with great expression and control of long section of the São Francisco River.

RECURRENCE INTERVAL: Unknown

SLIP RATE: Unknown, probably $<1 \mathrm{~mm} / \mathrm{yr}$. 
TIME OF MOST RECENT OF MOVEMENT: Quaternary (<1.6 Ma)

Comments: Interpretation based on geomorphological data.

\section{REFERENCES}

Haralyi, N.L.E., Hasui, Y.; Mioto, J.A., Hamza, V.M., e Rodrigues, C.R.V., 1985, Ensaio sobre a estruturação crustal do Estado de Minas Gerais, com base na informação geofísica e geológica, in Contribution to the geology and the petrology: Sociedade Brasileira de Geologia Special Publication, Belo Horizonte-MG,1985, p. 71-93.

Saadi, A., 1991, Ensaio sobre a morfotectônica de Minas Gerais-Tensões Intraplaca, Descontinuidades Crustais e Morfogênese, Belo Horizonte-MG: Universidade Federal de Minas Gerais, Instituto de Geociências, Tese para admissão a cargo de Professor Titular (inédito).

Saadi, A., 1993, Neotectônica da Plataforma Brasileira—Esboço e interpretação preliminares: Geonomos, Belo HorizonteMG, v. 1, no. 1, p. 1-15.

Saadi, A., 1993, Neotectônica e tectônica recorrente na porção sul do Cráton do São Francisco, in Simpósio Sobre o Cráton do São Francisco, 2, Salvador, 1993: Anais Sociedade Brasileira de Geologia, Salvador-BA, p. 230-232.

\section{BR-29, CARDEAL MOTA FAULT}

FAULT NUMBER: BR-29

Comments: Shown as fault MGE-07 on initial compilation.

FAULT NAME: Cardeal Mota (fault)

SYNOPSIS AND GEOLOGIC SETTING: The Cardeal Mota fault was a thrust during the Brasiliano Orogenesis (Neoproterozoic), and now forms the contact structure between the Araçuai fold belt and the southeastern border of the São Francisco Craton (CSF). The fault affects Archean basement and its Neoproterozoic metasedimentary rock cover. This fault marks the western limit of the "Serra do Espinhaço Meridional," which corresponds to the front of the Brasiliano thrust fault.

COMPILER AFFILIATION, AND DATE OF COMPILATION: Allaoua Saadi (Univ. Federal de Minas Gerais, Belo Horizonte, Brasil), March 1997.

TYPE OF STUDIES: Morpho-neotectonic studies of cartographic and remote sensing documents, and field data.

\section{FAULT GEOMETRY}

LENGTH: $98 \mathrm{~km}$ end to end (98 km cumulative)

END POINTS: $18^{\circ} 32^{\prime} 51^{\prime \prime}$ S., $43^{\circ} 38^{\prime} 25^{\prime \prime} \mathrm{W} . ; 19^{\circ} 17^{\prime} 45^{\prime \prime}$ S., $43^{\circ} 14^{\prime} 11^{\prime \prime} \mathrm{W}$.

AVERAGE STRIKE: $-27^{\circ}$

AVERAGE DIP: Probably around $60^{\circ} \mathrm{E}$ at surface

SENSE OF MOVEMENT: Probably reverse

Comments: Reverse component is east over west thrusting. Interpretation based on the geomorphological

information and observations of conspicuous deformation of Quaternary alluvial deposits.

GEOMORPHIC EXPRESSION: Fault-line scarp, which reaches a maxmium height of $300 \mathrm{~m}$, corresponds to the front of the Brasiliano thrust fault.

RECURRENCE INTERVAL: Unknown

SLIP RATE: Unknown, probably $<1 \mathrm{~mm} / \mathrm{yr}$.

TIME OF MOST RECENT OF MOVEMENT: Quaternary (<1.6 Ma)

Comments: Interpretation based on geomorphological data.

\section{REFERENCES}


Saadi, A., 1991, Ensaio sobre a morfotectônica de Minas Gerais-Tensões Intraplaca, Descontinuidades Crustais e Morfogênese, Belo Horizonte-MG: Universidade Federal de Minas Gerais, Instituto de Geociências, Tese para admissão a cargo de Professor Titular (inédito).

Saadi, A., 1993, Neotectônica da Plataforma Brasileira-Esboço e interpretação preliminares: Geonomos, Belo HorizonteMG, v. 1, no. 1, p. 1-15.

Saadi, A., 1993, Neotectônica e tectônica recorrente na porção sul do Cráton do São Francisco, in Simpósio Sobre o Cráton do São Francisco, 2, Salvador, 1993: Anais Sociedade Brasileira de Geologia, Salvador-BA, p. 230-232.

Saadi, A., 1995, Geomorfologia da Serra do Espinhaço em Minas Gerais e de suas margens: Geonomos, Belo Horizonte-MG, v. 3, no. 1, p. 41-63.

\section{BR-30, LOWER XINGU FAULT}

FAULT NUMBER: BR-30

Comments: Shown as fault PAR-01 on initial compilation.

FAULT NAME: Lower Xingu (fault)

SYNOPSIS AND GEOLOGIC SETTING: The Lower Xingu fault is located in the Lower Amazonas River region (state of Pará). It affects Paleozoic and Mesozoic sedimentary rock of the Intracratonic Amazon Basin.

COMPILER AFFILIATION, AND DATE OF COMPILATION: Allaoua Saadi (Univ. Federal de Minas Gerais, Belo Horizonte, Brasil), March 1997.

TYPE OF STUDIES: Compilation of cartographic and bibliographic data.

FAULT GEOMETRY

LENGTH: $466 \mathrm{~km}$ end to end (467 km cumulative)

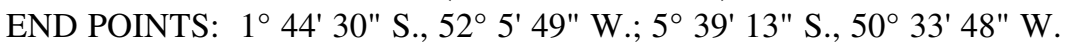

AVERAGE STRIKE: $-22^{\circ}$

AVERAGE DIP: Subvertical

SENSE OF MOVEMENT: Probably normal, west side down

GEOMORPHIC EXPRESSION: Fault has strong structural control of the valley of Lower Xingu River where it forms an abrupt change in trend from ENE-WSW to N-S.

RECURRENCE INTERVAL: Unknown

SLIP RATE: Unknown, probably $<1 \mathrm{~mm} / \mathrm{yr}$.

TIME OF MOST RECENT OF MOVEMENT: Quaternary $(<1.6 \mathrm{Ma})$

\section{REFERENCES}

Assumpção, M., Suarez, G., and Veloso, J.A., 1985, Fault plane solutions of intraplate earthquakes in Brazil—Some constraints on the regional stress field: Tectonophysics, v. 113, p. 283-293.

Bemerguy, R.L., e Sena Costa, J.B., 1991, Considerações sobre a evolução do sistema de drenagem da Amazônia e sua relação com o arcabouço tectônico-estrutural: Boletim do Museu Paraense Emílio Goeldi, Série Ciências da Terra, v. 3, p. 76-97.

Costa, J.B.S., Hasui, H., Borges, M. da S., Bemerguy, R.L., Saadi, A., e Costa Jr, R.S., 1994, Arcabouço tectônico MesoCenozóico da região da calha do Amazonas, in Simpósio de Geologia da Amazônia, 4, Belém, 1994: Anais Sociedade Brasileira de Geologia, Belém-NO, v. 1, p. 47-50.

Iriondo, M.H., and Suguio, K., 1981, Neotectonics of the Amazon Plain: Bulletin of INQUA, Neotectonic Commission, v. 4, p. $72-78$.

Lima, M.I.C., 1988, Lineamentos estruturais na sequiência cenozóica Solimões e suas relações com o Cráton Amazônico e Bacia do Alto Amazonas, in Congresso Brasileiro de Geologia, 35, Belém, 1988: Anais Sociedade Brasileira de Geologia, Belém-NO, v. 6, p. 2396-2402. 
Sternberg, H.O., 1950, Vales tectônicos na planície amazônica: Revista Brasileira de Geografia, Rio de Janeiro, v. 12, no. 4, p. 3-26.

Sternberg, H.O., 1953, Sismicidade e morfologia na Amazônia Brasileira: Anais da Academia Brasileira de Ciências, v. 25, no. 4 , p. 443-453.

\section{BR-31, MACAPÁ FAULT}

FAULT NUMBER: BR-31

Comments: Shown as fault PAR-02 on initial compilation.

FAULT NAME: Macapá (fault)

SYNOPSIS AND GEOLOGIC SETTING: The Macapá fault is located in the outlet of the Amazonas River, along the northen channel, between the states of Amapá and Pará. It is at the eastern margin of the Intracratonic Amazon Basin. The fault forms the northern border of Marajó Bay, which has subsidenced during the Cenozoic and perhaps is still ongoing.

COMPILER AFFILIATION, AND DATE OF COMPILATION: Allaoua Saadi (Univ. Federal de Minas Gerais, Belo Horizonte, Brasil), March 1997.

TYPE OF STUDIES: Compilation of cartographic and bibliographic data, and field observation (1992).

\section{FAULT GEOMETRY}

LENGTH: $367 \mathrm{~km}$ end to end ( $368 \mathrm{~km}$ cumulative)

END POINTS: $1^{\circ} 11^{\prime} 21^{\prime \prime}$ N., $49^{\circ} 12^{\prime} 29^{\prime \prime} \mathrm{W} . ; 1^{\circ} 16^{\prime} 26^{\prime \prime} \mathrm{S} ., 51^{\circ} 24^{\prime} 55^{\prime \prime} \mathrm{W}$.

AVERAGE STRIKE: $42^{\circ}$

AVERAGE DIP: Probably subvertical

SENSE OF MOVEMENT: Probably right lateral (dextral) strike-slip with normal component.

GEOMORPHIC EXPRESSION: Strong structural control of the southeastern coastline of the state of Amapá, of the northern channel (branch of the outlet) of Amazonas River, and alignment of the northwest Pará Islands.

\section{RECURRENCE INTERVAL: Unknown}

SLIP RATE: Unknown, probably $<1 \mathrm{~mm} / \mathrm{yr}$.

TIME OF MOST RECENT OF MOVEMENT: Holocene and post glacial ( $<15 \mathrm{ka})$

Comments: Holocene muds deposited by the Amazonas River are involved in deformation and subsidence related to the Macapá fault.

\section{REFERENCES}

Assumpção, M., Suarez, G., and Veloso, J.A., 1985, Fault plane solutions of intraplate earthquakes in Brazil—Some constraints on the regional stress field: Tectonophysics, v. 113, p. 283-293.

Bemerguy, R.L., e Sena Costa, J.B., 1991, Considerações sobre a evolução do sistema de drenagem da Amazônia e sua relação com o arcabouço tectônico-estrutural: Boletim do Museu Paraense Emílio Goeldi, Série Ciências da Terra, v. 3, p. 76-97.

Costa, J.B.S., Hasui, H., Borges, M. da S., Bemerguy, R.L., Saadi, A., e Costa Jr, R.S., 1994, Arcabouço tectônico MesoCenozóico da região da calha do Amazonas, in Simpósio de Geologia da Amazônia, 4, Belém, 1994: Anais Sociedade Brasileira de Geologia, Belém-NO, v. 1, p. 47-50.

Cunha, F.M.B. da, 1991, Morfologia e neotectonismo do Rio Amazonas, in Simpósio de Geologia da Amazônia, 3, Belém, 1991: Anais Sociedade Brasileira de Geologia/Núcleo Norte, Belém-PA, p. 193-210.

Igreja, H.L.S., Borges, M.S., Alves, R.J., Costa Jr., P.S., e Sena Costa, J.B., 1990, Estudos neotectônicas nas ilhas de Outeiro e Mosqueiro, nordeste do Estado do Pará, in Congresso Brasileiro de Geologia, 36, Natal, 1990: Anais Sociedade Brasileira de Geologia, Natal-RN, v. 5, p. 2110-2123. 
Iriondo, M.H., and Suguio, K., 1981, Neotectonics of the Amazon Plain: Bulletin of INQUA, Neotectonic Commission, v. 4, p. $72-78$.

Sena Costa, J.B., Borges, M.S., Bemerguy, R.L., Igreja, H.L.S., e Pinheiro, R.V.L.,1991, Aspectos da tectônica cenozóica na região do Salgado, litoral nordeste do Estado do Pará, in Simpãsio de Geologia da AmazÈnia, 3, Belém, 1991: Anais Sociedade Brasileira de Geologia/Núcleo Norte, Belém-PA, p.156-165.

Sternberg, H.O., 1950, Vales tectônicos na planície Amazônica: Revista Brasileira de Geografia, Rio de Janeiro, v. 12, no. 4, p. 3-26.

Sternberg, H.O., 1953, Sismicidade e morfologia na Amazônia Brasileira: Anais da Academia Brasileira de Ciências, v. 25, no. 4 , p. 443-453.

\section{BR-32, MONTE ALEGRE FAULT}

FAULT NUMBER: BR-32

Comments: Shown as fault PAR-03 on initial compilation.

FAULT NAME: Monte Alegre

SYNOPSIS AND GEOLOGIC SETTING: The Monte Alegre fault is located in the central part of the Lower Amazonas River basin, in the State of Pará. It is along the axis of the Intracratonic Amazonas Basin (PaleozoicMesozoic) and affects Cretaceous-Tertiary sandstones of the Alter do Chão Formation. May limit northern extent of Cardeal Mota fault (BR-30) and Lower Tapajós fault (BR-34).

COMPILER AFFILIATION, AND DATE OF COMPILATION: Allaoua Saadi (Univ. Federal de Minas Gerais, Belo Horizonte, Brasil), March 1997.

TYPE OF STUDIES: Compilation of cartographic and bibliographic data, and field observations (Allaoua Saadi, 1992).

FAULT GEOMETRY

LENGTH: $330 \mathrm{~km}$ end to end ( $330 \mathrm{~km}$ cumulative)

END POINTS: $1^{\circ} 26^{\prime} 26^{\prime \prime}$ S., $51^{\circ} 36^{\prime} 33^{\prime \prime} \mathrm{W}$.; $2^{\circ} 22^{\prime} 16^{\prime \prime}$ S., $54^{\circ} 25^{\prime} 46^{\prime \prime} \mathrm{W}$.

AVERAGE STRIKE: $72^{\circ}$

AVERAGE DIP: Probably subvertical

SENSE OF MOVEMENT: Probably right lateral (dextral) strike-slip with normal component.

GEOMORPHIC EXPRESSION: Strong structural control of the middle part of the western section of the Amazon River.

\section{RECURRENCE INTERVAL: Unknown}

SLIP RATE: Unknown, probably $<1 \mathrm{~mm} / \mathrm{yr}$.

TIME OF MOST RECENT OF MOVEMENT: Quaternary (<1.6 Ma)

\section{REFERENCES}

Assumpção, M., Suarez, G., and Veloso, J.A., 1985, Fault plane solutions of intraplate earthquakes in Brazil—Some constraints on the regional stress field: Tectonophysics, v. 113, p. 283-293.

Bemerguy, R.L., e Sena Costa, J.B., 1991, Considerações sobre a evolução do sistema de drenagem da Amazônia e sua relação com o arcabouço tectônico-estrutural: Boletim do Museu Paraense Emílio Goeldi, Série Ciências da Terra, v. 3, p. 76-97.

Costa, J.B.S., Hasui, H., Borges, M. da S., Bemerguy, R.L., Saadi, A., e Costa Jr, R.S., 1994, Arcabouço tectônico MesoCenozóico da região da calha do Amazonas, in Simpósio de Geologia da Amazônia, 4, Belém, 1994: Anais Sociedade Brasileira de Geologia, Belém-NO, v. 1, p. 47-50.

Cunha, F.M.B. da, 1991, Morfologia e neotectonismo do Rio Amazonas, in Simpósio de Geologia da Amazônia, 3, Belém, 1991: Anais Sociedade Brasileira de Geologia/Núcleo Norte, Belém-PA, p. 193-210. 
Iriondo, M.H., and Suguio, K., 1981, Neotectonics of the Amazon Plain: Bulletin of INQUA, Neotectonic Commission, v. 4, p. $72-78$.

Sternberg, H.O., 1950, Vales tectônicos na planície amazônica: Revista Brasileira de Geografia, Rio de Janeiro, v. 12 , no. 4, p. 3-26.

Sternberg, H.O., 1953, Sismicidade e morfologia na Amazônia Brasileira: Anais da Academia Brasileira de Ciências, v. 25, no. 4 , p. 443-453.

Travassos, W.A.S., e Barbosa Filho, C.M., 1990, Tectonismo Terciário na área do Rio Tapajós, Bacia do Rio Amazonas: Boletim de Geociências da PETROBRÁS, v. 4, no. 3, p. 221-340.

\section{BR-33, LOWER TROMBETAS FAULT}

FAULT NUMBER: BR-33

Comments: Shown as fault PAR-04 on initial compilation.

FAULT NAME: Lower Trombetas (fault)

SYNOPSIS AND GEOLOGIC SETTING: The Lower Trombetas fault is located in the lower basin of the Trombetas River and at its confluence with the Amazonas River, in the west part of the state of Pará. The fault is in Paleozoic and Mesozoic sedimentary rocks at the north side of the Intracratonic Amazonas Basin.

COMPILER AFFILIATION, AND DATE OF COMPILATION: Allaoua Saadi (Univ. Federal de Minas Gerais, Belo Horizonte, Brasil), March 1997.

TYPE OF STUDIES: Compilation of cartographic and bibliographic data, and field observations (Allaoua Saadi, 1992).

\section{FAULT GEOMETRY}

LENGTH: $253 \mathrm{~km}$ end to end ( $253 \mathrm{~km}$ cumulative)

END POINTS: $1^{\circ} 13^{\prime} 49^{\prime \prime}$ S., $56^{\circ} 54^{\prime} 38^{\prime \prime}$ W.; $2^{\circ} 14^{\prime} 31^{\prime \prime}$ S., $54^{\circ} 52^{\prime} 19^{\prime \prime} \mathrm{W}$.

AVERAGE STRIKE: $-64^{\circ}$

AVERAGE DIP: Unknown angle to the southwest?

SENSE OF MOVEMENT: Normal.

GEOMORPHIC EXPRESSION: Fault exhibits strong structural control onthe lower section of the Trombetas River and the section of Amazon River defined by the Oriximiná-Óbidos-Santarém axis.

\section{RECURRENCE INTERVAL: Unknown}

SLIP RATE: Unknown, probably $<1 \mathrm{~mm} / \mathrm{yr}$.

\section{TIME OF MOST RECENT OF MOVEMENT: Quaternary (<1.6 Ma)}

\section{REFERENCES}

Assumpção, M., Suarez, G., and Veloso, J.A., 1985, Fault plane solutions of intraplate earthquakes in Brazil—Some constraints on the regional stress field: Tectonophysics, v. 113, p. 283-293.

Bemerguy, R.L., e Sena Costa, J.B., 1991, Considerações sobre a evolução do sistema de drenagem da Amazônia e sua relação com o arcabouço tectônico-estrutural: Boletim do Museu Paraense Emílio Goeldi, Série Ciências da Terra, v. 3, p. 76-97.

Costa, J.B.S., Hasui, H., Borges, M. da S., Bemerguy, R.L., Saadi, A., e Costa Jr, R.S., 1994, Arcabouço tectônico MesoCenozóico da região da calha do Amazonas, in Simpósio de Geologia da Amazônia, 4, Belém, 1994: Anais Sociedade Brasileira de Geologia, Belém-NO, v. 1, p. 47-50.

Cunha, F.M.B. da, 1991, Morfologia e neotectonismo do Rio Amazonas, in Simpósio de Geologia da Amazônia, 3, Belém, 1991: Anais Sociedade Brasileira de Geologia/Núcleo Norte, Belém-PA, p. 193-210. 
Franzinelli, E., e Piuci, J., 1988, Evidências de neotectonismo na Bacia Amazônica, in Congresso Latino-Americano de Geologia, 7, Belém, 1988: Anais Sociedade Brasileira de Geologia/Núcleo Norte, Belém-PA, p. 80-90.

Iriondo, M.H., and Suguio, K., 1981, Neotectonics of the Amazon Plain: Bulletin of INQUA, Neotectonic Commission, v. 4, p. $72-78$.

Sternberg, H.O., 1950, Vales tectônicos na planície amazônica: Revista Brasileira de Geografia, Rio de Janeiro, v. 12, no. 4, p. 3-26.

Sternberg, H.O., 1953, Sismicidade e morfologia na Amazônia Brasileira: Anais da Academia Brasileira de Ciências, v. 25, no. 4, p. 443-453.

Travassos, W.A.S., e Barbosa Filho, C.M., 1990, Tectonismo Terciário na área do Rio Tapajós, Bacia do Rio Amazonas: Boletim de Geociências da PETROBRÁS, v. 4, no. 3, p. 221-340.

\section{BR-34, LOWER TAPAJÓS FAULT}

FAULT NUMBER: BR-34

Comments: Shown as fault PAR-05 on initial compilation.

FAULT NAME: Lower Tapajós

SYNOPSIS AND GEOLOGIC SETTING: The Lower Tapajós fault is located along the lower basin of the Tapajós River and at its confluence with the Amazonas River, in the western part of the state of Pará. The fault is in Paleozoic and Mesozoic sedimentary rock on the south side of the Intracratonic Amazon Basin.

COMPILER AFFILIATION, AND DATE OF COMPILATION: Allaoua Saadi (Univ. Federal de Minas Gerais, Belo Horizonte, Brasil), March 1997.

TYPE OF STUDIES: Compilation of cartographic and bibliographic data, and field observations (Allaoua Saadi, 1992).

FAULT GEOMETRY

LENGTH: $184 \mathrm{~km}$ end to end (184 km cumulative)

END POINTS: $2^{\circ} 13^{\prime} 22^{\prime \prime}$ S., 54 $37^{\prime} 31^{\prime \prime}$ W.; $3^{\circ} 46^{\prime} 3^{\prime \prime}$ S., $55^{\circ} 14^{\prime} 24^{\prime \prime} \mathrm{W}$.

AVERAGE STRIKE: $22^{\circ}$

AVERAGE DIP: Probably subvertical at surface

SENSE OF MOVEMENT: Normal, down to southeast

GEOMORPHIC EXPRESSION: Fault has linear control of the lake formed on the Lower Tapajós River.

RECURRENCE INTERVAL: Unknown

SLIP RATE: Unknown, probably $<1 \mathrm{~mm} / \mathrm{yr}$.

TIME OF MOST RECENT OF MOVEMENT: Quaternary (<1.6 Ma)

\section{REFERENCES}

Assumpção, M., Suarez, G., and Veloso, J.A., 1985, Fault plane solutions of intraplate earthquakes in Brazil—Some constraints on the regional stress field: Tectonophysics, v. 113, p. 283-293.

Bemerguy, R.L., e Sena Costa, J.B., 1991, Considerações sobre a evolução do sistema de drenagem da Amazônia e sua relação com o arcabouço tectônico-estrutural: Boletim do Museu Paraense Emílio Goeldi, Série Ciências da Terra, v. 3, p. 76-97.

Costa, J.B.S., Hasui, H., Borges, M. da S., Bemerguy, R.L., Saadi, A., e Costa Jr, R.S., 1994, Arcabouço tectônico MesoCenozóico da região da calha do Amazonas, in Simpósio de Geologia da Amazônia, 4, Belém, 1994: Anais Sociedade Brasileira de Geologia, Belém-NO, v. 1, p. 47-50.

Cunha, F.M.B. da, 1991, Morfologia e neotectonismo do Rio Amazonas, in Simpósio de Geologia da Amazônia, 3, Belém, 1991: Anais Sociedade Brasileira de Geologia/Núcleo Norte, Belém-PA, p. 193-210. 
Iriondo, M.H., and Suguio, K., 1981, Neotectonics of the Amazon Plain: Bulletin of INQUA, Neotectonic Commission, v. 4, p. $72-78$.

Sternberg, H.O., 1950, Vales tectônicos na planície amazônica: Revista Brasileira de Geografia, Rio de Janeiro, v. 12 , no. 4, p. 3-26.

Sternberg, H.O., 1953, Sismicidade e morfologia na Amazônia Brasileira: Anais da Academia Brasileira de Ciências, v. 25, no. 4 , p. 443-453.

Travassos, W.A.S., e Barbosa Filho, C.M., 1990, Tectonismo Terciário na área do Rio Tapajós, Bacia do Rio Amazonas: Boletim de Geociências da PETROBRÁS, v. 4, no. 3, p. 221-340.

\section{BR-35, PATOS LINEAMENT}

FAULT NUMBER: BR-35

Comments: Shown as fault PBA-10 on initial compilation.

FAULT NAME: Patos (lineament)

SYNOPSIS AND GEOLOGIC SETTING: The Patos lineament is a shear zone formed during the Precambrian. It affects igneous and metamorphic rocks that were deformed during the tectonic-metamorphic Brasiliano event (Neoproterozoic). It is composed of several faults and shear zones, which have predominantly right lateral strikeslip, that form anostomosed network of sinuous traces in a general E-W direction. It controlled the formation and evolution of Mesozoic sedimentary basins, specially along the northern boundary of the Araripe Basin. It constitutes the continental extension of an oceanic fracture zone that is named the "Paraíba lineament."

COMPILER AFFILIATION, AND DATE OF COMPILATION: Allaoua Saadi (Univ. Federal de Minas Gerais, Belo Horizonte, Brasil), March 1997.

TYPE OF STUDIES: Compilation of cartographic and bibliographic data, as well as regional field data.

FAULT GEOMETRY

LENGTH: $461 \mathrm{~km}$ end to end (461 km cumulative)

LENGTH (DETERMINED FROM GIS): $7^{\circ} 39^{\prime}$ 49" S., 39 18' 38" W.; $7^{\circ} 49^{\prime} 35^{\prime \prime}$ S., $35^{\circ} 6^{\prime} 12^{\prime \prime} \mathrm{W}$.

AVERAGE STRIKE: $-87^{\circ}$

Comments: Average direction of the zone of anastomosing faults.

AVERAGE DIP: Unknown

SENSE OF MOVEMENT: Probably right lateral (dextral) strike-slip.

Comments: The sense of movement was determined from neotectonic stress fields in the northern part of the Northeast Region of Brazil.

GEOMORPHIC EXPRESSION: Fault forms a sequence of fault-line scarps, crests and depressions visible on satellite and radar images. It establishes the southern limit of the great Sertaneja depression, marking the regional water divide.

\section{RECURRENCE INTERVAL: Unknown}

SLIP RATE: Unknown, probably $<1 \mathrm{~mm} / \mathrm{yr}$.

TIME OF MOST RECENT OF MOVEMENT: Quaternary (<1.6 Ma)

Comments: Timing from the geomorphological indicators and relative dating of geomorphological features.

\section{REFERENCES}

Beurlen, K., 1967, A estrutura geológica do Nordeste do Brasil, in Congresso Brasileiro de Geologia, 21, Curitiba, 1967: Anais Sociedade Brasileira de Geologia, Curitiba-PR, 1967, p. 151-158.

Corsini, M., 1995, Geométrie, cinématique e signification tectonique des systèmes de décrochements ductiles intracontinentaux de la Province Borborema (NE Brésil): Geodinamica Acta, Paris, v. 8, no. 3, p. 129-141. 
Kegel, W., 1961, Os lineamentos na estrutura geológica do Nordeste: Anais da Academia Brasileira de Ciências, Rio de Janeiro, v. 33, p. 1-25.

Saadi, A., 1993, Neotectônica da Plataforma Brasileira-Esboço e interpretação preliminares: Geonomos, Belo HorizonteMG, v. 1, no. 1, p. 1-15.

\section{BR-36, PERNAMBUCO LINEAMENT}

FAULT NUMBER: BR-36

Comments: Shown as fault PER-01 on initial compilation.

FAULT NAME: Pernambuco (lineament)

SYNOPSIS AND GEOLOGIC SETTING: The Pernambuco lineament is a shear zone that was formed during the Precambrian. It affects igneous and metamorphic rocks that were deformed during the Brasiliano Orogenesis (Neoproterozoic). It is composed of several faults, predominantly right lateral strike-slip, forming an anastomosed net and sinuous traces, predominant in an E-W direction It constitutes the continental continuation of an oceanic fracture zone that is also called the "Pernambuco lineament."

COMPILER AFFILIATION, AND DATE OF COMPILATION: Allaoua Saadi (Univ. Federal de Minas Gerais, Belo Horizonte, Brasil), March 1997.

TYPE OF STUDIES: Compilation of cartographic and bibliographic data, as well as general field control.

\section{FAULT GEOMETRY}

LENGTH: $716 \mathrm{~km}$ end to end (723 km cumulative)

END POINTS: $8^{\circ} 6^{\prime} 58^{\prime \prime}$ S., $41^{\circ} 14^{\prime} 31^{\prime \prime}$ W.; $8^{\circ} 36^{\prime} 17^{\prime \prime}$ S., 34 $49^{\prime} 48^{\prime \prime} \mathrm{W}$.

AVERAGE STRIKE: $-86^{\circ}$

AVERAGE DIP: Unknown

SENSE OF MOVEMENT: Probably right lateral (dextral) strike-slip

Comments: The sense of movement is determined from the neotectonic stress field in the northern part of the Northeast Region of Brazil.

GEOMORPHIC EXPRESSION: Fault forms sequences of fault-line scarps, crests and depressions, as well as the water divide between the São Francisco River basin and the fluvial basins of Northeast Brazil.

\section{RECURRENCE INTERVAL: Unknown}

SLIP RATE: Unknown, probably $<1 \mathrm{~mm} / \mathrm{yr}$.

TIME OF MOST RECENT OF MOVEMENT: Quaternary (<1.6 Ma)

Comments: The timing is based on geomorphological indicators and relative dating of geomorphological features.

\section{REFERENCES}

Beurlen, K., 1967, A estrutura geológica do Nordeste do Brasil, in Congresso Brasileiro de Geologia, 21, Curitiba, 1967: Anais Sociedade Brasileira de Geologia, Curitiba-PR, 1967, p. 151-158.

Corsini, M., 1995, Geométrie, cinématique e signification tectonique des systèmes de décrochements ductiles intracontinentaux de la Province Borborema (NE Brésil): Geodinamica Acta, Paris, v. 8, no. 3, p. 129-141.

Davison, I., McCarthy, M., Powel, D., Torres, H.F.F., and Santos, C.A., 1995, Laminar flow in shear zone-The Pernambuco Shear Zone, NE Brazil: Journal of Structural Geology, v. 17, p. 149-161.

Kegel, W., 1961, Os lineamentos na estrutura geológica do Nordeste: Anais da Academia Brasileira de Ciências, Rio de Janeiro, v. 33, p. 1-25.

Saadi, A., 1993, Neotectônica da Plataforma Brasileira-Esboço e interpretação preliminares: Geonomos, Belo HorizonteMG, v. 1, no. 1, p. 1-15. 


\section{BR-37, AFONSO BEZERRA FAULT}

FAULT NUMBER: BR-37

Comments: Shown as fault RGN-01 on initial compilation.

FAULT NAME: Afonso Bezerra (fault)

SYNOPSIS AND GEOLOGIC SETTING: The Afonso Bezerra fault is located within the Potiguar Basin (state of Rio Grande do Norte). It is a sedimentary basin that was formed during the Mesozoic fragmentation of Gondwana. Southern limit of fault is the Lajes lineament (BR-40).

COMPILER AFFILIATION, AND DATE OF COMPILATION: Vanildo Pereira da Fonseca (Univ. Federal do Rio Grande do Norte) and Allaoua Saadi (Univ. Federal de Minas Gerais, Belo Horizonte, Brasil), March 1997.

TYPE OF STUDIES: Geological and geomorphological studies based on interpretation of aerial photos and Landsat images, and field data.

FAULT GEOMETRY

LENGTH: $118 \mathrm{~km}$ end to end (118 km cumulative)

END POINTS: $4^{\circ} 59^{\prime} 38^{\prime \prime}$ S., $36^{\circ} 46^{\prime} 28^{\prime \prime}$ W.; $5^{\circ} 41^{\prime} 37^{\prime \prime}$ S., $35^{\circ} 58^{\prime} 46^{\prime \prime} \mathrm{W}$.

AVERAGE STRIKE: $-49^{\circ}$

SENSE OF MOVEMENT: Left lateral (sinistral) strike-slip

Comments: Reported as right lateral strike-slip during Oligocene to Miocene time (Fonseca, 1996, 1997).

However, if you take into account the current stress field based on focal mechanisms (Ferriera and others, 1987, 1995, 1998) and borehole breakouts (Lima and others, 1997), which points to an E-W trending horizontal maximum stress direction, the sense of Quaternary fault movement must be left lateral.

GEOMORPHIC EXPRESSION: Fault exerts linear control on rivers, deflection of fluvial channels, and controls the geometry of the Holocene coastline.

\section{RECURRENCE INTERVAL: Unknown}

\section{SLIP RATE: Unknown}

TIME OF MOST RECENT OF MOVEMENT: Holocene and post glacial ( $<15 \mathrm{ka})$

Comments: The fault affects beach rock with a $\mathrm{C}^{14}$ age determination of 5,120 years B.P. (Silva, 1992).

\section{REFERENCES}

Assumpção, M., Suarez, G., and Veloso, J.A., 1985, Fault plane solutions of intraplate earthquakes in Brazil—Some constraints on the regional stress field: Tectonophysics, v. 113, p. 283-293.

Berrocal, J., Barros, J., e Oliveira, R., 1971, Sismotectônica do Nordeste Brasileiro, in Congresso Brasileiro de Geologia, 25, São Paulo, 1971: Anais Sociedade Brasileira de Geologia, São Paulo-SP, v. 2, p. 129-137.

Carneiro, C.D.R., Hamza, V.M., e Almeida, F.F.M. de, 1989, Ativação tectônica, fluxo geotérmico e sismicidade no Nordeste Oriental Brasileiro: Revista Brasileira deGeociências, v. 19, no. 3, p. 310-320.

Ferreira, J.M., Takeya, M.K., Costa, J.M., Moreira, J.A.M., Assumpção, M., Veloso, J.A.V., and Pearce, R.G., 1987, A continuing intraplate earthquake sequence near João Câmara, NE Brazil-Preliminary results: Geophysical Research Letters, v. 14, p. 1042-1045.

Ferreira, J.M., Oliveira, R.T., Assumpção, M., Moreira, J.A.M., Pearce, R.G., andTakeya, M.K., 1995, Conrrelation of seismicity and water level in the Açu reservoir-An example from Northeast Brazil: Bulletin of the Seismological Society of America, v. 85, p. 1483-1489.

Ferreira, J.M., Oliveira, R.T., Takeya, M.K., and Assumpção, M., 1998, Superposition of local and regional stresses in northeast Brazil-Evidence from focal mechanisms around the Potiguar marginal basin: Geophysical Journal International, v. 134, p. 341-355. 
Fonseca, V. P., e Saadi, A., 1995, Compartimentos morfotectônicos no baixo curso do Rio açu (Açu-Macau), Rio Grande do Norte, in Simpósio de Geologia do Nordeste, 16, Recife, 1995: Boletim Sociedade Brasileira de Geologia, Recife-PE, v. 14 , no. 1 , p. $172-176$.

Fonseca, V.P., 1996, Estudos morfo-neotectônicos na área do Baixo Curso do Rio Açu (Açu-Macau)-Rio Grande do Norte: Belo Horizonte-MG, Universidade Federal de Minas Gerais (UFMG), Instituto de Geociências, Dissertação de Mestrado (Inédito).

Fonseca, V.P., 1997, Copartimento litorâneo entre Ponta do Mel e Ponta dos Três Inmãos, litoral norte do Rio Grande do Norte, in Symposium of Geology of Northeast Brazil: Sociedade Brasileria de Geologica, Frotaleza, Brazil, p. 174176.

Lima, C.C., Viviers, M.C., Moura, J.R.S., Santos, A.A.M., e Carmo, I.O., 1990, O Grupo Barreiras na Bacia Potiguar-Relações entre o padrão de afloramento, estruturas pré-Barreiras e neotectonismo, in Congresso Brasileiro de Geologia, 36, Natal, 1990: Anais Sociedade Brasileira de Geologia, Natal-RN, v. 2, p. 607-620.

Lima, C., Nascimento, E., and Assumpção, M., 1997, Stress orientations in Brazilian sedimentary basins from breakout analysis-Implication for force models in the South American plate: Geophysica Journal International, v. 130, p. 112-124.

Miranda, F.M., e Srivastava, N.K., 1984, Evidências de reativações tectônicas quaternárias na área de Macauzinho, estuário do Rio Açu no litoral norte do Rio Grande do Norte, in Impósio de Geologia do Nordeste, 11, Natal, 1984: Anais Sociedade Brasileira de Geologia, Natal-RN, v. 1, pp.157-164.

Oliveira, D.C., Matos, R.M.D., e Soares, U.M., 1993, Contribuição ao estudo das estruturas rasas na Bacia Potiguar-Análise estrutural do afloramento de Afonso bezerra (RN) e adjacências,in Simpósio Nacional de Estudos Tectônicos, 4, Belo Horizonte: Anais Sociedade Brasileira de Geologia, Belo Horizonte-MG, v. 1, p. 306-311.

Salim, J., Lima, M.S., e Mabesoone, J.M., 1979, Vales estruturais no litoral leste do Rio Grande do Norte: Boletim do Núcleo de Geologia do Nordeste, v. 4, p. 41-47.

Silva, C.G., 1992, Estratigrafia e evolução holocênica do Delta do Rio Açu, Bacia Potiguar, RN: Rio de Janeiro, Boletim de Geociências da PETROBRÁS, v. 6, no. 3/4, p. 242-243.

Torres, H.H.F., Barbosa, A.G., Braga, A.P.G., Gallardo, C., Sato, E.Y., e Mendonça, J.C.S., 1990, Projeto João Câmara-Estudos de neotectônica na Bacia Potiguar e adjacências, Relatório final: Convênio DNPM/CPRM Sureg Recife, 75 p. and anexos.(Inédito).

\section{BR-38, SAMAMBAIA FAULT}

FAULT NUMBER: BR-38

Comments: Shown as fault RGN-02 on initial compilation.

FAULT NAME: Samambaia

SYNOPSIS AND GEOLOGIC SETTING: The Samambaia fault is located within the Potiguar Basin (state of Rio Grande do Norte). It is a sedimentary basin that was formed during the Mesozoic fragmentation of Gondwana. Southern limit of fault is the Lajes lineament (BR-40).

COMPILER AFFILIATION, AND DATE OF COMPILATION: Vanildo Pereira da Fonseca (Univ. Federal do Rio Grande do Norte) and Allaoua Saadi (Univ. Federal de Minas Gerais, Belo Horizonte, Brasil), March 1997.

TYPE OF STUDIES: Geological and geomorphological studies based on interpretation of aerial photos and Landsat images, and field data.

FAULT GEOMETRY

LENGTH: $68.9 \mathrm{~km}$ end to end ( $68.7 \mathrm{~km}$ cumulative)

END POINTS: $5^{\circ} 15^{\prime} 59^{\prime \prime}$ S., $35^{\circ} 22^{\prime} 36^{\prime \prime}$ W.; 5 $44^{\prime} 14^{\prime \prime}$ S., $35^{\circ} 46^{\prime} 45^{\prime \prime} \mathrm{W}$.

AVERAGE STRIKE: $41^{\circ}$

AVERAGE DIP: $70^{\circ}$

SENSE OF MOVEMENT: Right lateral (dextral) strike-slip with normal component. 
Comments: Fault is well known from seismic activity (seismic events near João Câmara). Focal mechanism solution has $220^{\circ}$ strike $\left(\mathrm{S} 40^{\circ} \mathrm{W}\right), 70^{\circ} \mathrm{SE}$ dip, and $201^{\circ} \operatorname{slip}\left(\mathrm{S} 21^{\circ} \mathrm{W}\right)$.

GEOMORPHIC EXPRESSION: Nothing notable.

RECURRENCE INTERVAL: Unknown

SLIP RATE: Unknown, probably $<1 \mathrm{~mm} / \mathrm{yr}$.

TIME OF MOST RECENT OF MOVEMENT: Quaternary (<1.6 Ma)

Comments: There is no clear morphological evidence of surficial ruptures as an unpublished M.S. study has shown. Fault has been seismically active in historic time (microseismicity) based on several seismic events in the past few years (see Ferriera and others, 1987, 1998; Takeya and others, 1989).

HISTORICAL SURFACE FAULTING: None reported

NAME OF EARTHQUAKE: João Câmara-RN

DATE: Last important event on 30/11/96.

MAGNITUDE OR INTENSITY: Mb 5.1

\section{REFERENCES}

Assumpção, M., Suarez, G., and Veloso, J.A., 1985, Fault plane solutions of intraplate earthquakes in Brazil—Some constraints on the regional stress field: Tectonophysics, v. 113, p. 283-293.

Berrocal, J., Barros, J., e Oliveira, R., 1971, Sismotectônica do Nordeste Brasileiro, in Congresso Brasileiro de Geologia, 25, São Paulo, 1971: Anais Sociedade Brasileira de Geologia, São Paulo-SP, v. 2, p. 129-137.

Carneiro, C.D.R., Hamza, V.M., e Almeida, F.F.M. de, 1989, Ativação tectônica, fluxo geotérmico e sismicidade no Nordeste Oriental Brasileiro: Revista Brasileira deGeociências, v. 19, no. 3, p. 310-320.

Ferreira, J.M., Takeya, M.K., Costa, J.M., Moreira, J.A.M., Assumpção, M., Veloso, J.A., and Pearce, R.G., 1987, A continuing intraplate earthquake sequence near João Câmara, Northeastern Brazil—Preliminary results: Geophysical Research Letters, v. 14, no. 10, p. 1042-1045.

Ferreira, J.M., Oliveira, R.T., Takeya, M.K., and Assumpção, M., 1998, Superposition of local and regional stresses in northeast Brazil-Evidence from focal mechanisms around the Potiguar marginal basin: Geophysical Journal International, v. 134, p. 341-355.

Lima, C.C., Viviers, M.C., Moura, J.R.S., Santos, A.A.M., e Carmo, I.O., 1990, O Grupo Barreiras na Bacia Potiguar-Relações entre o padrão de afloramento, estruturas pré-Barreiras e neotectonismo, in Congresso Brasileiro de Geologia, 36, Natal, 1990: Anais Sociedade Brasileira de Geologia, Natal-RN, v. 2, p. 607-620.

Salim, J., Lima, M.S., e Mabesoone, J.M., 1979, Vales estruturais no litoral leste do Rio Grande do Norte: Boletim do Núcleo de Geologia do Nordeste, v. 4, p. 41-47.

Takeya, M., Ferreira, J.M., Pearce, R.G., Assumpção, M., Costa, J.M., e Sophia, C.M., 1989, The 1986-1988 intraplate earthquake sequence near João Câmara, NE Brazil-Evolution of seismicity: Tectonophysics, v. 167, p. 117-131.

Torres, H.H.F., Barbosa, A.G., Braga, A.P.G., Gallardo, C., Sato, E.Y., e Mendonça, J.C.S., 1990, Projeto João Câmara-Estudos de neotectônica na Bacia Potiguar e adjacências, Relatório final: Convênio DNPM/CPRM Sureg Recife, 75 p. y anexos (Inédito).

\section{BR-39, POTENGI FAULT}

FAULT NUMBER: BR-39

Comments: Shown as fault RGN-03 on initial compilation.

FAULT NAME: Potengi (fault)

SYNOPSIS AND GEOLOGIC SETTING: The Potengi fault is on the south side of the flood plain of the Potengi River, which drains into the Atlantic Ocean near the city of Natal-RN. The geological context is defined by 
Tertiary sedimentary rocks (Barreiras Group) that cover Neoproterozoic granites. The young fault is a result of reactivation of a Precambrian shear zone; it forms the southern border of the Potengi Graben. It is probably of Quaternary age because it displaces Tertiary sedimentary rocks (Bezerra and others, 1993, 1996).

COMPILER AFFILIATION, AND DATE OF COMPILATION: Vanildo Pereira da Fonseca (Univ. Federal do Rio Grande do Norte) and Allaoua Saadi (Univ. Federal de Minas gerais, Belo Horizonte, Brasil); March 1997.

TYPE OF STUDIES: Geological and geomorphological field data, and interpretation of geophysical data (electroresistivity and gravimetry).

FAULT GEOMETRY

LENGTH: $84.8 \mathrm{~km}$ end to end (84.7 km cumulative)

END POINTS: $5^{\circ} 54^{\prime} 140^{\prime \prime}$ S., $35^{\circ} 3^{\prime} 7^{\prime \prime} \mathrm{W} . ; 6^{\circ} 2^{\prime} 54^{\prime \prime}$ S., $35^{\circ} 47^{\prime} 59^{\prime \prime} \mathrm{W}$.

AVERAGE STRIKE: $79^{\circ}$.

Comments: Bezerra and others (1993) reported an aveage strike of $60^{\circ}$.

AVERAGE DIP: Approximately $80^{\circ}$ to vertical

SENSE OF MOVEMENT: Probably strike-slip with normal component.

Comments: The lateral sense of motion is unknown.

GEOMORPHIC EXPRESSION: The scarp that is along the lower basin of the Potengi River is underlain by Tertiary sediment. There is an alignment of crests in the granitic area, and reorientation of the lower basin of the Potengi River characterized by an asymmetrical drainage network and swamps.

\section{RECURRENCE INTERVAL: Unknown}

SLIP RATE: Unknown, probably $<1 \mathrm{~mm} / \mathrm{yr}$.

TIME OF MOST RECENT OF MOVEMENT: Quaternary $(<1.6 \mathrm{Ma})$

\section{REFERENCES}

Assumpção, M., Suarez, G., and Veloso, J.A., 1985, Fault plane solutions of intraplate earthquakes in Brazil—Some constraints on the regional stress field: Tectonophysics, v. 113, p. 283-293.

Berrocal, J., Barros, J., e Oliveira, R., 1971, Sismotectônica do Nordeste Brasileiro, in Congresso Brasileiro de Geologia, 25, São Paulo, 1971: Anais Sociedade Brasileira de Geologia, São Paulo-SP, v. 2, p. 129-137.

Bezerra, F.H.R., Saadi, A., Moreira, J.A.M., Lins, F.A.P.L., Nogueira, A.M.B., Macedo, J.W.P., Lucena, L.F., e Nazaré Jr., D., 1993, Estruturação neotectônica do litoral de Natal-RN, com base na correlação entre dados geológicos, geomorfológicos e gravimétricos, in Simpósio Nacional de Estudos Tectônicos, 4, Belo Horizonte, 1993: Anais Sociedade Brasileira de Geologia, Belo Horizonte-MG, v. 12, p. 317-321.

Bezerra, F.H.R.,Jardim de Sá, E.F., Saadi, A., e Fonseca, V.P., 1996, Falhas neotectônicas nos granitos da região de Macaíba, RN., in Congresso Brasileiro de Geologia, 39, Salvador, 1996: Anais Sociedade Brasileira de Geologia, Salvador-BA, v. 5, p. 464-467.

Salim, J., Lima, M.S., e Mabesoone, J.M., 1979, Vales estruturais no litoral leste do Rio Grande do Norte: Boletim do Núcleo de Geologia do Nordeste, v. 4, p. 41-47.

Torres, H.H.F., Barbosa, A.G., Braga, A.P.G., Gallardo, C., Sato, E.Y., e Mendonça, J.C.S., 1990, Projeto João Câmara-Estudos de neotectônica na Bacia Potiguar e adjacências, Relatório final: Convênio DNPM/CPRM Sureg Recife, 75 p. y anexos (Inédito).

\section{BR-40, LAJES LINEAMENT}

FAULT NUMBER: BR-40

Comments: Shown as fault RGN-04 on initial compilation.

FAULT NAME: Lajes (lineament) 
SYNOPSIS AND GEOLOGIC SETTING: The Lajes lineament is located on the south margin of the Potiguar Basin (sedimentary basin of Mesozoic age). It is within Precambrian basement rocks and has controlled the intrusion of Jurassic-Cretaceous magmatic dikes. Oliveira and Gomes (1996) describd hybrid fractures, cataclastic rocks, and gouge zones in the Ceará Mirim dike swarm, which represent reactivation processes at very shallow depth. Sykes (1978) was the first to link the distribution of intraplate earthquakes with that of igneous rocks that postdate Cretaceous rifting in NE Brazil, including the Lajes lineament.

COMPILER AFFILIATION, AND DATE OF COMPILATION: Vanildo Pereira da Fonseca (Univ. Federal do Rio Grande do Norte) and Allaoua Saadi (Univ. Federal de Minas gerais, Belo Horizonte, Brasil), March 1997.

TYPE OF STUDIES: Analysis of satellite and radar images, and compilation of geological and geomorphological information.

\section{FAULT GEOMETRY}

LENGTH: $263.5 \mathrm{~km}$ end to end (263.1 km cumulative)

END POINTS: $5^{\circ} 42^{\prime} 13^{\prime \prime}$ S., $35^{\circ} 28^{\prime} 00^{\prime \prime}$ W.; $5^{\circ} 50^{\prime} 42^{\prime \prime}$ S., $37^{\circ} 49^{\prime} 13^{\prime \prime} \mathrm{W}$.

AVERAGE STRIKE: $87^{\circ}$

Comments: En echelon fault zone.

AVERAGE DIP: Unknown

SENSE OF MOVEMENT: Right lateral (dextral) strike-slip

Comments: The movement was inferred from the regional neotectonic setting.

GEOMORPHIC EXPRESSION: Fault controls deflections of several stream channels. The fault has a continuous E-W scarp and controls the extent of the Mesozoic rocks of the Potiguar Basin.

RECURRENCE INTERVAL: Unknown

SLIP RATE: Unknown, probably $<1 \mathrm{~mm} / \mathrm{yr}$.

TIME OF MOST RECENT OF MOVEMENT: Quaternary $(<1.6 \mathrm{Ma})$

\section{REFERENCES}

Assumpção, M., Suarez, G., and Veloso, J.A., 1985, Fault plane solutions of intraplate earthquakes in Brazil—Some constraints on the regional stress field: Tectonophysics, v. 113, p. 283-293.

Berrocal, J., Barros, J., e Oliveira, R., 1971, Sismotectônica do Nordeste Brasileiro, in Congresso Brasileiro de Geologia, 25, São Paulo, 1971: Anais Sociedade Brasileira de Geologia, São Paulo-SP, v. 2, p. 129-137.

Carneiro, C.D.R., Hamza, V.M., e Almeida, F.F.M. de, 1989, Ativação tectônica, fluxo geotérmico e sismicidade no Nordeste Oriental Brasileiro: Revista Brasileira deGeociências, v. 19, no. 3, p. 310-320.

Fonseca, V. P., e Saadi, A., 1995, Compartimentos morfotectônicos no baixo curso do Rio açu (Açu-Macau), Rio Grande do Norte, in Simpósio de Geologia do Nordeste, 16, Recife, 1995: Boletim Sociedade Brasileira de Geologia, Recife-PE, v. 14, no. 1, p. 172-176.

Fonseca, V.P., 1996, Estudos morfo-neotectônicos na área do Baixo Curso do Rio Açu (Açu-Macau)-Rio Grande do Norte: Belo Horizonte-MG, Universidade Federal de Minas Gerais, Instituto de Geociências, Dissertação de Mestrado (Inédito).

Oliveira, D.C., and Gomes,C.J.S.,1996, The post-intrusion fault reactivation of the Rio Ceará Mirim dike swarm (Mesozoic)_Its implications for Potiguar basin tectonic evolution: Boletim de Geociências da Petrobrás, v. 10, no. 1/4, p. 121-145.

Poppof, M.,1988, Du Gondwana à l'atlantique Sud—Les connexios do Fossé de la Bénoué avec les bassins du Nord-Est brésilien jusqu'à l'ouverture du Golfe de Guinée au Crétacé inférieur: Journal of African Earth Sciences, v.7, no. 2, p. 409-431.

Silva, C.G., 1992, Estratigrafia e evolução holocênica do Delta do Rio Açu, Bacia Potiguar, RN: Boletim de Geociências da Petrobrás, Rio de Janeiro, v. 6, no. 3/4, p. 242-243.

Sykes, L.R., 1987, Intraplate seismicity, reactivation of preexisting zones of weakness, alkaline magmatism, and other tectonism postdating continental fragmentation: Review of Geophysical Space Physics, v. 16, p. 621-688. 
Torres, H.H.F., Barbosa, A.G., Braga, A.P.G., Gallardo, C., Sato, E.Y., e Mendonça, J.C.S., 1990, Projeto João Câmara-Estudos de neotectônica na Bacia Potiguar e adjacências, Relatório final: Convênio DNPM/CPRM Sureg Recife, 75 p. y anexos.(Inédito).

\section{BR-41, PELOTAS FAULT}

FAULT NUMBER: BR-41

Comments: Shown as fault RGS-01 on initial compilation.

FAULT NAME: Pelotas (fault)

SYNOPSIS AND GEOLOGIC SETTING: The Pelotas fault is located in southern Brazil, near the coast of the state of Rio Grande do Sul. It establishes the limit between the Precambrian basement rocks related to the Ribeira Fold Belt (on the west), which was active during the Brasiliano Orogenesis, and Cenozoic sediment of the Pelotas Basin (on the east). Presently, there are depressed zones along the fault in the Pelotas Basin that are occupied by a system of lakes—principally "Lagoa dos Patos" and "Lagoa Mirim."

COMPILER AFFILIATION, AND DATE OF COMPILATION: Allaoua Saadi (Univ. Federal de Minas Gerais, Belo Horizonte, Brasil) March 1997.

TYPE OF STUDIES: Interpretation of cartographic data and remote sensing images, in addition to regional field data.

FAULT GEOMETRY

LENGTH: $477.9 \mathrm{~km}$ end to end (479.2 $\mathrm{km}$ cumulative)

END POINTS: $30^{\circ} 10^{\prime} 57^{\prime \prime}$ S., $50^{\circ} 42^{\prime} 22^{\prime \prime} \mathrm{W}$.; $33^{\circ} 7^{\prime} 10^{\prime \prime} \mathrm{S}, 53^{\circ} 17^{\prime} 00^{\prime \prime} \mathrm{W}$.

AVERAGE STRIKE: $37^{\circ}$

Comments: Fault alignment has perfect continuity with the main scarp of the eastern border of the Paraná Basin to south and the scarp of the "Serra Geral" to the north.

AVERAGE DIP: Probably subvertical.

SENSE OF MOVEMENT: Probably strike-slip with vertical component

Comments: Geomorphology and structural geology suggest vertical component is down to the southeast.

However, there is no published information that is considered reliable.

GEOMORPHIC EXPRESSION: Forms a clear step between the crystalline (intrusive rock) plateau of Rio Grande do Sul and the coastal depression of the "Lagoa dos Patos".

RECURRENCE INTERVAL: Unknown

SLIP RATE: Unknown, probably $<1 \mathrm{~mm} / \mathrm{yr}$.

TIME OF MOST RECENT OF MOVEMENT: Quaternary $(<1.6 \mathrm{Ma})$

\section{REFERENCES}

Cecarelli, I.C.F., 1996, Evidências de feições neotectônicas na Província Costeira do Rio Grande do Sul, identificadas em imagens Landsat, in Congresso Brasileiro de Geologia, 39, Salvador, 1996: Anais Sociedade Brasileira de Geologia, Salvador-BA, v. 5, p. 467-470.

Saadi, A., 1993, Neotectônica da Plataforma Brasileira-Esboço e interpretação preliminares: Geonomos, Belo HorizonteMG, v. 1, no. 1, p. 1-15.

Villwock, J.A., (Coord.), 1992, Mapa geológico da Província Costeira do Rio Grande do Sul, in Congresso Brasileiro de Geologia, 37, São Paulo, 1992: Anais Sociedade Brasileira de Geologia, São Paulo-SP, v. 1, p. 85-86, escala $1: 1,000,000$. 


\section{BR-42, ALÉM PARAÍBA FAULT ZONE}

FAULT NUMBER: BR-42

Comments: Shown as fault RIO-01 on initial compilation.

FAULT NAME: Além Paraíba (fault zone)

SYNOPSIS AND GEOLOGIC SETTING: The Além Paraíba fault zone is part of the shear belts that were formed during the Precambrian and reactivated in the Neoproterozoic when they were associated with fold belts related to the Brasiliano Orogenesis in the Southeast Brazil. The fault zone is in the frontier area between the states of Minas Gerais and Rio de Janeiro, in the area of the Ribeira fold belt. Its Cenozoic reactivation was marked by the Eocene formation of the"Serra do Mar" rift system (Almeida 1976, Riccomini 1989), which controls the Volta Redonda Basin, a local graben.

COMPILER AFFILIATION, AND DATE OF COMPILATION: Allaoua Saadi (Univ. Federal de Minas Gerais, Belo Horizonte, Brasil), March 1997.

TYPE OF STUDIES: Compilation of cartographic and bibliographic data, and field data.

\section{FAULT GEOMETRY}

LENGTH: $404.6 \mathrm{~km}$ end to end (404.7 km cumulative)

END POINTS: $21^{\circ} 14^{\prime} 52^{\prime \prime} \mathrm{S}, 40^{\circ} 40^{\prime} 18^{\prime \prime} \mathrm{W} . ; 2^{\circ} 36^{\prime} 45^{\prime \prime} \mathrm{S}, 43^{\circ} 59^{\prime} 57^{\prime \prime} \mathrm{W}$.

AVERAGE STRIKE: $66^{\circ}$

Comments: The coordinates and strike refer to the main trace of the fault.

AVERAGE DIP: Vertical

SENSE OF MOVEMENT: Main movement is probably strike-slip

Comments: This inference is not based on precise field observations; lateral sense of inferred movement unknown.

GEOMORPHIC EXPRESSION: Fault zone forms scarps, crests, linear and asymmetrical valleys (especially in the valley of Middle Paraíba do Sul River) and concentrated zones of mass movement. On its eastern margin, it controls the contact among geomorphologic regions such as the Serra da Mantiqueira and the Coastal Tablelands in the state of Espírito Santo.

\section{RECURRENCE INTERVAL: Unknown}

SLIP RATE: Unknown, probably $<1 \mathrm{~mm} / \mathrm{yr}$.

TIME OF MOST RECENT OF MOVEMENT: Quaternary (<1.6 Ma)

Comments: On the basis of modern seismicity and the geomorphological evolution of the area, fault activity could have continued into the Holocene. However, there is lack of specific studies to prove this speculation.

\section{REFERENCES}

Almeida, F.F.M. de, 1976, The System of continental rifts bordering the Santos Basin, Brazil: Anais da Academia Brasileira de Ciências, v. 48 (supl.), p. 15-26.

Melo, M. S., Riccomini, C., Hasui, Y., e Coimbra, A.M., 1986, Geologia e evolução do sistema de bacias tafrogênicas continentais do sudeste do Brasil: Revista Brasileira Geociências, v. 16, p. 193-201.

Riccomini, C., 1989, O Rift Continental do Sudeste do Brasil: Instituo de Geociência/Universidade de São Paulo, São Paulo Tese de Doutoramento, $256 \mathrm{pp}$.

Saadi, A., 1988, Unidade Hidrelétrica de Sapucaia (UHE Sapucaia)—Estudo morfodinâmico das encostas do Circuito Hidráulico do Aproveitamento de Sapucaia, Relatório Técnica da Fase de Viabilidade: Centrais Energéticas Furnas, Rio de Janeiro-RJ/Leme Engenharia, Belo Horizonte-MG (40 p., fig., mapas). 


\section{BR-43, RIO BRANCO FAULT ZONE}

FAULT NUMBER: BR-43

Comments: Shown as fault ROR-01 on initial compilation.

FAULT NAME: Rio Branco (fault zone)

SYNOPSIS AND GEOLOGIC SETTING: The fault zone of the Branco River is located in the northern end of the Brazilian Territory, in the state of Roraima (north of Amazônia). It affects Precambrian basement that is part of the Granulitic Belt of Central Guyana.

COMPILER AFFILIATION, AND DATE OF COMPILATION: Allaoua Saadi (Univ. Federal de Minas Gerais, Belo Horizonte, Brasil), March 1997.

TYPE OF STUDIES: Compilation of bibliographic and cartographic data.

\section{FAULT GEOMETRY}

LENGTH: $664.3 \mathrm{~km}$ end to end (669.8 km cumulative)

END POINTS: $4^{\circ} 37^{\prime} 49^{\prime \prime}$ N., $59^{\circ} 28^{\prime} 52^{\prime \prime} \mathrm{W} . ; 1^{\circ} 29^{\prime} 45^{\prime \prime}$ S., $61^{\circ} 45^{\prime} 50^{\prime \prime} \mathrm{W}$.

AVERAGE STRIKE: $22^{\circ}$

AVERAGE DIP: Unknown

SENSE OF MOVEMENT: Probably right lateral (dextral) strike-slip.

GEOMORPHIC EXPRESSION: Fault zone controls the Branco River valley, starting from the point of capture of the Ubaricuera River.

\section{RECURRENCE INTERVAL: Unknown}

SLIP RATE: Unknown, probably $<1 \mathrm{~mm} / \mathrm{yr}$.

TIME OF MOST RECENT OF MOVEMENT: Quaternary (<1.6 Ma)

\section{REFERENCES}

Barbosa, O., e Ramos, J.R.A., 1959, Território do Rio Branco: aspectos principais da geomorfologia, da geologia e das possibilidades minerais de sua zona setentrional: Boletim da Divisão de Geologia e Mineralogia, Rio de Janeiro, Boletim 196, 46 pp.

Bemerguy, R.L., e Sena Costa, J.B., 1991, Considerações sobre a evolução do sistema de drenagem da Amazônia e sua relação com o arcabouço tectônico-estrutural: Boletim do Museu Paraense Emílio Goeldi, Série Ciências da Terra, v. 3, p. 76-97.

Costa, J.B.S., e Costa, J.A.V., 1996, O quadro neotectônico da região nordeste do Estado de Roraima, in Simpósio de Geologia da Amazônia, 5, Belém, 1996: Anais Sociedade Brasileira de Geologia/Núcleo Norte, Belém-PA ,p. 284286.

Eiras, J.F., e Kinoshita, E.M., 1988, Evidências de movimentos transcorrentes na Bacia do Tacutu: Boletim de Geociências da PETROBRÁS, v. 2, no. 2/4, p. 193-208.

Franco, E.M.S., Del Arco, J.O., e Riveti, M., 1975, Geomorfologia da Folha NA.20-Boa Vista, NB.20-Roraima e parte da Folha NA.21-Tumucumaque, in Projeto Radambrasil: Levantamento de Recursos Naturais, v. 8, p. 139-182.

Mc Connell, R.B., 1968, Planation surfaces in Guyana: Geographical Journal, v .134, p. 506-520.

Schaefer, C., and Dalrymple, J., 1995, Landscape evolution in Roraima, North Amazonia: planation, paleosols and paleoclimates: Zeitschrift für Geomorphologie, Neue Folge, v. 39, no. 1, p. 1-28.

Sternberg, H.O., 1950, Vales tectônicos na planície amazônica: Revista Brasileira de Geografia, Rio de Janeiro, v. 12 , no. 4, p. 3-26. 
Sternberg, H.O., 1953, Sismicidade e morfologia na Amazônia Brasileira: Boletim Geográfico, v. 11, no. 117, p. 595600 .

\section{BR-44, CUBATÃO SHEAR ZONE}

FAULT NUMBER: BR-44

Comments: Shown as fault SPA-01 on initial compilation.

FAULT NAME: Cubatão (shear zone)

Comments: Named in IPT, 1987.

SYNOPSIS AND GEOLOGIC SETTING: The Cubatão shear zone was formed during the Proterozoic orogenesis with a parallel orientation to the coast of the state of São Paulo (Ribeira fold belt). However, its main activity was during upper Proterozoic to Cambrian-Ordovician time. The shear zone affects Precambrian rocks and the thin Cenozoic sedimentary cover.

COMPILER AFFILIATION, AND DATE OF COMPILATION: Allaoua Saadi (Univ. Federal de Minas Gerais, Belo Horizonte, Brasil); March 1997.

TYPE OF STUDIES: Compilation of information extracted from cartographic and bibliographic documents.

FAULT GEOMETRY

LENGTH: $385.9 \mathrm{~km}$ end to end (385.0 $\mathrm{km}$ cumulative)

END POINTS: $23^{\circ} 57^{\prime} 2^{\prime \prime}$ S., 46 41' 56" W.; $25^{\circ} 37^{\prime} 57^{\prime \prime}$ S., $49^{\circ} 38^{\prime} 6^{\prime \prime} \mathrm{W}$.

AVERAGE STRIKE: $58^{\circ}$

AVERAGE DIP: Subvertical

SENSE OF MOVEMENT: Left lateral (sinistral) strike-slip during the upper Pleistocene.

Comments: Sense determined from interpretation of Melo and others, 1990.

GEOMORPHIC EXPRESSION: Faults of the shear zone form scarps, alignment of crests, and control fluvial valleys.

RECURRENCE INTERVAL: Unknown

SLIP RATE: Unknown, probably $<1 \mathrm{~mm} / \mathrm{yr}$.

TIME OF MOST RECENT OF MOVEMENT: Quaternary (<1.6 Ma)

Comments: According to Melo and others (1989, 1990), associated thrust faults cut Pleistocene colluvial-alluvial deposits.

\section{REFERENCES}

IPT (Instituto de Pesquisas Tecnológicas do Estado de São Paulo), 1987, Geologia das Folhas Juquiá e Miracatu, Estado de São Paulo: São Paulo, Relatório IPT, p. 25371.

Melo, M.S., Fernandes, L.A., Coimbra, A.M., e Ramos, R.G.N, 1989. O Graben (Terciário?) de Sete Barras, Vale do Ribeira do Iguape, SP: Revista Brasileira de Geociências, v. 19, no. 2, p. 260-262.

Melo, M.S., Fernandes, L.A., e Coimbra, A.M., 1990, Evolução tectôno-sedimentar cenozóica do baixo vale do Rio Ribeira do Iguape, SP, in Congresso Brasileiro de Geologia, 36, Natal, 1990: Anais Sociedade Brasileira de Geologia, NatalRN, v. 5, p. 2,250-2,260.

\section{BR-45, GUAPIARA LINEAMENT}

FAULT NUMBER: BR-45

Comments: Name from Ferreira and others, 1981. Shown as fault SPA-02 on initial compilation.

FAULT NAME: Guapiara (linament) 
SYNOPSIS AND GEOLOGIC SETTING: The Guapiara lineament is an ancient fault zone about $25 \mathrm{~km}$ wide that was mainly active during the Mesozoic (according to Melo and others, 1990). It cuts structures formed during the Proterozoic Orogenesis (Ribeira Fold Belt) in the south of the state of São Paulo.

COMPILER AFFILIATION, AND DATE OF COMPILATION: Allaoua Saadi (Univ. Federal de Minas Gerais, Belo Horizonte, Brasil), March 1997.

TYPE OF STUDIES: Compilation of information extracted from cartographic and bibliographic data.

FAULT GEOMETRY

LENGTH: $675.3 \mathrm{~km}$ end to end (675.3 km cumulative)

END POINTS: $20^{\circ} 50^{\prime} 17^{\prime \prime}$ S., $51^{\circ} 26^{\prime} 34^{\prime \prime} \mathrm{W}$.; $25^{\circ} 24^{\prime} 47^{\prime \prime}$ S., $47^{\circ} 56^{\prime} 03^{\prime \prime} \mathrm{W}$.

AVERAGE STRIKE: $-35^{\circ}$

AVERAGE DIP: Probably about $70^{\circ}$ NE

SENSE OF MOVEMENT: Normal

Comments: Result from WNW-ESE directed extension during the late Quaternary (Melo and others, 1990).

GEOMORPHIC EXPRESSION: Faults of the lineament for an alignment of scarps, NW-SE oriented depressions, and anomalies in the course of the Ribeira de Iguape River and its tributaries.

RECURRENCE INTERVAL: Unknown

SLIP RATE: Unknown, probably $<1 \mathrm{~mm} / \mathrm{yr}$.

TIME OF MOST RECENT OF MOVEMENT: Quaternary (<1.6 Ma)

Comments: The compilers information about the affected sedimentary deposits suggest that fault activity may have continued into the Holocene.

\section{REFERENCES}

Ferreira, P.J.F., Moraes, R.A.V., Ferrari, M.P., e Viana, R.B., 1981, Contribuição ao estudo do alinhamento estrutural de Guapiara, in Simpósio Regional de Geologia, 3, Curitiba, 1981: Anais Sociedade Brasileira de Geologia, Curitiba, MSP, v. 1, p. 226-240.

Melo, M.S., Fernandes, L.A., Coimbra, A.M., e Ramos, R.G.N, 1989. O Graben (Terciário ?) de Sete Barras, Vale do Ribeira do Iguape, SP: Revista Brasileira de Geociências, v. 19, no. 2, p. 260-262.

Melo, M.S., Fernandes, L.A., e Coimbra, A.M., 1990, Evolução tectôno-sedimentar cenozóica do baixo vale do Rio Ribeira do Iguape, SP, in Congresso Brasileiro de Geologia, 36, Natal, 1990: Anais Sociedade Brasileira de Geologia, NatalRN, v. 5, p. 2,250-2,260.

\section{BR-46, RIO PARAÍBA DO SUL CRUSTAL DISCONTINUITY (DCRPS)}

FAULT NUMBER: BR-46|

Comments: Shown as fault SPA-03 on initial compilation.

FAULT NAME: Rio Paraíba do Sul (crustal discontinuity)

Comments: Also known as DCRPS-Rio Paraíba do Sul crustal discontinuity (shear zone).

SYNOPSIS AND GEOLOGIC SETTING: The DCRPS is a shear zone that is part of the belts that were formed during the Precambrian. These belts were reactivated until the Neoproterozoic, when they were associated with fold belts that are built by the Brasiliano Orogenesis in Southeast Brazil. The DCRPS is in the frontier area between the states of Minas Gerais, São Paulo and Rio de Janeiro, in the domain of the Ribeira fold belt. Its Cenozoic reactivation was marked by the Eocene initiation of the"Serra do Mar" Rift System (Almeida 1976, Riccomini 1989), where it controlled the formation of most of the Tertiary basins, especially those of Resende and Taubaté. 
COMPILER AFFILIATION, AND DATE OF COMPILATION: Allaoua Saadi (Univ. Federal de Minas Gerais, Belo Horizonte, Brasil), March 1997.

TYPE OF STUDIES: Compilation of information extracted from cartographic and bibliographic documents and field data.

FAULT GEOMETRY

LENGTH: $396.6 \mathrm{~km}$ end to end (398.7 km cumulative)

END POINTS: $22^{\circ} 4^{\prime} 49^{\prime \prime}$ S., $43^{\circ} 22^{\prime} 58^{\prime \prime} \mathrm{W}$.; $23^{\circ} 47^{\prime} 22^{\prime \prime}$ S., $46^{\circ} 25^{\prime} 50^{\prime \prime} \mathrm{W}$.

AVERAGE STRIKE: $59^{\circ}$

Comments: Strike is for the main fault zone, situated to the north.

AVERAGE DIP: Probably vertical.

SENSE OF MOVEMENT: Right lateral (dextral) strike-slip with a vertical component

Comments: The several associated faults show alternate sense of movement.

GEOMORPHIC EXPRESSION: For the main fault there is a fault line scarp up to 2,000 $\mathrm{m}$ high, corresponding to the total Cenozoic throw in the longitude of the "Maciço do Itatiaia."

RECURRENCE INTERVAL: Unknown

SLIP RATE: Unknown, probably $<1 \mathrm{~mm} / \mathrm{yr}$.

TIME OF MOST RECENT OF MOVEMENT: Holocene and post glacial $(<15 \mathrm{ka})$

Comments: According to Riccomini and others (1989), some of these faults cut Holocene stone lines in colluvium.

\section{REFERENCES}

Almeida, F.F.M. de, 1976, The System of continental rifts bordering the Santos Basin, Brazil: Anais da Academia Brasileira de Ciências, v. 48 (suppl.), p. 15-26.

Fúlfaro, V.J., and Ponçano, W.L., 1974, Recent tectonic features in the Serra do Mar Region, State of São Paulo, Brazil, and its importance to engineering geology in International Congress of I.A.E.G., 2, São Paulo, 1974: Anais IAEG, São Paulo-SP, v. 1, p. II.7.1-II.7.7.

Fúlfaro, V.J., and Suguio, K., 1977, Vertical movements in continental southern Brazil during the Cenozoic, in N.A. Mörner (ed.), Earth rheology, isostasy and eustasy: John Wiley and Sons, p. 419-425.

Riccomini, C., 1989, O Rift Continental do Sudeste do Brasil: Instituo de Geociências/Universidade de São Paulo, São Paulo, Tese de Doutoramento, 256 pp.

Riccomini, C., Peloggia, A.U.G., Saloni, J.C.L., Kohnke, M.W., and Figueira, R.M., 1989, Neotectonic activity in the Serra do Mar Rift system (SE Brazil): Journal of South American Earth Sciences, v. 2, no. 2, p. 191-192.

\section{BR-47, MANGA FAULT}

FAULT NUMBER: BR-47

Comments: Shown as fault MGE-08 on initial compilation.

FAULT NAME: Manga (fault)

SYNOPSIS AND GEOLOGIC SETTING: The Manga fault lies in the axis of the São Francisco River valley, in the northern part of the state of Minas Gerais. It cuts Neoproterozoic pelitic-carbonatic metasediments that cover the Archean granitic-gneissic basement of the São Francisco Craton.

COMPILER AFFILIATION, AND DATE OF COMPILATION: Allaoua Saadi (Univ. Federal de Minas Gerais, Belo Horizonte, Brasil), March 1997.

TYPE OF STUDIES: Morpho-neotectonic analysis with field data. 
FAULT GEOMETRY

LENGTH: $256.4 \mathrm{~km}$ end to end ( $256.5 \mathrm{~km}$ cumulative)

END POINTS: $12^{\circ} 43^{\prime} 32^{\prime \prime}$ S., $43^{\circ} 12^{\prime} 02^{\prime \prime} \mathrm{W} . ; 4^{\circ} 50^{\prime} 30^{\prime \prime}$ S., $43^{\circ} 59^{\prime} 11^{\prime \prime} \mathrm{W}$.

AVERAGE STRIKE: $20^{\circ}$

AVERAGE DIP: $65^{\circ} \mathrm{E}$.

SENSE OF MOVEMENT: Reverse

Comments: Reverse component is considered to be east over west based on focal-mechanism determination from earthquake of 1990 (Veloso and others, 1990), which is compatible with regional morpho-neotectonic interpretation (Saadi, 1991).

GEOMORPHIC EXPRESSION: Fault controls linear course of the São Francisco River flood plain between the towns of Januária-MG and Paratinga-BA.

RECURRENCE INTERVAL: Unknown

SLIP RATE: Unknown, probably $<1 \mathrm{~mm} / \mathrm{yr}$.

TIME OF MOST RECENT OF MOVEMENT: Quaternary (<1.6 Ma)

Comments: May be historically active based on seismicity.

HISTORICAL SURFACE FAULTING: None reported.

NAME OF EARTHQUAKE: Manga-MG

DATE: March 1, 1990.

MAGNITUDE OR INTENSITY: Intensity IV MM.

\section{REFERENCES}

Saadi, A., 1991, Ensaio sobre a morfotectônica de Minas Gerais-Tensões Intraplaca, Descontinuidades Crustais e Morfogênese, Belo Horizonte-MG: Universidade Federal de Minas Gerais, Instituto de Geociências, Tese para admissão a cargo de Professor Titular (inédito).

Saadi, A., 1993, Neotectônica e tectônica recorrente na porção sul do Cráton do São Francisco, in Simpósio Sobre o Cráton do São Francisco, 2, Salvador, 1993: Anais Sociedade Brasileira de Geologia, Salvador-BA, p. 230-232.

Saadi, A., 1995, Geomorfologia da Serra do Espinhaço em Minas Gerais e de suas margens: Geonomos, Belo Horizonte-MG, v. 3, no. 1, p. 41-63.

Veloso, J.A., Assumpção, M., Carvalho, J., Barbosa, J.R., Fontenele, D., Bassine, A., Gomes, I.P., Blum, M., and Ribeiro, R.K., 1990, Sismicidade recente nos estados de Minas Gerais e Bahia, in Workshop sobre Neotectônica e Sedimentação Continental Cenozóica No. Sudeste do Brasil, 1, Belo Horizonte, 1990: Boletim da Sociedade Brasileira de Geologia, Belo Horizonte-MG, no. 11, p. 57-61

\section{BR-48，BATÁ-CRUZEIRO FAULT}

FAULT NUMBER: BR-48

Comments: Shown as fault ACR-01 on initial compilation.

FAULT NAME: Batá-Cruzeiro

SYNOPSIS AND GEOLOGIC SETTING: The Batá-Cruzeiro fault is at the western limit of the Brazilian Territory in the western part of the state of Acre. It is in Cretaceous and Cenozoic rocks along the axis of the Intracratonic Amazonas Basin (Paleozoic-Mesozoic).

COMPILER AFFILIATION, AND DATE OF COMPILATION: Allaoua Saadi (Univ. Federal de Minas Gerais, Belo Horizonte, Brasil), March 1997.

TYPE OF STUDIES: Compilation of cartographic and bibliographic data. 
FAULT GEOMETRY

LENGTH: $310.8 \mathrm{~km}$ end to end ( $316.7 \mathrm{~km}$ cumulative)

END POINTS: $6^{\circ} 47^{\prime} 34^{\prime \prime}$ S., 73 19' 7" W.; 9²6' 58" S., 72 29' $26^{\prime \prime} \mathrm{W}$.

AVERAGE STRIKE: $-17^{\circ}$

Comments: The trace is sinuous.

AVERAGE DIP: Unknown angle to the west?

SENSE OF MOVEMENT: Reverse, west side up?.

GEOMORPHIC EXPRESSION: Fault causes conspicuous topographical convexities that influence the texture (grain size) and facies of Quaternary deposits and the organization of the drainage network corresponding to different generations of channels.

\section{RECURRENCE INTERVAL: Unknown}

SLIP RATE: Unknown, probably $<1 \mathrm{~mm} / \mathrm{yr}$.

TIME OF MOST RECENT OF MOVEMENT: Quaternary $(<1.6 \mathrm{Ma})$

Comments: Fault may have been active in the Holocene.

\section{REFERENCES}

Assumpção, M., Suarez, G., and Veloso, J.A., 1985, Fault plane solutions of intraplate earthquakes in Brazil—Some constraints on the regional stress field: Tectonophysics, v. 113, p. 283-293.

Barros, E.M., Alves, E.D. de O., Araújo, J.F.V., Lima, M.I.C. de, and Fernandes, C.A.C., 1978,Geologia das folhas SB/SC, 18 Javari/Contamana, in Congresso Brasileiro de Geologia, 30, Recife, 1978: Anais Sociedade Brasileira de Geologia, Recife-PE, v. 1, no. 1, p. 43-57.

Cunha, F.M.B. da, 1988, Controle tectônico-estrutural na hidrografia na região do Alto Amazonas, in Congresso Brasileiro de Geologia, 35, Bélem, 1988: Anais Sociedade Brasileira de Geologia, Belém-NO, v. 5, p. 2267-2273.

Cunha, F.M.B. da, 1991, Morfologia e neotectonismo do Rio Amazonas, in Simpósio de Geologia da Amazônia, 3, Belém, 1991: Anais Sociedade Brasileira de Geologia/Núcleo Norte, Belém-PA, p. 193-210.

Saadi, A., 1993, Neotectônica da Plataforma Brasileira-Esboço e interpretação preliminares: Geonomos, Belo HorizonteMG, v. 1, no. 1 , p. 1-15. 
TABLE 1. QUATERNARY FAULTS AND LINEAMENTS IN BRAZIL

(No structures have known slip rates, they are inferred to be $<1 \mathrm{~mm} / \mathrm{yr}$ )

\begin{tabular}{|c|c|c|c|}
\hline No. & Name of structure & Sense of movement & $\begin{array}{l}\text { Time of most } \\
\text { recent faulting }\end{array}$ \\
\hline BR-01 & $\begin{array}{l}\text { Propriá fault zone and lineament (zona de falha e } \\
\text { lineamento de Propriá) }\end{array}$ & Normal with strike slip & $\begin{array}{l}<1.6 \mathrm{Ma} \text { (possibly } \\
\text { Holocene) }\end{array}$ \\
\hline BR-02 & Amapá fault (falha de Amapá) & Normal & $<1.6 \mathrm{Ma}$ \\
\hline BR-03 & Eurinepé lineament (lineamento de Eurinepé) & Strike slip(?) with reverse & $\begin{array}{l}<1.6 \mathrm{Ma} \text { (possibly } \\
\text { Holocene) }\end{array}$ \\
\hline BR-04 & Lower Juruá fault zone (zona de falhas do Baixo Juruá) & Reverse with strike slip? & $<1.6 \mathrm{Ma}$ \\
\hline BR-05 & Codajás fault (falha de Codajás) & Reverse with strike slip? & $<15 \mathrm{ka}$ \\
\hline BR-06 & Rio Jutaí fault zone (zona de falhas do Rio Jutaí) & Reverse with strike slip? & $<1.6 \mathrm{Ma}$ \\
\hline BR-07 & Lower Coarí fault zone (zona de falhas do Baixo Coarí) & Reverse with strike slip? & $<1.6 \mathrm{Ma}$ \\
\hline BR-08 & Lower Purús fault zone (zona de falhas do Baixo Purús) & Reverse with strike slip? & $<1.6 \mathrm{Ma}$ \\
\hline BR-09 & Rio Madeira fault zone (zona de falhas do Rio Madeira) & Dextral? & $<1.6 \mathrm{Ma}$ \\
\hline BR-10 & Rio Negro fault "A" (falha de Rio Negro "A") & Normal & $\begin{array}{l}<1.6 \mathrm{Ma} \text { (possibly } \\
\text { Holocene) }\end{array}$ \\
\hline BR-11 & Barcelos fault (falha de Barcelos) & Normal & $\begin{array}{l}<1.6 \mathrm{Ma} \text { (possibly } \\
\text { Holocene) }\end{array}$ \\
\hline BR-12 & $\begin{array}{l}\text { Serra do Estrondo fault zone (zona de falhas da Serra do } \\
\text { Estrondo) }\end{array}$ & Normal? & $\begin{array}{l}<1.6 \mathrm{Ma} \text { (possibly } \\
\text { Holocene) }\end{array}$ \\
\hline BR-13 & Maragogipe fault (falha de Maragogipe) & Normal & $<15 \mathrm{ka}$ \\
\hline BR-14 & Pé de Serra fault (falha de Pé de Serra) & Normal & $<1.6 \mathrm{Ma}$ \\
\hline BR-15 & Sobral-Pedro II lineament (lineamento de Sobral-Pedro II) & Dextral? & $<15 \mathrm{ka}$ \\
\hline BR-16 & Jaguaribe lineament (lineamento de Jaguaribe) & Dextral? with normal & $<1.6 \mathrm{Ma}$ \\
\hline BR-17 & Farias Brito fault (falha de Farias Brito) & Dextral? & $<1.6 \mathrm{Ma}$ \\
\hline BR-18 & $\begin{array}{l}\text { Arneiroz-Senador Pompeu fault (falha de Arneiroz- } \\
\text { Senador Pompeu) }\end{array}$ & Dextral? & $<1.6 \mathrm{Ma}$ \\
\hline BR-19 & Porangatu fault zone (zona de falhas de Porangatu) & Dextral? & $\begin{array}{l}<1.6 \mathrm{Ma} \text { (possibly } \\
\text { Holocene) }\end{array}$ \\
\hline BR-20 & Gurupi fault (falha de Gurupi) & Normal & $<1.6 \mathrm{Ma}$ \\
\hline BR-21 & Sobradinho fault zone (zona de falhas de Sobradinho) & Normal & $<1.6 \mathrm{Ma}$ \\
\hline BR-22 & Coxim fault (falha de Coxim) & Normal? & $\begin{array}{l}<1.6 \mathrm{Ma} \\
\quad \text { (Holocene?) }\end{array}$ \\
\hline BR-23 & $\begin{array}{l}\text { Upper Grande crustal discontinuity (descontinuidade } \\
\text { crustal do Alto Grande) (DCAG) }\end{array}$ & Dextral & $<15 \mathrm{ka}$ \\
\hline
\end{tabular}


TABLE 1-CONTINUED. QUATERNARY FAULTS AND LINEAMENTS IN BRAZIL

(No structures have known slip rates, they are inferred to be $<1 \mathrm{~mm} / \mathrm{yr}$ )

\begin{tabular}{|c|c|c|c|}
\hline No. & Name of structure & Sense of movement & $\begin{array}{l}\text { Time of most } \\
\text { recent faulting }\end{array}$ \\
\hline BR-24 & Rio Araçuaí fault (falha de Rio Araçuaí) & $\begin{array}{l}\text { Normal? with strike-slip } \\
\text { (principle component) }\end{array}$ & $<1.6 \mathrm{Ma}$ \\
\hline BR-25 & $\begin{array}{l}\text { Upper Rio São Francisco crustal discontinuity } \\
\text { (descontinuidade crustal do Alto Rio São Francisco) } \\
\text { (DCARSF) }\end{array}$ & Dextral & $\begin{array}{l}<1.6 \mathrm{Ma} \\
\quad(\text { Holocene?) }\end{array}$ \\
\hline BR-26 & $\begin{array}{l}\text { Campo do Meio fault zone (zona de falhas de Campo do } \\
\text { Meio) }\end{array}$ & Sinsitral? & $<1.6 \mathrm{Ma}$ \\
\hline BR-27 & Caratinga fault (fahla de Caratinga) & Strike slip? with vertical & $<1.6 \mathrm{Ma}$ \\
\hline BR-28 & Estrela fault (fahla de Estrela) & Reverse? with strike slip & $<1.6 \mathrm{Ma}$ \\
\hline BR-29 & Cardeal Mota fault (falha de Cardeal Mota) & Reverse? & $<1.6 \mathrm{Ma}$ \\
\hline BR-30 & Lower Xingu fault (falha de Baixo Xingu) & Normal? & $<1.6 \mathrm{Ma}$ \\
\hline BR-31 & Macapá fault (falha de Macapá) & Dextral? with normal & $<15 \mathrm{ka}$ \\
\hline BR-32 & Monte Alegre fault (falha de Monte Alegre) & Dextral? with normal & $<1.6 \mathrm{Ma}$ \\
\hline BR-33 & Lower Trombetas fault (falha de Baixo Trombetas) & Normal & $<1.6 \mathrm{Ma}$ \\
\hline BR-34 & Lower Tapajós fault (falha de Baixo Tapajós) & Normal & $<1.6 \mathrm{Ma}$ \\
\hline BR-35 & Patos lineament (lineamento de Patos) & Dextral? & $<1.6 \mathrm{Ma}$ \\
\hline BR-36 & Pernambuco lineament (lineamento de Pernambuco) & Dextral? & $<1.6 \mathrm{Ma}$ \\
\hline BR-37 & Afonso Bezerra fault (falha de Afonso Bezerra) & Sinistral & $<15 \mathrm{ka}$ \\
\hline BR-38 & Samambaia fault (falha de Samambaia) & Dextral with normal & $\begin{array}{l}<1.6 \mathrm{Ma} \\
\quad \text { (historic?) }\end{array}$ \\
\hline BR-39 & Potengi fault (falha de Potengi) & Strike slip? with normal & $<1.6 \mathrm{Ma}$ \\
\hline BR-40 & Lajes lineament (lineamento de Lajes) & Dextral & $<1.6 \mathrm{Ma}$ \\
\hline BR-41 & Pelotas fault (falha de Pelotas) & Strike slip? with vertical & $<1.6 \mathrm{Ma}$ \\
\hline BR-42 & $\begin{array}{l}\text { Além Paraíba fault zone (zona de falhas de Além } \\
\text { Paraíba) }\end{array}$ & Strike slip? & $\begin{array}{l}<1.6 \mathrm{Ma} \\
\quad(\text { Holocene?) }\end{array}$ \\
\hline BR-43 & Rio Branco fault zone (zona de falhas do Rio Branco) & Dextral? & $<1.6 \mathrm{Ma}$ \\
\hline BR-44 & Cubatão shear zone (zona de cisalhamento de Cubatão) & Sinistral & $<1.6 \mathrm{Ma}$ \\
\hline BR-45 & Guapiara lineament (lineamento de Guapiara) & Normal & $\begin{array}{l}<1.6 \mathrm{Ma} \\
\quad \text { (Holocene?) }\end{array}$ \\
\hline BR-46 & $\begin{array}{l}\text { Rio Paraíba do Sul crustal discontinuity (descontin- } \\
\text { uidade crustal do Rio Paraíba do Sul) (DCRPS) }\end{array}$ & Dextral with vertical & $<15 \mathrm{ka}$ \\
\hline BR-47 & Manga fault (falha de Manga) & Reverse & $<1.6 \mathrm{Ma}$ \\
\hline BR-48 & Batá-Cruzeiro fault (falha de Batá-Cruzeiro) & Reverse & $\begin{array}{l}<1.6 \mathrm{Ma} \\
\quad \text { (Holocene?) }\end{array}$ \\
\hline
\end{tabular}


